\title{
Tabularia
}

\section{Topographical and Thematic Perspectives in the Latin Poetry of the First Anglo-Norman Kings}

Perspectives topographiques et thématiques de la poésie latine à l'époque des premiers rois anglo-normands

Prospettive tematiche e topografiche nella poesia latina all'epoca dei primi re anglo-normanni

\section{Roberto Angelini}

\section{(2) OpenEdition}

\section{Journals}

Electronic version

URL: http://journals.openedition.org/tabularia/3009

DOI: 10.4000/tabularia.3009

ISSN: $1630-7364$

\section{Publisher:}

CRAHAM - Centre Michel de Boüard, Presses universitaires de Caen

\section{Electronic reference}

Roberto Angelini, «Topographical and Thematic Perspectives in the Latin Poetry of the First AngloNorman Kings », Tabularia [Online], Autour de Serlon de Bayeux : la poésie normande aux XIe-XIIe siècles, Online since 10 September 2018, connection on 01 May 2019. URL : http:// journals.openedition.org/tabularia/3009; DOI : 10.4000/tabularia.3009 



\title{
Topographical and Thematic Perspectives in the Latin Poetry of the First Anglo-Norman Kings Perspectives topographiques et thématiques de la poésie latine à l'époque des premiers rois anglo-normands Prospettive tematiche e topografiche nella poesia latina all'epoca dei primi re anglo-normanni
}

\author{
Roberto ANGELINI \\ Società Internazionale per lo Studio del Medioevo Latino, Firenze \\ robertoangelini@tin.it
}

\begin{abstract}
:
This study deals with Norman poetry: it examines the authors, the texts, and especially the literary genres to which they belonged, in the period between the XIth and XIIth centuries. Following a chronological order, the analysis starts from XIth-century Normandy: the main political and religious centres, Rouen, Caen and Le Bec, were also the most important places of poetic output. Most of these writings are hagiographies or encomia of important figures in the ducal and royal courts. In this regard, Serlo of Bayeux stands out as a clear example: his poems are valuable historical evidence for the Norman relationship with the English and their king in 1105-1106. In England, after the bold enterprise of William the Conqueror, Norman, Flemish, French and Italian learned men had a very important role in cultural life. York and Canterbury were the most prominent centres for versification. The study ends by focusing on the numerous verses contained in the historical works of Orderic Vitalis, William of Malmesbury and Henry of Huntingdon.
\end{abstract}

Keywords: medieval latin poetry, Rouen, Caen, Le Bec, hagiography, Epitaphia, Encomia poetica, Serlo of Bayeux, England, William the Conqueror, York, Canterbury, Orderic Vitalis, William of Malmesbury, Henry of Huntingdon

\section{Résumé:}

Cette étude traite de la poésie normande: elle examine les auteurs, les textes et surtout les genres littéraires auxquels ils appartiennent, aux XI et XII siècles. Suivant l'ordre chronologique, l'analyse commence à partir de la Normandie du XIe siècle. Les principaux centres politiques et religieux, Rouen, Caen et Le Bec, sont aussi les chefs-lieux de la production poétique. La plupart de ces écrits sont hagiographiques ou laudatifs de figures importantes dans les cours ducales et royales. À cet égard, Serlon de Bayeux se détache comme un exemple clair: ses poèmes sont une précieuse preuve historique de la relation normande avec les Anglais et leur roi en 1105-1106. En Angleterre, après l'audacieuse entreprise de Guillaume le Conquérant, les savants normands, flamands, français et italiens ont joué un rôle très important dans la vie culturelle. York et Cantorbéry étaient les centres les plus importants pour la versification. L'étude se termine en se concentrant sur les nombreux versets contenus dans les auvres historiques d'Orderic Vital, Guillaume de Malmesbury et Henri de Huntingdon.

Mots-clés: poésie latine médiévale, Rouen, Caen, Le Bec, hagiographie, Epitaphia, Encomia poetica, Serlon de Bayeux, Angleterre, Guillaume le Conquérant, York, Cantorbéry, Orderic Vital, Guillaume de Malmesbury, Henri de Huntingdon

Tabularia «Études», "Autour de Serlon de Bayeux... », 2018, p. 1-54, 10 septembre 2018 URL: http://journals.openedition.org/tabularia/3009 | DOI: 10.4000/tabularia.3009 
Riassunto:

Lo studio riguarda la poesia normanna: autori, testi, ma soprattutto i loro generi letterari, nel periodo tra XI e XII secolo. L'analisi procede a un esame in ordine cronologico, a partire dalla Normandia del Mille. I principali centri politici e religiosi, Rouen, Caen, Le Bec, furono allo stesso tempo capoluoghi di produzione poetica. In maggioranza i testi riguardano temi agiografici o encomiastici, rivolti alle più eminenti figure delle corti ducali e regali. A questo proposito, Serlo di Bayeux rappresenta un caso esemplare, con i suoi versi, circa le relazioni con gli Inglesi e il loro sovrano nel periodo tra 1105 e 1106. In Inghilterra, in particolare, dopo l'audace impresa di Guglielmo il Conquistatore, intellettuali normanni, fiamminghi, francesi e italiani ebbero un ruolo molto importante nella vita culturale britannica. York e Canterbury furono gli ambiti preminenti anche sotto il profilo della versificazione. Lo studio termina con un esame specifico dei numerosi carmi presenti nelle cronache di Orderico Vitale, Guglielmo di Malmesbury ed Enrico di Huntingdon.

Parole chiave: poesia latina medievale, Rouen, Caen, Le Bec, agiografica, Epithaphia, Encomia poetica, Serlo di Bayeux, Inghilterra, Guglielmo il Conquistatore, York, Canterbury, Orderico Vitale, Guglielmo di Malmesbury, Enrico di Huntingdon

I would like to thank Moreed Arbabzadah and Sandra Kahl Garcia for their precious help.

From the mid-tenth century the two sides of the English Channel forged a closer relationship, especially in conjunction with the insular Benedictine Reform ${ }^{1}$, which produced important figures such as Dunstan of Canterbury in Britain ${ }^{2}$. The respective insular and continental contributions in this cultural interchange ${ }^{3}$ reveal the equal importance of Anglo-Saxon scholars and counterparts from Flanders, Northern France, and particularly from the segment of Neustria acquired by the Viking Rollo ${ }^{4}$ and ruled by his heirs ${ }^{5}$. A witness of the literary connection in the first quarter of the eleventh century is Warner of Rouen ${ }^{6}$, who provides at least two and perhaps five remarkable satirical compositions ${ }^{7}$. The

1. KNOWLeS, 1949, p. 31-190.

2. Hunt, 1961; Dales, 1988; St Dunstan: His Life, Times and Cult, Ramsay, Sparks and TattonBrown (eds), 1992; LAPIDGE, 2004; LAPIDGE and Love, 2009.

3. RigG, 1992, p. 9.

4. Douglas, 1942; Jones, 1968, p. 229-232; MCKitTerick, 1983, p. 228-240; Crouch, 2002, p. 1-58; BAUDUIN, 2004.

5. LEBLOND, 1966, p. 179-187, 279-280; BATE, 2000.

6. Musset, 1954; LAPIDge, 1972, p. 101-102; Musset, 1974; MCDonough, 2002; Ferrari, 2006; Tilliette, 2012.

7. The most renowned of these poems is an invective, the so-called Moriuth, inc. "Rotberto domino subnixo praesulis ostro" (SCHALlER and KöNSGEN, 1977, no. 14391), from the name of the Irish opponent in the verse: 249 leonine elegiac couplets, ed. in OMONT, 1894, and WARNER OF Rouen, Moriuht. A Norman Latin Poem of the Early Eleventh Century, Chr.J. McDonough (ed.), p. 109-204. Cf. Schmidt, 1988; Wolterbeek, 1991, p. 192-218; Öberg, 1998; Dumville, 2002; McDonough, 2006. The second satire is the Carmen ad Rotbertum, inc.: "Rotberto doctis fulgenti semper alumnis" (SCHAller and Könsgen, 1977, no. 1439o): 8o leonine distichs, ed. in Musset, 1954, p. 259-266, and McDonough, 1997, p. 44-51. The first of the three dubious poems in hexameters is Iezebel, inc.: "Nomen ab Ie (Abie; ab te) sonat, Iaezabel quia corruit ah ah" (SCHALlER and Könsgen, 
Danish conquest in England marked a break, and from 1042 the restored rule of the half-Saxon, half-Norman King Edward the Confessor ${ }^{8}$ stands as a fresh start for the renewed, longer-term dialectic of exchange ${ }^{9}$. A considerable flow of religious scholars to Britain began from Normandy to overseas monastic homes. After the battle of Hastings this movement was overcome by a systematic Norman transformation of the Island.

In fact, since 1066, William the Conqueror ${ }^{10}$ had begun the complete occupation of the leading centres of power, not only from a military and political point of view. The more than thirty English abbeys under his reign were progressively filled and ruled by monks from the other side of the Channel ${ }^{11}$; the new king normanized every diocesan see, especially the prominent ones, which in turn remained vacant, by appointing to them the most prestigious figures not only of the clergy, but also of culture in the Duchy, where in fact the intellectual atmosphere was livelier than one could expect.

In the second half of the eleventh century, Rouen seems to have been the principal centre, and this was not only due to its role as a political capital. It was in fact the pivot of a more complex and articulated circulation of written production. As for poetry, there was a clear distinction of literary themes and schemes among the respective religious institutions of the town, although it is possible to recognize some well-defined shared tendencies. After the deposition of Mauger the cathedral chair ${ }^{12}$, which was once of Robert II (ca. 990-1037), had to be covered in 1055 by the high-profile figure of Maurilius (b. ca. 990, d. 9 August 1067) ${ }^{13}$. He was born in the last decade of the tenth century in Reims; although his origin was not Norman, he gathered such an international experience, through long stays in Halberstadt, Fécamp and, above all, in Tuscany (where he met renowned exponents of the Ecclesiastical Reform Party), that William the Conqueror appointed him to the prestigious position: this choice also soothed some recent grievances from the Apostolic See about his wedding with Matilda of Flanders ${ }^{14}$. In 1063, only three years before the Norman Conquest, a turning point in the growth of power (and wealth) for the ruling dynasty, the latter

1977, no. 10312; WALther, 1959, no. 11912), 142 lines: Jezebel. A Norman Latin Poem of the Early Eleventh Century, J.M. Ziolkowski (ed.), p. 65-78; on the same subject cf. van Houts, 1992; Galloway, 1999. The second uncertain text is Semiramis, inc.: "Fama puellaris tauri corrupitur extis” (SCHALler and KöNSGen, 1977, no. 4937; WALther, 1959, no. 6255): 181 leonine verses, ed. in Dronke, 1986, p. 66-113 [in particular, for the edition and English translation p. 66-75]; on this poem cf. Rico, 1973; van Houts, 1992; Archibald, 2001. There is one more piece of 76 hexameters, recently found in the ms Paris, BnF, nouv. acq. lat. 3232: cf. Bourgain, 2013, p. 103-107.

8. The Life of King Edward Who Rests at Westminster, Attributed to a Monk of Saint-Bertin, F. BARlow (ed.); BARlow, 1970; BARlow, 2004a; LAPIDGe, $2009 \mathrm{~b}$.

9. Southern, 1970, p. 135-157 [chapter 8: "England's First Entry into Europe"]; Fleming, 1985; FLEMING, 1991; RIGG, 1992, p. 9-12; for a different interpretation cf. ORTENBERG, 1992.

10. Stenton, 1908; Douglas, 1964; Zumthor, 1964; BARlow, 1965; JäSChKe, 1977; BoüARD, 1984; BATES, 2004b; LAPIDge, 2014b; BATES, 2016.

11. KNOWLES, 1949, p. 100-144.

12. Allen, 1995.

13. Boüard, 1959; Douglas, 1964, p. 121-122; Zumthor, 1964, p. 198-200.

14. Strickland, 1850, p. 17-78; Douglas, 1964, p. 393-395; van Houts, 2004. 
enjoyed a sort of return to its original roots: an authentic revival of Antiquitates Normannicae, so that the archbishop, who led the translatio corporum of the founders, Rollo and his son William Longsword ${ }^{15}$, in the cathedral, was also the author of the epitaphia for the two Viking jarls ${ }^{16}$.

In 1067, when Maurilius died, Richard, son of Herluin, wrote for him a short obituary verse, inscribed above the tomb ${ }^{17}$. Among the bishop's disciples, William Bona Anima ${ }^{18}$ was in many respects the most notable figure. Although the date of birth of this noble Norman is unknown, he flourished in the second half of the eleventh century (and died on February 9, 1110) under William the Conqueror's protection. Through his Rouen apprenticeship and ecclesiastical cursus honorum, he was in contact with some of the major centres (and personalities) of ducal power. In 1079 he therefore became archbishop of the city with the approval of the sovereign. It is regrettable that, despite his political relevance, the manuscript tradition has transmitted only a few works of his: not more than three letters ${ }^{19}$ and, so far as poetry is concerned, the epitaph ${ }^{20}$ for Sybil (died 18 March 1103), the wife of Robert Curthose ${ }^{21}$.

More prolific literary activity was undertaken not only in approximately the same period (starting from the 106os) but also in the environment of Rouen's cathedral by the canon Theobald, who was a native of Vernon, near Évreux. Unfortunately, his written output has for a long time been unclear $^{22}$ : there would have been a great deal of lost texts, including those in rhythmical verse and the vernacular, about ancient saints (for example Thais, Mary of Egypt, Catherine of Alexandria) or more recent figures (like Wulfram, Archbishop of Sens). In this regard, much doubt still exists, especially after the twentieth-century attribution to him of two acrostic allegorical poems ${ }^{23}$. At any rate, the core of his poetry

15. Douglas, 1942, p. 435; Crouch, 2002, p. 14, 41.

16. Both of the two poems, Epitaphia Rollonis et Guillelmi Longae Spathae, respectively inc.: "Dux Normannorum, timor hostis et arma suorum" and "Quos defendebat Guillelmus, nemo premebat" (WALTHER, 1959, nrr. 5037 and 16366), 10 and 7 leonine elegiac distichs, with monosyllabic or disyllabic rhyme, are transmitted by Orderic Vitalis, The Ecclesiastical History of Orderic Vitalis, M. Chibnall (ed.), book V, vol. III, p. 90-92.

17. The text, inc. "Humani cives lacrimam nolite negare": 4 distichs, is in The Ecclesiastical History of Orderic Vitalis, M. ChibNall (ed.), book IV, vol. II, p. 198.

18. Williams, George, 1951, p. 102-125; Spear, 1989; Spear, 1992, p. 56-57, 60; Watkins, 2006, p. 79-80, 90-93; ANGELINI and LAPIDGE, 2014.

19. Epistola ad Anselmum (dated 1093), ed. in EAdMeri Historia Novorum in Anglia, M. Rule (ed.), p. 38; two Epistolae ad Lambertum episcopum Atrebatensem: ed. in STEPHANi Baluzir miscellaneorum liber primus [-septimus], hoc est Collectio veterum monumentorum quae hactenus latuerant in variis codicibus ac bibliothecis, vol. V, 1700, p. 286 and 344 [reimpr. in Patrologia Latina (quoted infra: PL), vol. CLXII, 1854, col. 650 and 683-684].

20. The poem, inc.: "Nobilitas species, laus, gloria, magna potestas" (WALTHer, 1959, no. 11870): five distichs, transmitted by The Ecclesiastical History of Orderic Vitalis, M. CHIBNALL (ed.), book XI, vol. VI, p. 38-39; cf. van Houts, 1989, p. 46.

21. For Robert and Sybil, cf. David, 1920; Thompson, 2004; LACK, 2007; Aird, 2008.

22. Histoire littéraire de la France par des religieux bénédictins de la congrégation de S. Maur, vol. VII, 1746, p. 512-513, and vol. XIII, 1814, p. 112-114.

23. About the two poems cf. HerrmanN, 1940, p. 38-40: edition on the basis of the manuscript Bruxelles, Koninklijke Bibliotheek Van Belgie 8883-94. The titles, Iustorum mores lapides sunt 
consists in hagiography: three metrical biographies, in hundreds of rhymed lines, of Alexis the Confessor ${ }^{24}$, Theophilus Adanensis ${ }^{25}$ and Gummar ${ }^{26}$, although the last of these is still considered among the works whose attribution is doubtful ${ }^{27}$.

This kind of literary production leads to another centre of the religious and intellectual life of Rouen: the local abbey of Saint-Ouen ${ }^{28}$. Between 1042 and 1092, when Nicholas of Normandy ${ }^{29}$ was abbot, in this religious centre, where the poetic production was rich and intense ${ }^{30}$, almost all of the three main figures that are known dealt with hagiography: Theodoric ${ }^{31}$ composed the long Vita sancti Audoeni $i^{32}$, as well as the Gesta episcoporum Rotomagensium ${ }^{33}$; both of them were attributed also to Fulbert ${ }^{34}$, who lived a century later and actually compiled only a collection of Miracula ${ }^{35}$; little is known of Maurice, author of an epitaphium in

multi colores and Terra Creatoris sic vim scrutetur amoris, are formed by the initials of the verses, respectively: 36 rhymed hexameters, which give an interpretation of twelve kinds of stone; 35 leonine hexameters on mystic subjects.

24. Vita metrica sancti Alexii confessoris (in Bibliotheca Hagiographica Latina antiquae et mediae aetatis (BHL), Socii Bollandiani [eds], no. 293): 290 leonine hexameters, ed. in Acta Sanctorum quotquot toto orbe coluntur [AASS], J. Bolland, G. Henschenius et al. (eds), Iul., vol. IV, 1725, p. 254-256 [but cf. Herrmann, 1940, p. 30-32 for important ecdotic remarks and some observations about the mistaken attribution to Marbod of Rennes]; ed. also in WAGNER, 1973, p. 156-169.

25. Vita metrica sancti Theophili, vicedomini Adanensis (in $B H L$, no. 8124): 568 leonine hexameters, ed. in AASS, Febr., vol. I, 1658, p. 487-491; HERRMANN, 1940, p. 30 about the mistaken attribution to Marbod of Rennes.

26. Vita metrica sancti Gummari confessoris (in BHL, nrr. 3696-3697): 655 mostly leonine hexameters, ed. by Herrmann, 1939; Morel, 1940 [ecdotic remarks].

27. Cf. Bon, 2005, p. 235 for the most reliable list of authentic works. See furthermore the review by OrLANDI, 1973 against the attribution of this work to Theobald of Vernon.

28. Pommeraye, 1662; Bourassé, 1900, p. 277-287; Masson and Battle, 1927; Cottineau, 19351937, vol. II, col. 2547-2550; Chaline, 2009.

29. Pommeraye, 1662, p. 251-256; Histoire littéraire de la France, vol. VIII, 1747, p. 364 [reimpr. in $P L$, vol. CL, 1854, col. 1187-1189]. GAZEAU, 2007, vol. II, p. 244-248.

30. This is the opinion that has spread since Pommeraye, 1662, p. 337-341.

31. Ibid., p. 339; Histoire littéraire de la France, vol. VIII, 1747, p. 365 [reimpr. in PL, vol. CL, 1854, col. 1187-1189].

32. Vita metrica sancti Audoeni (in BHL, no. 754): 1128 hexameters, partially ed. in Neustria pia, seu de omnibus et singulis abbatiis et prioratibus totius Normaniae, A. Du Monstier (ed.), p. 23-24, 72-73, 346-347 [prologus, inc.: "Patri sincero tranquilla pace sereno" (WALTHER, 1959, no. 13831) and other two fragments; reimpr. in PL, vol. CL, 1854, col. 1189-1192]; cf. DolbeaU, 2003, p. 239-243, 250.

33. About this work, known also as Acta (sive Chronicon, sive Historia) episcoporum Rotomagensium, cf. Veterum analectorum tomus I, I, J. MABILlon (ed.), 1676, p. 424-455 [and, for the edition, Paris, $1723^{2}$, vol. II, p. 222-226]; Veterum scriptorum et monumentorum moralium, historicorum, dogmaticorum ad res ecclesiasticas, monasticas et politicas illustrandas collectio nova, E. MARTÈnE (ed.), 1700 , vol. I/2, p. 233-249 [the edition is assigned to an anonymous author of eleventh century]; Recueil des historiens des Gaules et de la France (= Rerum Gallicarum et Francicarum Scriptores), M. BouQUeT (ed.), 1739, p. 16-17 [edition of some excerpts]; Histoire littéraire de la France, vol. XI, 1759, p. xvi-xviii.

34. Pommeraye, 1662, p. 339-340; Histoire littéraire de la France, vol. VIII, 1747, p. 365 [reimpr. in PL, vol. CL, 1854, col. 1187-1189]; Annales Ordinis S. Benedicti, J. Mabillon (ed.), vol. I, 1739, p. 583; NoCENTINI, 2011

35. Miracula sancti Audoeni (in BHL, no. 76o), ed. in AASS, Aug., vol. IV, 1739, p. 625-637; cf. Musset, 1962, p. 132-133; van Houts, 2000, p. 88; Dolbeau, 2005, p. 750-751, n. 14, and 758-762; ToMEA, 2010, p. 476-478. 
obitu Nicholai de Normannia ${ }^{36}$ (a work which still insists on the local coenobitic tradition, even in the widely-practised obituary genre), beyond his name, since modern scholarship has confused named individuals with other distinguished monks belonging to the same regular institution. The mistake concerns a certain Ambrose and $\mathrm{John}^{37}$, who are identifiable with the most celebrated Milanese archbishop and the Neapolitan deacon, and who were both recognised (or supposed) writers of hagiographical works, on the Roman martyr Agnes ${ }^{38}$ and Nicholas of $\mathrm{Myra}^{39}$ respectively. The origin of the misunderstanding is a book: the famous 11th-first decade of 12th century Livre Noir, Rouen, Bibliothèque Municipale Y $41(1406)^{40}$, which gathers all of the above-mentioned texts (except the epitaph), together with many other anonymous sermons, narrative and rhymed prose, as well as verses (mainly hymns) about the most venerated personalities in the Norman monastery. Such manuscript evidence underlines the predominant interest in writing about saintly women, men and things.

Another monastic figure, Durand, had contact with the contemporary Rothomagensis environment but not the abbey of Saint-Ouen; he transgressed many boundaries, and not only geographical ones. Durand ${ }^{41}$ was born between 1005 and 1020 near Bayeux, but it was in Upper Normandy that he completed his education: after Saint-Wandrille de Fontenelle ${ }^{42}$, in Rouen, abbey of Mont-Sainte-Catherine (now Sainte-Trinité) ${ }^{43}$, his personal and ecclesiastical route led him far from the capital, first to Fécamp ${ }^{44}$ and then, starting from 1059, to the Lower part of the Duchy, to become the first abbot in the monastery that Roger Montgomery ${ }^{45}$ had recently founded: Saint-Martin de Troarn ${ }^{46}$. Under the name of Durandus Troarnensis there are two epitaphia: the older one ${ }^{47}$ is for Ainard, abbot of Notre-Dame de Saint-Pierre-sur-Dives until $1078^{48}$; the later ${ }^{49}$

36. In obitu Nicholai de Normannia, abbatis Sancti Audoeni Rotomagensis, inc.: "Hic amor et pietas, monachorum flos et honestas" (WALther, 1959, no. 7850): a leonine tetrastich, in Annales Ordinis S. Benedicti, Mabillon (ed.), vol. V, p. 276 [Liber LXVIII, n. xxxv; reimpr. in PL, vol. CLXXXVIII, 1855, col. 635]; cf. Pommeraye, Histoire de l'abbaye royale de S. Ouen de Rouen, p. 339-340. See reference in GAZEAU, 2007, vol. II, p. 245, n. 31.

37. Pommeraye, 1662, p. 339; Histoire littéraire de la France, vol. VIII, 1747, p. 365 [reimpr. in PL, vol. CL, 1854, col. 1187-1199].

38. BHL, no. 156 .

39. Ibid., no. 6104 .

40. DolbeAu, 2003, p. 239-243.

41. Heurtevent, 1912; Contini, 2009.

42. Gazeau, 2007, vol. II, p. 372-374.

43. Ibid.

44. Ibid.

45. Mason, John, 1963; Thompson, 1987; Chandler, 1989; Lewis, 1991; Mason, John, 2004 b.

46. GAZEAU, 2007, vol. II, p. 372-374.

47. Epitaphium in morte Ainardi Sancti Petri Divensis abbatis, inc.: "Hic iacet Ainardus redolens ut pistica nardus" (WALTHER, 1959, no. 7938): 7 leonine distichs, transmitted in The Ecclesiastical History of Orderic Vitalis, M. Chibnall (ed.), book IV, vol. II, p. 352.

48. GazeAu, 2007, vol. II, p. 299.

49. Epitaphium in morte Mabillae, Rogerii de Montgomery comitis uxoris, inc.: "Alta clarentum de stirpe creata parentum" (WALTHER, 1959, no. 842): 7 distichs (without rhyme), in The Ecclesiastical History of Orderic Vitalis, M. Chibnall (ed.), book V, vol. III, p. 136-138. 
one mourns the death, in 1079, of countess Mabile, the wife of the founder of the coenobium ${ }^{50}$. The major work by Durand is De corpore et sanguine Christi ${ }^{51}$, initially written in 1053-1054 in the form of a prose treatise and then, some years later (perhaps between 1055 and 1058), in verse ${ }^{52}$. It is the first confutation of the theological arguments of Berengar of Tours ${ }^{53}$ against the transubstantiation of bread and wine during the Eucharist. To overthrow such heterodox theses, the learned text by the Norman monk, which uses biblical and patristic quotations alongside examples of miracles, joins a well-known controversy involving the most eminent intellectuals of that time ${ }^{54}$.

An important figure in the controversy was Lanfranc of Pavia ${ }^{55}$. This scholar, as the main counsellor of William the Conqueror, played the key role of the royal intellectual counterpart: the first of several significant Italian contributions to open up new dynamic perspectives, even on the rule of monastic communities: from 1045 to 1063 in Le Bec ${ }^{56}$, then in the abbey of Saint-Étienne de Caen ${ }^{57}$, which he left after the Norman Conquest. In this period the former abbot moved with a great deal of learned monks to the other side of the Channel ${ }^{58}$, to reach and hold the metropolitan see of Canterbury from 1070 until 1089. This leading position is no less important than the entire literary production of the theologian ${ }^{59}$, who wrote, although it is little known, some verses on the canonical hours on the Ash Wednesday ${ }^{60}$.

Before leaving Lanfranc, the environment of his teaching (and governance) in Normandy still deserves a little attention, first of all because not every migrant

50. White, 1940, p. 86-88; Cokayne, 1949, p. 233, 683, 686-687, 689, 695, 762; Mason, John, 1963, p. 1-2; Douglas, 1964, p. 414; van Houts, 1988 [in particular Appendix 4]; Stafford, 1994, p. 227.

51. The text, transmitted by manuscript Paris, BnF, ms lat. 2720, bears the titles of Liber de corpore et sanguine Christi contra Berengarium et eius sectatores, but also Liber de corpore et sanguine Domini, in Beati Lanfranci Cantuariensis Archiepiscopi Opera omnia, L. d'Achery (ed.), Appendix, p. 72-107 [reimpr. in PL, vol. CXLIX, 1853, col. 1375-1424]; on this work cf. HeUrTevent, 1912, p. 217-251; MACDONALD, 1930, p. 121-122, 227, 277-284; D'ONOFrio, 1996, p. 451-452.

52. The whole text of De corpore et sanguine Christi, inc.: "Doctorum cunctos labor est inquirere libros" (WALTHER, 1959, no. 4678), amounts more than 900 hexameters in the manuscript Paris, BnF, ms lat. 2720; the only partial available editions are PL, vol. CXLIX, 1853, col. 1375 [25 verses of the Prologus] and Annales Ordinis S. Benedicti, J. MABILlon (ed.), vol. V, p. 103-104 [3 fragments, from an unidentifiable manuscript].

53. MacDonald, 1930; Capitani, 1966; Montclos, 1971; Silvestre, 1973; Cantin, 1974; Behrends, 1975; Capitani, 1975; Chadwick, 1990; Gibson, 1990; MaCy, 1990; Radding, 1992; Cristiani, 1993; BrouWer, 1996; Holopainen, 1998; Gamberini, 2005.

54. D'ONOFRIO, 1996, p. 452-453, 477-479.

55. Gibson, 1978; Lanfranco di Pavia e l'Europa, G. D'Onofrio (ed.), 1993; Cowdrey, 2003.

56. Cottineau, 1935-1937, vol. I, col. 316-319.

57. Ibid., col. 550-553.

58. WATKIns, 2006.

59. For a complete handlist of Lanfranc's works, including the spurious ones, cf. Gibson, 1978, p. 239-248, which limits his production in prose to Commentarius in omnes Pauli epistolas, Consuetudines, De corpore et sanguine Domini, Decreta, Epistolae.

60. The poem, inc.: "Ebdomada prima Martis ieiunia prima" (WALTHER, 1959, no. 5057): 14 leonine hexameters, is edited by Gibson, 1978, p. 241. 
poet moved north: William of Apulia ${ }^{61}$, despite this name, seems more probable to have been a Norman gentleman who travelled and wrote his renowned epos, Gesta Roberti Wiscardi ${ }^{62}$, in Southern Italy, sometime between 1095 and 1099.

Around the same period, in Le Bec, the Caen native Roger ${ }^{63}$ composed De professione monachorum ${ }^{64}$, which is found in many manuscripts ${ }^{65}$. It is a sharp censure of monastic vices, together with an exhortation to the corresponding virtues, in the frame of an authentic contemptus et fuga mundi. It is not clear if the subject of the verse is the Beccensis abbey or, considering the origin of the author, the monastery of Saint-Étienne.

The latter is indeed the main polemic target of Serlo of Bayeux ${ }^{66}$. His father was a priest, who left him, together with the parish nearby Caen, some landholdings, which are the subject of a poem against an unknown knight ${ }^{67}$ as well as, some

61. RoncA, 1892, vol. I, p. 372-373; Rossi, 1904, p. 201-243; GHELlinCK, 1939, vol. II, p. 100-101; Fuiano, 1950-1951; Fuiano, 1960; Roscini, 1967; Hoffmann, 1969, p. 115-119; Wolf, 1995, p. 123-141; Albu, 2001, p. 110; D’Angelo, 2003a, p. 13-14; D'ANGELO, 2003b, p. 28-29; ANGELINI, 2014.

62. Gesta Roberti Wiscardi is a long poem, written in hexameters: a 13-lines prologue, inc.: "Gesta ducum veterum veteres cecinere poetae" (WALTHER, 1959, no. 7197), and 2189 verses of the text, inc.: "Postquam complacuit regi mutare potenti", which has been transmitted only by the manuscript Avranches, Bibl. patrimoniale 162 [saec. XII ex., from Mont Saint-Michel abbey]. The text is available in Guillaume de Pouille, La Geste de Robert Guiscard, M. Mathieu (ed.) [with French translation], and in Guglielmo il Pugliese, Le gesta di Roberto il Guiscardo, R. Leotta (ed.) [Italian translation]. On this work: Guillelmi Apuliensis Rerum in Italia ac Regno Neapolitano Normanicarum libri quinque, J. Tiremaeus (ed.) [editio princeps, based upon a lost manuscript from Le Bec abbey]; Guillielmi Apuliensis Rerum in Apulia, Campania, Calabria et Sicilia Normanicarum libri quinque, I.B. CARusius (ed.); Guilielmi Appuli Historicum poema de rebus Normannorum in Sicilia, Appulia, et Calabria gestis, L. A. Muratori (ed.); Guillermi Apuliensis Gesta Roberti Wiscardi, R. Wilmans (ed.), p. 241-298; Hirsch, 1864, p. 28-37; Bottini Massa, 1889; Ronca, 1892, vol. I, p. 403-409, vol. II, p. 32-34; Catalano Tirrito, 1903, p. 97-98; Chalandon, 1907, vol. I, p. xxxviii-xl; Pagano, 1909; Fuiano, 1950; Mathied, 1950; Mathied, 1954; Leotta, 1976; Oldoni, 1977, p. 162-166; De Marco, 1983, p. 381-382; Oldoni, 1985, p. 367; Tilliette, 1985, p. 125-142; Bertini, 1988, p. 89; Schaller, 1993, p. 30; Tateo, 1995, p. 153-165; Tramontana, 1997, p. 22-23, 35-36; Albu, 2001, p. 111-144; D'ANgelo, 2003a, p. 30-32, 76-77; D'Angelo, 2003b, p. 29-30; LAuletta, 2003; Toubert, 2006; BisANTI, 2008; STELla, 2012; D'ANGELO, 2014.

63. Hauréau, 189o, p. 78-80; Bultot, 1964, p. 50-72.

64. De professione monachorum [sive: De contemptu mundi; De vita monachorum; De monachis], inc.: "Quid deceat monachum vel qualis debeat esse" (WALther, 1959, no. 15778), 406 elegiac couplets, ed. under the names of other authors: SANCTI ANSELMI ex Beccensi abbate Cantuariensis archiepiscopi Opera, G. Gerberon, (ed.) [reimpr. in PL, vol. CLVIII, 1853, col. 687-706: text attributed to Anselm of Canterbury]; The Anglo-Latin Satirical Poets and Epigrammatists of the Twelfth Century, Th. Wright (ed.), p. 175-200 [the work is assigned to Alexander Neckham]. Cf. Tractatus de professionibus monachorum (from Le Bec, 1136), in Three Treatises from Bec on the Nature of Monastic Life, G. Constable (ed.), B.S. Smith (trad.), p. 31-105.

65. Cf. SHARPE, 2001, p. 584.

66. Böhmer, 1897; Raby, 1934, vol. II, p. 45-48; Serlon de Wilton, Poèmes latins, J. Öberg (ed.), p. 1-2; van Houts, 1989, p. 44-45; RIGG, 1992, p. 66; SharPe, 2001, p. 603-604; van Houts, 2013; D'Angelo, 2014; van Houts, 2016; LuCAS-Avenel and D'Angelo, 2017.

67. Invectio in militem, qui causa paupertatis seculum relinquens in monacatu divitias adeptus est, inc.: "Quondam miles erat, sine re (regno) qui nomen habebat" (WALTHER, 1959, no. 16348): 58 leonine hexameters, ed. in Boutémy, 1938 [in particular, for the edition, p. 254-260 and 255-257]. 
years later (between 1079 and 1080), against the monks ${ }^{68}$ and, on two different occasions, the abbot of Saint-Étienne de Caen ${ }^{69}$. Odo, Bishop of Bayeux ${ }^{70}$, came to Serlo's aid and even appointed him as a cathedral canon. Subsequently, in 1087, the poet addressed to him a famous encomiastic poem to celebrate his release from imprisonment by his half-brother, William the Conqueror ${ }^{71}$. The same tone recurs in celebrating the nun Muriel ${ }^{72}$ in a long composition ${ }^{73}$. In fact, the lyre of the Norman author was not a monochord; it had instead many strings, as the remainder of his output confirms: the (auto-)apology on the priests' sons ${ }^{74}$, which was probably composed after 1095; the satire against sodomites ${ }^{75}$; the complaint about the 1105 conquest of Bayeux ${ }^{76}$ by King Henry $I^{77}$. The initial hostility against the sovereign and his wife Matilda ${ }^{78}$ must have been soothed later, if a short elegy for the Queen ${ }^{79}$ is authentic; there are some other pieces whose attribution is doubtful ${ }^{80}$.

68. Invectio in monachos, inc.: "Que monachi querunt, patrio mea iure fuerunt" (WALTHER, 1959, no. 15005): 186 leonine hexameters, ed. in The Anglo-Latin Satirical Poets..., Th. WRIGHT (ed.), p. 202-207 [182 verses]; BouTÉMY, 1938, p. 260-269 [ecdotical remarks, based on a larger recensio codicum].

69. These are both poems in leonine verse: Invectio in Gillebertum abbatem Sancti Stephani Cadomensis, inc.: "Secretis mensis ieiunus gaudente lunensis" (WALTHER, 1959, no. 17444): 94 hexameters, ed. in The Anglo-Latin Satirical Poets..., Th. WRIGHT (ed.), p. 251-254; the poem, inc.: "Questus quos fundo veniunt de corde profundo": 58 elegiac distichs, ed. by BoutÉmY, 1938, p. 244-247.

70. BATES, 1975; BATES, 1997; BATES, 2004a.

71. Ad Odonem Baiocensem episcopum versus, inc.: "Sidereos cives nunc et per saecula dives" (Walther, 1959, no. 18175): 15 leonine distichs, ed. in The Anglo-Latin Satirical Poets..., Th. Wright (ed.), p. 254.

72. Tatlock, 1933a; Tatlock, 1933b; Dronke, 1984, p. 85; Signori, 1995; Stevenson, 2005, p. 95-100.

73. Versus ad Muriel sanctimonialem, inc.: "Dum nostrum poscis carmen, quod inutile noscis" (WAlther, 1959, no. 4912): 281 leonine hexameters, ed. in The Anglo-Latin Satirical Poets..., Wright (ed.), p. 233-240; cf. also Boutémy, 1935, p. 242-243.

74. Versus de filiis presbyterorum, inc.: "Rex immortalis quam longo tempore talis" (WALTHER, 1959, no. 16733): 143 leonine hexameters, ed. in The Anglo-Latin Satirical Poets..., Th. WRIGHT (ed.), p. 208-212, and Serlo of BAyeux, Defensio pro filiis presbyterorum, E. DüMMLER and H. BöHMER (eds), p. 579-583.

75. In sodomitas, inc.: "Nos uxorati sumus ad ludibria nati": 44 leonine hexameters, ed. in LENZEN, 1990 [in particular, for the edition, p. 189-190].

76. Versus de capta Baiocensium civitate, inc.: "Corde fero tristi, quod tam cito capta fuisti" (WALTHER, 1959, no. 3316): 239 leonine hexameters, ed. in The Anglo-Latin Satirical Poets..., Th. Wright (ed.), p. 241-251, and SERLo of BAYeux, Defensio pro filiis presbyterorum, DüMmLER and BöHMER (eds), p. 717; Serlo of Bayeux, De capta Baiocensium civitate, M. Arbabzadah (ed.), in van Houts, 2013, Appendix 3, p. 86-91; Arbabzadah, 2017.

77. Southern, 1962; Brett, 1975; Green, 1986; Green, 2003; Hollister, 2004; Green, 2006.

78. Strickland, 1850, p. 79-118; HUNEYCUTT, 2003; HUNEYCUTt, 2004 b.

79. The poem, inc. "Septem maiores numeramos in aethere stellas" (WALTHER, 1959, no. 17532): 14 elegiac couplets, ed. in BoutÉmy, 1937 [in particular, for the edition, p. 304-305]; cf. van Houts, 1989 , p. 51.

80. Versus de contemptu mundi, inc.: "Quisquis amicitiam non vult vitare notandam" (WALTHER, 1959, no. 16152): 36 mostly leonine hexameters and elegiac couplets, ed. in The Anglo-Latin Satirical Poets..., Th. Wright (ed.), p. 232-233; Ad virginem Deo dicatam versus, inc.: "Pro corruttibili plenoque dolore cubili" (WALTHER, 1959, no. 14745): 34 leonine hexameters, ed. in The Anglo-Latin Satirical Poets..., Wright (ed.), p. 240-241; Versus, inc.: "Rus habet in silva 
This literary example shows that in this period the main direction of poetry was north. In this respect, it is worth noting the poetry that goes under the label of rotuli funebres $^{81}$ : the rolls circulating among ecclesiastical institutions to commemorate specific religious personalities by prayers, often in verse, by famous authors or otherwise unknown French, Norman and English versifiers. These literary creations and their respective contents crossed the Channel and gathered a great deal of praise and complaint, as happened on the occasion of the death of Bruno of Cologne $^{82}$, Vitalis of Savigny ${ }^{83}$ and Matilda, abbess of Sainte-Trinité of Caen ${ }^{84}$.

Throughout this period, which dates back to the Norman Conquest, the transfer to England was constantly increasing, not only from Normandy, but from Flanders too. In fact in the mid-eleventh century many monks from Saint-Omer ${ }^{85}$ entered the English royal court: Hermann, Bishop of Ramsbury ${ }^{86}$, protector of Goscelin of St Bertin ${ }^{87}$, who wrote, in Canterbury, many hagiographies in prose ${ }^{88}$ and, at least in one case, the Vita sanctae Edithae ${ }^{89}$, also comprising 14 parts in

patruus meus: huc mihi sepe" (WALTHer, 1959, no. 16947): 79 hexameters, ed. in The Anglo-Latin Satirical Poets..., Th. Wright (ed.), p. 255-257; Ad amicum absentem, inc.: "Si quid in urbe colis, quod ames, quod perdere nolis" (WALTHER, 1959, no. 17899): 12 leonine hexameters, ed. in The Anglo-Latin Satirical Poets..., Th. WRIGHT (ed.), p. 257; Invectio in mordacem cinaedum, inc.: "Audi, fex iuvenum, cuius sunt verba veneno" (WALTHER, 1959, no. 1696): 23 leonine hexameters, ed. in The Anglo-Latin Satirical Poets..., Th. Wright (ed.), p. 257-258.

81. Rouleaux des morts du IX au XV siècle, L. Delisle (ed.); Dufour, 2003; for a wide collection of texts (scores of epigrams in hexameters or distichs), cf. Recueil des rouleaux des morts (VIII ${ }^{e}$ sièclevers 1536), J. Dufour (ed.). See furthermore PARISSE, 2007, Goullet, 2016.

82. Rüther, 1936; Landgraf, 1940; Ravier, 1967; San Bruno e la Certosa di Calabria, P. De Leo (ed.), 1995; Saint Bruno en Chartreuse, A.R. Girard et al. (ed.), 2004; San Bruno di Colonia: un eremita tra Oriente e Occidente, P. De Leo (ed.), 2004; Vermigli, 2007; Peters-Custot, 2014.

83. VAN Houts, 1989, p. 45; MoOlenbroek, 1990.

84. Van Houts, 1989, p. 45; Goullet, 2010

85. CotTINEAU, 1935-1937, vol. II, col. 2829.

86. Grierson, 1941, p. 101, n. 4; Barrow, 2004.

87. Hamilton, 1973; Gosling, 1990; LAPIDGE and Love, 2001, p. 225-233; HAYWARD and Barnes, 2004; Hollis, 2004; van Houts, 2006a; van Houts, 2006b; Beare, 2008; Keynes and Love, 2009, p. 204-207; KoOpMANS, 2011, p. 60-67; LiCENCE, 2011, p. 6o-63; Love, 2013.

88. Works about Amalberga (in BHL, no. 323); Augustinus (ibid., nrr. 777-781; a Sermo is transmitted by ms London, British Library, Cotton Vepasian B XX, ff. 86r-93v); Deusdedit (in BHL, no. 2153); Edmundus (ibid., no. 2398b); Edwoldus (ibid., no. 2429: dubious); Eorcengota (Vita transmitted by mss Cambridge, Corpus Christi College 393 [I. 13], ff. 81v-82v and Cambridge, Trinity College O.2.1 [1105], f. 236); Eormmelhilda (in BHL, no. 2611); Ethelburga, Hildelitha, Wulfhilda (ibid., nrr. 263ob, 263od, 2630e, 2631b, 3942, 8736d); Hadrianus (ibid., nrr. 3740, 3742); Honorius archiepiscopus (Vita transmitted by mss London, British Library, Cotton Vespasian B XX, ff. 217r-22or and London, British Library, Harley 105, ff. 246v-249r); Iustus (in BHL, no. 4601); Ivo (ibid., nrr. 4621-4623); Kenelmus (ibid., nrr. 4641n-4641t); Laurentius (ibid., no. 4741); Letardus (ibid., no. 4892); Mellitus (ibid., no. 5896); Milburga (Vita transmitted by mss Gotha, Forschungs- und Landesbibliothek [olim Forschungsbibliothek], Mbr. I. 81, ff. 166v-175r; Lincoln, Cathedral Library 149 [B.1.9], ff. 83v-87r; London, British Library, Add. 34633, ff. 206r-216r; London, Lambeth Palace Library 94, f. 169); Mildretha (in BHL, nrr. 5960-5962, 5964; an Officium is transmitted by ms London, British Library, Harley 3908, ff. 35-50); Sexburga (in BHL, no. 7693); Theodorus (ibid., no. 8083); Werburga (ibid., nrr. 8855-8856); Withburga (ibid., no. 8979); Wulsinus (ibid., no. 8753)

89. Vita sanctae Edithae (ibid., no. 2388), ed. in WILMART, 1938; on this work cf. The life of King Edward..., F. BARLOW (ed.), p. 135-138; RidyARD, 1988, p. 140-148; HAYWARD, 1999, p. 77-79; 
various rhythmic metres; Folcard ${ }^{90}$ belonged to the same Flemish abbey, before going to England, first (sometime between 1066 and 1069) to Thorney abbey ${ }^{91}$ and later, after 1085 , to the Primate Lanfranc. It is very regrettable that such an important author of Norman saints' lives ${ }^{92}$ had left, in terms of poetry (beside the mere notice of some deperditi versus) only an uncertain Carmen de sancto Vigore $^{93}$.

All of these texts, together with an anonymous prosimetrum on Edward the Confessor's life ${ }^{94}$, deal with the patron saints of the bold enterprise of William the Conqueror. He is also the focus, often praised as a novus Caesar ${ }^{95}$, of a group of short epigrams: they are mostly anonymous ${ }^{96}$, but there are definitely some French poets too, as in the cases of Hugh-Renard of Langres ${ }^{97}$ or Guy, Bishop of Amiens ${ }^{98}$, the author of the famous Carmen de Hastingae proelio ${ }^{99}$.

After William's death, his figure was still central to some epitaphs. The majority of them belongs to unknown authors ${ }^{100}$, but there are some exceptions,

YORKe, 2003; Wright and LONCAR, 2004; O'Brien O'KeEFFe, 2005; Hollis, 2006; KARKov, 2008; Emons-NiJenhuis, 2009; LeYSeR, 2011, p. 50-51; O’Brien O'KeEFFe, 2012, p. 151-156, 158-168, 178-184

90. LAPIDGE, 1983; LAPIDGE, 1992, p. 180-181; LAPIDGE and Love, 2001, p. 235-237; Ugé, 2005, p. 170171; VAN HouTs, 2006b, p. 115-116, 120-123; ANGELINI, 2010.

91. Cottineau, 1935-1937, vol. II, col. 3151.

92. He wrote the Lives of Bertinus abbas (in BHL, no. 1293); Botolphus (ibid., nrr. 1428-1431); Eduardus Anglorum rex, dictus Confessor (ibid., no. 2421); Iohannes Beverlacensis (ibid., no. 4339). On the hagiographical works about Tancredus, Torhtredus, Tova and other saints of Thorney, beside a lost Vita Oswaldi Wigorniensis, cf. LAPIDGE and Love, 2001, p. 236.

93. Carmen de sancto Vigore (in BHL, no. 8614), ed. in Spicilegium sive collectio veterum aliquot scriptorum qui in Galliae bibliothecis delituerant, L. d'ACHERY (ed.), p. 576-577; on this text, cf. BAudot and Chaussin, 1950, p. 50-56.

94. The text of Vita Aedwardi regis, already published in Lives of Edward the Confessor I, H.R. LuARD (ed.), p. 390-435, is also available in The life of King Edward..., F. BARLOw (ed.), p. 2-127; cf. also SOUTHERn, 1943b; RIGG, 1992, p. 12-14; GrANSDEN, 1997, p. 64-66; Grassi, 2004. 95. VAN Houts, 1989 , p. 41-44.

96. They are respectively: 3 hexameters, inc.: "Anno milleno sexageno quoque seno"; a distich, inc.: "Caesariem, Caesar, si tibi Natura negavit" (WALTHER, 1959, no. 2297); the single leonine verse "Nec pice, nec clavis eget haec argentea navis". All of the short poems are ed. and studied by van HouTs, 1989, p. 41 and 43.

97. Hugh is the author of only a distich, inc.: "Si quis ante videt qui te circumspicit ex te", ed. by VAN Houts, 1989 , p. 42

98. LAPIDGE, 2014a.

99. Carmen de Hastingae Proelio, inc.: "Quem probitas celebrat, sapientia munit et ornat" (WALTHER, 1959, no. 15366): 417 elegiac couplets, ed. in Chroniques anglo-normandes, F. MicheL (ed.), p. 1-38; Guy of Amiens, The "Carmen de Hastingae proelio" of Guy Bishop of Amiens, C. Morton and H. Muntz (eds) [about this edition cf. the review by OrLAndi, 1972]; Guy of Amiens, The "Carmen de Hastingae proelio" of Guy Bishop of Amiens, F. BARLow (ed.). On this text cf. Barlow, 1967; Engels, 1967; Davis Ralph H.C., 1978; Davis and Engels, 1979; Hall, 1980, p. 903-907; Hirsh, 1982; OWen, 1982; Hermans and van Houts, 1983; Sayers, 1983; van Houts, 1989, p. 53-56; OrLANDi, 1996; D'ANGelo, 2014.

100. In the group of four anonymous epitaphs, two of them are in couplets of rhythmical and rhymed lines, respectively a poem, inc.: "Bellatorum fortissimus, Anglorum invictissimus" (WaLther, 1959, no. 2122): 20 verses 8pp repeated, ed. in Chroniques des Eglises d'Anjou, P. Marchegay and E. MABille (ed.), p. 139; a second one, inc.: "Flete, viri, lugete, proceres" (WALther, 1959, no. 6623): 48 lines 1opp, ed. in Scriptores rerum gestarum Willelmi Conquestoris, J.A. GiLes (ed.), 
which come once more from France. One exception, and the first name of great renown, is Geoffrey of Cambrai ${ }^{101}$, who was active from 1070 onwards and, about ten years laters became prior at Saint Swithun in Winchester until his death in $1107^{102}$. He was, at the time, one of the main poets in the English area with his collection called Liber proverbiorum ${ }^{103}$, which gathers short pieces dealing with satirical topics: they are often exhortations to wisdom and temperance, in the style of Martial, with frequent recourse to fictional stock characters (like Damianus, Coranus and Didimus). His Epigrammata historica ${ }^{104}$ contain encomiastic or obituary verses about high-ranking figures, such as Anglo-Norman kings and queens or their relatives and friends, often bishops or abbots. In this poetic group Matilda of Flanders deserves a place of particular honour for the mournful lines dedicated to her ${ }^{105}$. Once again William I occupies an important position, because of the short elegy that celebrates his passing ${ }^{106}$.

Thomas, sometime Canon of Bayeux and (1070-1100) Archbishop of York ${ }^{107}$, is the author of a similar epitaph ${ }^{108}$, which gives us the opportunity to examine the environment around his diocesan chair. The first of his two successors, who were both Norman, was Gerhard (died in 1108 ) ${ }^{109}$, a relative of the first Anglo-Norman kings and important dignitaries; he himself soon gained a high position both in the church and at court, even before crossing the Channel. He

p. 73-74; the remaining two texts are in distichs, 18 verses in the whole, inc.: "Clauderis his modico pie Rex Willelme sepulcro", ed. in Guilielmi Neubrigensis Historia, Th. Hearne (ed.), p. 685-686, or in part of the 5 hexameters and 7 elegiac couplets, inc.: "O mors! Cui parces cum regna destruis arces?", ibid., p. 686-687. Cf. van Houts, 1989, p. 43.

101. MAAZ, 1983, p. 101-113; RIGG, 1992, p. 17-20, 64-6; SCHRÖDER, 1999, p. 222-223; RIGG, 2004b; VALlat, 2008, p. 966-970; LAPIDGE, 2012.

102. CotTineau, 1935-1937, vol., II, col. 3457-3458.

103. Liber proverbiorum (sive Epigrammata): 238 poems, each of them counts from one to nine elegiac couplets, ed. in The Anglo-Latin Satirical Poets..., Th. Wright (ed.), p. 103-147; Gerhard, 1974.

104. Epigrammata historica: Versus de primatum Angliae laudibus, texts in hexameters or distichs from 5 up to 28 verses, ed. in The Anglo-Latin Satirical Poets..., Th. Wright (ed.), p. 148-155 [19 poems] and LAPIDGE, 1987, p. 69: edition of the two Epigrammata additicia, respectively inc.: "Vas virtutis et in vitium non flexile robur" and "Vir magni meriti, vir magne strenuitatis"; cf. van HouTs, 1989, p. 46 on the epitaph for Richard, second son of the Conqueror, De Richardo regis Willelmi filio, inc.: "Magnanimo spes laudis eras, Richarde, parenti" (WALTHER, 1959, no. 10575): 5 distichs, ed. in The Anglo-Latin Satirical Poets..., Th. WRIGHT (ed.), p. 152; MAAz, 2001.

105. The epitaph De Mathilda regina, inc.: "Consilii virtus decor oris, gratia verbi" (WALTHER, 1959, no. 3185): 6 distichs, ed. in The Anglo-Latin Satirical Poets..., Th. Wright (ed.), p. 150; cf. van Houts, 1989, p. 46.

106. De rege Gilielmo, inc.: "Regnum, forma, genus, cor, dextra, facetia, virtus" (WALther, 1959, no. 16544): 6 elegiac couplets, ed. in The Anglo-Latin Satirical Poets..., Th. Wright (ed.), p. 149150; cf. van Houts, 1989, p. 43.

107. Hardy, 1865, p. 91; Barlow, 1979, p. 33, 250, 283-284; Barlow, 1983, p. 95, 198-199; Chibnall, 1986, p. 39-40, 126-127, 152; RIGG, 1992, p. 10, 35, 52; COWDREY, 1998; NoRTON, 2001; COWDREY, 2004 .

108. Versus, inc.: "Qui rexit rigidos Normannos atque Britannos" (WALTHER, 1959, no. 15639): 4 elegiac couplets, in The Ecclesiastical History of Orderic Vitalis, M. CHIBNALL (ed.), book VIII, vol. IV, p. 110-112; cf. BARLOW, 1983, p. 51; van Houts, 1989, p. 43.

109. Galbraith, 1931; Williams, George, 1951, p. 88-90; Fröhlich, 1970, p. 118-125; Barlow, 1979, p. 72, 77, 79-81; BURTON, 2004a; LAPIDGE, 2013. 
was the author of a Carmen de David psalmista ${ }^{110}$ in elegiac couplets, the same metre that Thomas II ${ }^{111}$, nephew of Thomas of Bayeux, used for an epistle ${ }^{112}$ to express concord between Canterbury and his own metropolitan see ${ }^{113}$. After 1114, under the vigorous Yorkist Thurstan ${ }^{114}$, who held the archdiocese until 1140, Hugh Cantor Sotovagina ${ }^{115}$, probably a cathedral archdeacon died ca. 1139, wrote his famous works: the Historia ecclesiae Eboracensis ${ }^{116}$, which gathers documents to show that there was no Cantuariensis primacy; the Carmen de proelio Standardii ${ }^{117}$; a satirical elegy, which puts together proverbial and moral lore in the manner of Disticha Catonis ${ }^{118}$.

As for the Canterbury side, after the arrival of Lanfranc, Gilbert Crispin ${ }^{119}$ (a Norman nobleman, between 1070 and 1078 a monk at Le Bec) was a leading figure in the religious and intellectual migration from the continent to England. There he became chaplain of the Italian Archbishop, in contact with his foremost disciples, even after 1085, when he gained and held, until his death in December 1117, rule over Westminster Abbey ${ }^{120}$. At least four poems survive of his own: three of them are reflections about Genesis ${ }^{121}$ or sacraments (De confessione ${ }^{122}$; De corpore et sanguine Domini ${ }^{123}$ ). But the last one ${ }^{124}$ is the most relevant, partly for the adonic metre, but mainly for the recipient: Anselm, the Primate of Canterbury ${ }^{125}$, a theologian from Northern Italy like Lanfranc,

110. Carmen de David psalmista, inc.: "Rex citharista David": 6o lines, ed. in Mozley, 1942, p. 8.

111. Barlow, 1979, p. 43, 82; BURTON, 2004c.

112. Disticha Raginaldo, inc.: "Affectum mentis, demonstrant (designant) verba loquentis" (WALTHER, 1959, no. 668): 7 leonine distichs, ed. in Liebermann, 1888, p. 548-549, no. XIX.

113. On the contrast between the two archdiocesan sees, cf. BARLOw, 1979, p. 39-44.

114. NiCHOLL, 1964; BURTON, 2004d.

115. Clay, 1941; Clay, 1946; Rigg, 1992, p. 52; Burton, 2004b.

116. Historia ecclesiae Eboracensis (sive Historia quattuor archiepiscoporum Eboracensium), ed. by RAINE, 1886, p. 98-227; furthermore, ed. with translation and commentary in HuGH THE Chanter, The History of the Church of York: 1066-1127, Ch. Johnson (ed.). On the historical text cf. Southern, 1958; TAYLOR, 1961, p. 13; GrANSDEN, 1997, p. 123-125.

117. There is only a surviving distich, inc.: "Dicitur a stando Standardum, quod stetit illic", ed. in The Historians of the Church of York and Its Archbishops, J. RaIne (ed.), p. 90.

118. Versus, inc.: "Philosophus quidam quesitus, quid sit amicus" (WALther, 1959, no. 14077): 362 elegiac verses, ed. in The Anglo-Latin Satirical Poets..., Th. Wright (ed.), p. 219-229.

119. Robinson, 1911; Southern, 1943a, p. 14, 19-22; Southern, 1954; LeClerCQ, 1959; Luff, 1961; Evans, 1980a; Evans, 198ob; Evans, 1981, p. 31; Chiti, 2013.

120. Cottineau, 1935-1937, vol. II, col. 3447-3449.

121. De creatione sex dierum, inc.: “Unde dies, inquam, primus quo condita fit lux?": 28 hexameters, ed. in The Works of Gilbert Crispin Abbot of Westminster, A.S. Abulafia and G.R. Evans (eds), p. 177.

122. De confessione, inc.: "Crimina deploret sua sic pecator et oret" (WALTHER, 1959, no. 3451): 32 leonine hexameters or rhymed in pairs, ed. in The Works of Gilbert Crispin..., A.S. ABulafiA and G.R. Evans (eds), p. 180-181.

123. De corpore et sanguine Domini, inc.: "Mysterio magno legali vescimur agno" (WALther, 1959, no. 11545): two redactions of respectively 42 and 48 rhymed hexameters, ed. in The Works of Gilbert Crispin..., A.S. Abulafia and G.R. Evans (eds), p. 178-180.

124. Ad Anselmum archiepiscopum, inc.: "Que modulando": 78 adonics, ibid., p. 182.

125. Stolz, 1937; Southern, 1943a; VAnni Rovighi, 1987; Southern, 1990; Corbin, 1992; Biffi, 1996; LOVE, 2001. 
his predecessor and teacher. Although his surviving writings do not include any poetry, he was undoubtedly of importance to contemporary literature. He was also the subject of another two anonymous poems (once mistakenly attributed to William of Chester ${ }^{126}$ ): a Carmen in laudem ${ }^{127}$ and an Epicedion in obitum ${ }^{128}$. The most reliable biographical work is Vita sancti Anselmi $i^{129}$, by the very prolific hagiographer Eadmer of Canterbury ${ }^{130}$, who was also the author of the poem Hymnus in honore sancti Dunstani ${ }^{131}$ about an important Saxon saint, one of the most celebrated patrons of the metropolitan chair.

Doubtfully attributed to Herman the archdeacon (b. 1040/1050-d. ca. 1100) ) $^{132}$ is the poem On the Heresy Simony ${ }^{133}$ about Herbert Losinga ${ }^{134}$, a nobleman who was born and educated in Normandy, before gaining the rule of Ramsey Abbey ${ }^{135}$ and then, about the year 1090, the bishopric of Thetford-Norwich, suffragan of the Primate see. In this ecclesiastical centre, but at the abbey of St Augustine ${ }^{136}$, Reginald ${ }^{137}$, a Frenchman born between 1040 and 1050 (and died in 1109 or 1112) in Faye-la-Vineuse in Poitou, after having received his education in Tours, was

126. SHARPE, 1985

127. Carmen in laudem sancti Anselmi Archiepiscopi Cantuariensis, inc.: "Haud habiture parem sumas, pater alme” (WALTHER, 1959, no. 7673): 57 elegiac couplets, ed. in STEPHANi BALUzII miscellaneorum liber primus..., vol. IV, 1683, p. 557-56o [reimpr. in PL, vol. CLVIII, 1853, col. 135-138]; SHARPE, 1985, p. 271-274.

128. Epicedion in obitum sancti Anselmi Archiepiscopi Cantuariensis, inc.: "Presulis Anselmi librum fore non dubitetis" (WALTHER, 1959, no. 14486): 110 elegiac couplets, ed. in STEPHANI BALUZII miscellaneorum liber primus..., vol. IV, 1683, p. 560-566 [reimpr. in PL, vol. CLVIII, 1853, col. 137-142]; SHARPE, 1985, p. 274-279.

129. Vita sancti Anselmi (in BHL, no. 525-526), ed. in PL, vol. CLVIII, 1853, col. 49-117; The life of Saint Anselm, Archbishop of Canterbury, by Eadmer, R.W. Southern (ed.), p. 1-15.

130. KNOWLES, 1949, p. 109 [et ad indicem]; SOUTHERN, 1963, p. 229-240, 274-354, 367-374; SOUTHERN, 1990, p. 404-421; WebBer, 1995, p. 148-149; GULlick, 1998; EAdMER OF CANTERBURY, Lives and miracles of saints Oda, Dunstan, and Oswald, Andrew, J. Turner and B.J. Muir (eds), p. xiii-xxxv; LAPIDGE, 2009a.

131. Hymnus in honore sancti Dunstani: 20 elegiac couplets, ed. in Memorials of Saint Dunstan, Archbishop of Canterbury, W. STuBBs (ed.), p. 424-425.

132. On this figure, cf. Herman the Archdeacon and Goscelin of Saint-Bertin, Miracles of St Edmund, T. LICENCE (ed.), p. xxxv-liv.

133. De symoniaca haeresi (or De simonia et nummo) is transmitted in three different forms: a recensio longior, inc.: "Crevit in ecclesia monstrum genitore Losinga" (WALTHER, 1959, no. 3440): 50 hexameters, De simoniaca haeresi carmen, ed. in Serlo of BAyeux, Defensio pro filiis presbyterorum, DüMmLER and BöHMER (eds), p. 615-617, but also in Herman THE ARCHDEACON and Goscelin of Saint-Bertin, Miracles of St Edmund, T. Licence (ed.), p. xcvi-cvi, 352-354 [Appendix II On the Heresy Simony]; recensio brevior I, inc.: "Surgit in ecclesia monstrum genitore Losinga" (WALTher, 1959, no. 18920): 22 lines, in London, British Library, Royal 8.E.XVIII, f. 77v, ed. in Willelmi Malmesbiriensis monachi De Gestis Regum Anglorum Libri Quinque, W. Stubis (ed.), vol. II, p. 386; recensio brevior II, inc.: "Petre nimis tardas" (Walther, 1959, no. 14029) which misses the first two lines of the previous one, in Oxford, Bodleian Library, Auct. F.2.14 (S.C. 2657)

134. Goulburn and Symonds, 1878; Alexander, 1969; Batcock, 1988, p. 188; Harper-Bill, 2004; Herman the Archdeacon and Goscelin of Saint-Bertin, Miracles of St Edmund, T. LiCENCE (ed.), p. xcvi-cix.

135. Cottineau, 1935-1937, vol. II, col. 2401.

136. Ibid., vol. I, col. 587-588.

137. RIGG, 1992, p. 24-30; RIGG, 2004a. 
the author of 36 pieces $^{138}$ in scores of hexameters or distichs: mostly leonini, caudati or trinini salientes (one of them is entirely in pentameters ${ }^{139}$ ) about eminent contemporary political or ecclesiastical personalities and even about his birthplace. The majority has a satirical tone or a connection with specific literary or political circumstances (such as the Anselmian exiles); about twelve poems concern Canterbury saints: Augustine, Lawrence, Mellitus, Justus, Honorius, Deusdedit, Theodore, Hadrian, Mildred, Letard, Ethelbert and Bertha. A relevant lyric exception is a poem in Sapphics ${ }^{140}$ for Osbern of Canterbury ${ }^{141}$. His masterpiece is the famous Vita sancti Malchi ${ }^{142}$, which he wrote in 1104-1107, on behalf of Abbot Gilbert Crispin. This metrical hagiography is important for the use of the versification displayed in the Loire Valley as a model of reference, as recognised by the poet himself ${ }^{143}$.

During the entire age of the first Anglo-Norman kings, the renowned, and prolific, poets from Northern France, in particular the region crossed by the Loire ${ }^{144}$, were of great importance, starting with Fulcoius of Beauvais ${ }^{145}$, author of a comparison of William the Conqueror with the biblical Jephthah ${ }^{146}$; he also wrote two epitaphs for Queen Matilda of Flanders ${ }^{147}$.

Powerful women, more than their husbands or male relatives who held the most of power on either side of the Channel, were not only the main recipients but also subjects of praise in epistles ${ }^{148}$ and poems that were sometimes written for other well-known or important figures. This is the case for Geoffrey of Reims ${ }^{149}$ : he

138. Reginaldi monachi Poemata, ed. in The Anglo-Latin Satirical Poets..., Th. WRIGHT (ed.), p. 259-267 [5 poems]; in LiebermanN, 1888 [ 31 texts: the first 12 also published in Analecta Hymnica Medii Aevi, G.M. Dreves and C. Blume (eds), vol. L, p. 370-387, nrr. 287-298]; cf. also Szövérffy, 1965, p. 25-28; Killings, 2010.

139. Iohanne suo pape Raginaldus, inc.: "Impare cum numero gaudeat ipse Deus" (WALther, 1959, no. 8773): 30 pentameters, in LIEBERMANN, 1888, p. 548 , no. XVIII.

140. Exemplar Sapphici metri Osberno, inc.: "Discat Osbernus, studio frequenti" (WALther, 1959, no. 4522): 20 strophes long ed. in The Anglo-Latin Satirical Poets..., Th. Wright (ed.), p. 265-267, no. 5 .

141. Rubenstein, 1995, p. 27-40.

142. Vita sancti Malchi (in Bibliotheca Hagiographica Latina, no. 519ob): 6 books of 3344 leonine heroic lines in the whole, ed. Lind, 1942.

143. The most explicit witness is a letter addressed by Reginald to Hildebert of Le Mans, among the latter's, Epistolae III, 15, ed. in PL, vol. CLXXI, 1854, col. 292.

144. Cf. WAdDELL, 1927, p. 107-116; STEINEN, 1964; STEINEN, 1966; SzÖvÉrfFy, 1993, vol. II, p. 106-109; Pugh, 2000.

145. Olleris, 1842; LeComte, 1897; Boutémy, 1951; Colker, 1954, p. 191-198; Colker, 2002; Haye, 2002; ANGELINI, 2011

146. The poem, inc.: "Quae prius audieram, veni quod, mira viderem" (WALTHER, 1959, no. 15023): 50 hexameters, ed. in Colker, 1954, p. 245-246; cf. van Houts, 1989, p. 42.

147. Versus Mathildis Anglorum reginae, inc.: "Certe si fortis, si prudens, sobria, iusta” (WALTHER, 1959, no. 2651) and "Tempore quae nostro spectari posset in ostro" (WALTHER, 1959, no. 19139), respectively 29 hexametri and 14 leonini, ed. in OMONT, 1895, p. 223-225, nrr. 9-10; cf. van HouTs, 1989, p. 46.

148. Huneycutt, 1996; Ferrante, 1997, p. 98-103, 109, 111; Sesto Yagüe, 2012; Angelini, 2015; Tyler, 2017; Ferrante, 2018.

149. WattenbaCH, 1891, p. 101-113; Boutémy, 1945; Boutémy, 1947a; Boutémy, 1947b; Boutémy, 1949, p. 183-189; Williams, John, 1947; Williams, John, 1954, p. 670-672; Bezzola, 1960, vol. II/1, p. 22; SzÖvÉRfFy, vol. I, 1992, p. 375-384; JAEgER, 1994, p. 56-62, 114-115, 139-164; TillietTE, 
is the most probable author of a short encomium of William I as a novus Caesar ${ }^{150}$; there is no doubt about the authorship of the praises of the royal consort in the Epistola metrica ${ }^{151}$ to Archdeacon Ingelrannus of Soissons, who addressed a now lost poem ${ }^{152}$ on the sovereign to his daughter, Adela, Countess of Blois ${ }^{153}$.

In most cases a particular princess was at the same time the literary focus and dedicatee. Marbod of Rennes ${ }^{154}$, one of the most celebrated Loire authors, enjoyed widespread appreciation since the age of the sovereigns Henry and Matilda: in fact she was probably the recipient of his poem to the Queen of England ${ }^{155}$.

Baudri of Bourguei ${ }^{156}$ too was connected with the Anglo-Norman court, as witnessed by his obituary compositions: in addition to the epitaph for William I ${ }^{157}$ he wrote four metrical commemorations ${ }^{158}$ of his homonymous son and successor, who was also called Rufus ${ }^{159}$. The French poet also composed encomiastic lines

2002, p. 450-454; Carlos Villamarín, 2002b; Broecker, 2002; Broecker, 2003; Carlos Villamarín, 2003a; Carlos Villamarín, 2003b; Bon, 2005, p. 118; ANgelini, $2012 \mathrm{a}$.

150. About the poem De rege Willelmo, inc.: "Plus tibi fama dedit, quam posset musa Maronis" (WALther, 1959, no. 14209): 11 elegiac couplets, cf. VAn Houts, 1989, p. 41-42, on the question of authorship, and p. 56-57, for the critical edition.

151. Epistola metrica ad Ingelrannum archidiaconum de moribus eius, inc.: "Lux mores hodierna tuos Marcelle novavit" (SCHALler and KöNSGEN, 1977, no. 9127; WALTHER, 1959, no. 10512): 78 disticha, ed. in Wattenbach, 1891, p. 104-105, but there are more recent editions, such as Boutémy, 1947b, p. 340-344, and BroeCKer, 2002, p. 179-185; cf. Boutémy, 1938, p. 124; Boutémy, 1947a, p. 240-246; Williams, John, 1947, p. 32-33, 39-45; Dronke, 1965, p. 209-210; Latzke, 1979, p. 56-59; van Houts, 1989, p. 47-49; Carlos Villamarín, 2002a, p. 290-291; Carlos Villamarín, 2002b, p. 188.

152. On Ingelrannus and a lost poem by him on William the Conqueror cf. van Houts, 1989, p. 43 and 47-49.

153. Cf. Everett, 1849, p. 34-71; van Houts, 1989, p. 47-50; Lo Prete, 1990; Lo Prete, 1992a; Lo Prete, 1992b; Lo Prete, 1996; Huneycutt, 2004a; Lo Prete, 2007.

154. Ernault, 1889; Bezzola, 1960, vol. II/2, p. 384-424; Carmina Leodiensia, W. Bulst (ed.), p. 5-45; Devailly, 1980; Grégoire, 1977; Degl'Innocenti, 1990; Tilliette, 1992b, p. 982-983; MARbodo di Rennes, De ornamentis verborum - Liber decem capitulorum. Retorica, mitologia e moralità di un vescovo poeta (secc. XI-XII), R. LeOtTA and C. CRImi (eds); DALARUn, 2000.

155. Ad reginam Anglorum, inc.: "Est operae pretium tentasse pericula Ponti" (WALther, 1959, no. 5792): 15 elegiac couplets, ed. in PL, vol. CLXXI, 1854, col. 1660, no. XXIV, and in Balderico di Bourgueil, Marbodo di Rennes, Ildeberto di Lavardin, Lettere amorose e galanti, M. SANSON (ed.), p. 96-99, 136; cf. LATZKe, 1979, p. 54-56; van Houts, 1989, p. 50-51; Degl'InNOCEnTi, 1990, p. 8; Bisanti, 2010, p. 100.

156. Thurot, 1876; Pasquier, 1878; Schumann, 1931; Hilbert, 1967; Bond, 1986; Tilliette, 1992a; Tilliette, 1994; Mosetti Casaretto, 2003.

157. Super regem Anglorum, inc.: "Indice qui celo, qui presagante comete" (WALTHER, 1959, no. 9274): 3 distichs, ed. in Baudri de Bourgueil, Poèmes, J.-Y. Tilliette (ed.), p. 104, no. 174; cf. Les ceuvres poétiques de Baudri de Bourgueil (1046-1130), Ph. Abrahams (ed.), p. 74-75; van Houts, 1989, p. 43.

158. Each of the four poems, respectively inc.: "Nobilitas, regnum, prudentia, copia rerum" (WALTHER, 1959, no. 11886), "Qui regum magnus fuit admirabilis orbi" (ibid., no. 15632), "Qui legis hunc titulum, subtus cognosce sepultum" (ibid., no. 15518), "Sub cuius nutu tremuit Normannus et Anglus" (ibid., no. 18663), is 3 distichs long: ed. in Baudri de Bourgueil, Poèmes, J.-Y. Tilliette (ed.), p. 105-106, nrr. 175-178; cf. Les cuvres poétiques..., Ph. Aвrahams (ed.), p. 75-77; van Houts, 1989, p. 46.

159. Freeman, 1882; Grinnell-Milne, 1968; Mason, Emma, 1977; Hollister, 1973; Green, 1979; Callahan, 1981; Barlow, 1983; Mason, Emma, 1991; Barlow, 2004b; Mason, Emma, 2008. 
to a couple of Norman noblemen, Ricardus and Guillelmus, who were perhaps William's offspring ${ }^{160}$. Two of his daughters were addressees of well-known poems: two distinct pieces for Adela of Blois ${ }^{161}$ and an encomium of Cecily, abbess of Sainte-Trinite at Caen ${ }^{162}$. It is also worth noting that another learned nun, the above-mentioned Muriel of Wilton, was the recipient of a text in her honour ${ }^{163}$.

The latter three women were also subjects of particular interest in the works of Hildebert of Le Mans ${ }^{164}$. For Adela he wrote two short poems ${ }^{165}$ and at least four letters ${ }^{166}$, which often linger on the contrast between the female weakness and masculine virtue of the Countess, in the very same way as some anonymous lines addressed to her ${ }^{167}$. Each of the other two religious figures, Cecily and Muriel, is the addressee of a short elegy ${ }^{168}$. The same poetic form recurs more

160. Two texts ad Ricardum Normannum, inc.: "Si, Ricarde, meis precibus monitisque favebis", and ad Guillelmum Normannum, inc.: "Intonsi crines capitis, dissuta lucerna" (WALther, 1959, no. 9500): respectively 12 hexameters and 9 distichs, ed. in BAUdri DE Bourgueil, Poèmes, J.-Y. Tilliette (ed.), p. 57-58, nrr. 149-15o. Razzoli, 1936, p. 37-38, argues that the two noblemen were sons of King William the Conqueror; against this hypothesis cf. BAUdRI DE BourgueIL, Poèmes, J.-Y. TillietTe (ed.), p. 229-230.

161. Adelae Comitissae, inc.: "Vadis ut insolitos videas, mea cartula, fastos" (WALther, 1959, no. 19962): famous over 700 elegiac couplets for the tapestries in the Countess' chamber, ed. in Baudri de Bourgueil, Poèmes, J.-Y. Tilliette (ed.), p. 2-43, no. 134. On this work cf. Les ceuvres poétiques..., Ph. Abrahams (ed.), p. 196-231; Dronke, 1965, p. 210-212; Brooks and Walker, 1979, p. 26-29, J.-Y. Tilliette, 1981a; J.-Y. Tilliette, 1981b; van Houts, 1989, p. 49. The second text, Ad Adelam pro cappa quam sibi promiserat, inc.: "Quam peto, quam petii, si reddas, Adela, cappam" (WALTHER, 1959, no. 15157): 32 hexameters, ed. in BAUdRI De Bourgueil, Poèmes, J.-Y. Tilliette (ed.), p. 44-45, no. 135. On the verse cf. Les auvres poétiques..., Ph. Abrahams (ed.), p. 253; van Houts, 1989, p. 49.

162. Ceciliae regis Anglorum filiae, inc.: "Regia virgo, vale, vale, inquam, regia virgo" (WALther, 1959, no. 16508): 20 hexameters, ed. in Baudri de Bourgueil, Poèmes, J.-Y. Tilliette (ed.), p. 45, no. 136; cf. van Houts, 1989, p. 46.

163. Murieli, inc.: “Olim fama satis te magnificarat apud nos" (WALther, 1959, no. 3165): 23 elegiac couplets, in Wolff, 1996, p. 68-70, but also in Baudri de Bourgueil, Poèmes, J.-Y. Tilliette (ed.), p. 46-47, no. 137, and BALderico di Bourgueil, MARbodo di RenNes, Ildeberto di Lavardin, Lettere amorose e galanti, M. SANSON (ed.), p. 118-121 [but cf. also p. 139-140]; cf. BoutÉmY, 1935.

164. Dieudonné, 1898; BARTH, 1906; WAdDell, 1927, p. 97-116; RABY, 1927, p. 265-273; RABY, 1934, vol. I, p. 317-329; Scivoletto, 1954, p. 33-226; Moos, 1965; A.B. SCOTt, 1968; Orlandi, 1974; SzÖvÉRfFY, 1993, vol. II, p. 106-131; OrLANDI, 1997; Bertini, 2002, p. 221-225; BisAnti, 2005; ANgelini, 2006; ANGelini, 2012b.

165. Two poems, which bear the same title: Ad Adelam comitissam: the first one, inc.: "Desipit et peccat qui te mortalibus equat" (WALther, 1959, no. 4287): a distich, ed. in Hildebertus Cenomannensis episcopus, Carmina minora, A.B. Scott (ed.), p. 4, no. 10; the second text, inc.: "Augusti suboles, serie sublimis avorum" (WALther, 1959, no. 1754): 4 distichs, ed. in Hildebertus Cenomannensis episcopus, Carmina minora, Scott (ed.), p. 5, no. 15; on both verse cf. Dronke, 1965, p. 209-211; LATZKe, 1979, p. 56-57; van Houts, 1989, p. 50.

166. Epistolae I, 3 and 5, ed. in PL, vol. CLXXI, 1854, col. 144-149; Epistolae III, 2 and 8, ed. respectively in $P L$, vol. CLXXI, 1854, col. 284 and col. 288-289. It is more difficult, but not impossible, to find Adela behind the writing of Epistolae I, 6 (addressed in fact to an Adela comitissa) and I, 10, ed. respectively in $P L$, vol. CLXXI, 1854, col. 149-153 and col. 162-168. About these texts cf. ANGELINI, 2015, p. 171-173.

167. The poem, inc.: “Cum totus Blesis comitissam praedicet orbis" (WALTHER, 1959, no. 3852a): 23 hexameters, ed. in Boutémy, 1938, p. 126-127; cf. van Houts, 1989, p. 50.

168. The first of the two texts is Versus ad Ceciliam abbatissam Cathomi, inc.: "Qui solet ante homines Cicerone disertior esse" (WALTHER, 1959, no. 15668): 11 distichs, ed. in Hildebertus 
than once in his carmina minora for Matilda of Scotland. She was the recipient of four epistles ${ }^{169}$ and two verse encomia: a tetrastich ${ }^{170}$ and the central part of a poem on England ${ }^{171}$; there is no certainty that the Queen, rather than her homonymous daughter, is the dedicatee of a panegyric ${ }^{172}$.

As in Hildebert's poetry, Queen Matilda and, of course, also Henry I, were the main political focuses for other shadowy poets too. Some of them are unknown: they wrote praises ${ }^{173}$ and epitaphs ${ }^{174}$ for the Queen. Similarly, as for the King, besides an anonymous poem on peace and happiness in England during his reign ${ }^{175}$, there are two poets who shared the name Richard in addition to some unknown characters: regarding the former, Richardus de Belmeis ${ }^{176}$ (from Beaumais-sur-Dives in Normandy), Bishop of London until 1127, it is not clear whether he or rather his homonymous successor wrote a (now lost) Tractatus ad regem Henricum ritmice; the second one ${ }^{177}$, probably a monk from Worcester, composed only an obituary ${ }^{178}$ for the sovereign who died in 1135, or perhaps for his powerful nephew, Henri de Blois ${ }^{179}$, who later held the Winchester cathedral see during and beyond the Civil War, from 1129 to 1171.

Throughout this period of transition, although the deep-rooted influence of Northern France still remained very strong in politics and literature, there was

Cenomannensis episcopus, Carmina minora, A.B. Scott (ed.), p. 37, no. 46; cf. van Houts, 1989 , p. 46-47, 50. The other work is Ad Murielem litteratam, inc.: "Tempora prisca decem se iactavere Sibillis" (WALther, 1959, no. 19127): 14 elegiac couplets, ed. in Hildebertus Cenomannensis episcopus, Carmina minora, A.B. Scott (ed.), p. 17-18, no. 26; cf. Wilmart, 1937; SigNORI, 1995; CIZEK, 2005, p. 478-481.

169. Epistolae I, 7 and 9, ed. respectively in PL, vol. CLXXI, 1854, col. 153-157 and 160-162; Epistolae III, 11 and 12, ed. in PL, vol. CLXXI, 1854, col. 289-290. About all of these texts cf. Angelini, 2015, p. $173-175$.

170. Ad reginam Anglorum, inc.: "Inter opes et delicias populique favores" (WALther, 1959, no. 9473): 2 elegiac couplets, ed. in Hildebertus Cenomannensis episcopus, Carmina minora, A.B. Sсотт (ed.), p. 2, no. 4; cf. van Houts, 1989, p. 51.

171. De Anglia, inc.: "Anglia, terra ferax, tibi pax diuturna quietem" (WALther, 1959, no. 1022): 17 elegiac couplets, ed. in Hildebertus Cenomannensis episcopus, Carmina minora, A.B. Sсотт (ed.), p. 24-25, no. 37 [cf. in particular vv. 19-32]; cf. van HouTs, 1989, p. 51.

172. Ad Mathildem reginam, inc.: "Augustis patribus augustior orta Mathildis" (WALther, 1959, no. 1765): 13 elegiac couplets, ed. in HiLdebertus Cenomannensis episcopus, Carmina minora, A.B. ScOtT (ed.), p. 21-22, no. 35 and BisAnTI, 2005 [in particular, for the edition, p. 95]; on the identification of the dedicatee, cf. LATZKe, 1979, p. 50-52; van Houts, 1989, p. 51.

173. The poem, inc.: "Filia praeteriti, praesentis nupta, futuri" (WALTHER, 1959, no. 6509): 17 distichs, ed. among Hildebert's dubious Carmina miscellanea, in PL, vol. CLXXI, 1854, col. 1444; HAURÉAU, 1882, p. 135; cf. van Houts, 1989, p. 51.

174. Among the texts, transmitted by the main historiographers of the period, the poem, inc.: "Vivis, dum moreris, moriens, regina Mathildis" (WALTHER, 1959, no. 20753): a distich plus four hexameters, ed. in Boutémy, 1937, p. 305 in note; cf. van Houts, 1989, p. 51.

175. De Anglia et eius principe, inc.: "Anglia nunc humilis, terrarum gloria quondam" (WALther, 1959, no. 1014): 9 distichs, ed. among Hildebert's dubious Carmina miscellanea, in PL, vol. CLXXI, 1854, col. 1444; HauréAu, 1882, p. 134-135; cf. van Houts, 1989, p. 52.

176. Mason, John, 2004a (cf. NeININGER, 2004).

177. RigG, 1992, p. 32

178. Epitaphium, inc.: "Clerus pastore, monachus patre, plebs monitore" (WALTher, 1959, no. 2935): 31 hexameters (18 caudati and 3 final leonini), ed. in Wright, Thomas, 1846, p. 180-181.

179. Davis Henry, 1910; Voss, 1932; KING, 2004. 
an incipient reversal of this trend, which brought forward an increasing number of British authors, who then crossed the Channel. The great natural philosopher Adelard of Bath ${ }^{180}$, born ca. 1080, travelled first to Laon and Tours, where he wrote the earliest of his three Platonic styled dialogues (De eodem et diverso ${ }^{181}$, a protreptic prosimetrum), before leaving again for Southern Italy, Greece, Spain and West Asia. Then, in 1122, he returned to his Roman-English birthplace, where he died thirty years later. The main model is Boethius' Consolation of Philosophy, most of all for the contrast between Philocosmia, who advocates worldly pleasures, and Philosophia, whose defence of scholarship leads into a summary of the seven liberal arts.

Around the same period, a similar journey, this time straight to Normandy, was made by Orderic Vitalis ${ }^{182}$, born in England in 1075 to a French soldier: at the age of 10 he moved to Saint-Évroult abbey ${ }^{183}$ where he worked on his Historia Ecclesiastica ${ }^{184}$ until 1141 (presumably the year of death). This text, the main source for Anglo-Norman history, has numerous poetical passages ${ }^{185}$ : often anonymous encomia or epitaphs of bishops ${ }^{186}$ and other historical figures ${ }^{187}$. The historian was also a versifier himself, authoring about ten short mournful poems scattered throughout his work ${ }^{188}$, which is also important because of

180. Haskins, 1924, p. 20-42, 113-129, 346-355; Bliemetzrieder, 1935; MauraCh, 1982; Burnett, 1994; Cochrane, 1994; Lanza, 2000.

181. De eodem et diverso, ed. (and translated) in AdELARD of BAtH, Conversations with his Nephew, On the Same and the Different, Questions on Natural Science, and On Birds, Ch. Burnett (ed.), p. 1-79; Adelardo di Bath, L'identico e il diverso. De eodem et diverso, A. Bisanti and P. Palmeri (eds); cf. also Jolivet, 1981; Drew, 1987.

182. Pellerin, 1974b; Chibnall, 1984; Lettinck, 1984; MUSSet, 1984; Holdsworth, 1985; Hingst, 2009.

183. Cottineau, 1935-1937, vol. II, col. 2670-2671.

184. Historiae Normannorum Scriptores Antiqui, A. Du Chesne (ed.), p. 319-925 [reimpr. in PL, vol. CLXXVIII, 1855, col. 15-984] and The Ecclesiastical History of Orderic Vitalis, M. Chibnall (ed.). On this work cf. Delisle, 1903; Pellerin, 1974a; Chibnall, 1989; Chibnall, 1997; MÉgier, 2010.

185. The first one is an anonymous epigram, inc.: "Vinea culta fuit, cultores premia querunt" (WALTHER, 1959, no. 20357): 3 couples of hexameters rhymed in pairs, ed. in The Ecclesiastical History of Orderic Vitalis, M. Chibnall (ed.), book I, vol. I, p. 144.

186. 47 distichs, one for each bishop of Rouen, ed. in ibid., book V, vol. III, p. 16, 22, 50-62, 64-70, $74-80,84,86,88,92,94$.

187. 15 hexametrical or elegiac, often leonine epitaphs, from 5 to 15 lines (only 20 adonics for Hugo of Luxueil ed. in ibid., book V, vol. III, p. 18), transmitted in ibid., book VII, vol. IV, p. 44-46, 63-64, 164 [in particular on Matilda of Flander's obituary poem, inc. "Egregie pulchri tegit hec structura sepulchri" (WALTHER, 1959, no. 5280): 13 leonine hexameters, ed. in The Ecclesiastical History of Orderic Vitalis, M. Chibnall (ed.), vol. IV, p. 44-46, cf. van Houts, 1989, p. 46]; book VIII, ed. in The Ecclesiastical History of Orderic Vitalis, M. CHibnall (ed.), vol. IV, p. 180, 304, 310; book X, vol. V, p. 308, 332; book XI, vol. VI, p. 36, 146, 152, 172; book XII, vol. VI, p. 302, 312,378 .

188. Orderic's short poems are in hexameters and distichs, leonini and caudati, but even in little more unusual forms, such as paroxytone octosyllabes, and proparoxytone septenaries, in ibid., book IV, vol. II, p. 350; book V, vol. III, p. 168-169; book VI, vol. III, p. 256-257, 258, 336; book VIII, vol. IV, p. 144-146, 336; book IX, vol. V, p. 6-7, 166; book XI, vol. VI, p. 18-20, 142; book XII, vol. VI, p. 326; book XIII, vol. VI, p. 450, 488-90. 
the appearance of otherwise unknown poets ${ }^{189}$ : John of Rheims ${ }^{190}$, Odo of Montreuil ${ }^{191}$, Giroie Grossivus ${ }^{192}$, Peter Leonis ${ }^{193}$, Athelelm, monk of Fly ${ }^{194}$, who mostly wrote obituaries for members of Anglo-Norman church and court.

The almost contemporary William of Malmesbury ${ }^{195}$, born at some point between 1090 and 1095, was half-Norman through his father, although he spent the whole of his life in England, especially in his famous Wiltshire Abbey ${ }^{196}$, where he died around 1142. His historical pages also include numerous verses: in Gesta Regum Anglorum ${ }^{197}$ he records anonymous short obituaries ${ }^{198}$ as well as longer poems in versus heroici ${ }^{199}$. Only the epitaph for Emperor Henry III (or Lothair I, according to Karl Strecker ${ }^{200}$ ), includes a large number of very unusual lines ${ }^{201}$.

189. Even Audoen, bishop of Rouen, is quoted for a few lines, inc.: "Hi sunt Gildardus fratres geminique Medardus" (WALTHER, 1959, no. 7829): 3 leonine hexameters, transmitted by The Ecclesiastical History of Orderic Vitalis, M. Chibnall (ed.), book V, vol. III, p. 56.

190. Poem, inc.: "Post annos agni centum cum mille superni" (WALtheR, 1959, no. 14303): 11 mostly leonine hexameters for Peter, lord of Maule, in The Ecclesiastical History of Orderic Vitalis, M. Chibnall (ed.), book V, vol. III, p. 178.

191. Text of Ansold's epitaph, inc.: "Si quis erit qui scire velit dum vivus adesset" (Walther, 1959, no. 17924): 5 trinini salientes, in The Ecclesiastical History of Orderic Vitalis, M. ChibnaLl (ed.), book V, vol. III, p. 198.

192. Elegy, inc.: "Virtutum lampas qua pristina splenduit aetas" (WALther, 1959, no. 20618a): 3 couplets addressed to Gilbert Maminot, bishop of Lisieux, in The Ecclesiastical History of Orderic Vitalis, M. Chibnall (ed.), book VIII, vol. IV, p. 190.

193. He was the author of two, maybe three epitaphs: inc.: "Canonicum Remis, tulerat monachum Cluniacus Odonem" (WALtHER, 1959, no. 2367): 3 elegiac couplets on the death of pope Urban II, in The Ecclesiastical History of Orderic Vitalis, M. Chibnall (ed.), book X, vol. V, p. 192; more uncertain is the poem, inc.: "Canonicus Remensis Odo, quem Cluniacensis" (Walther, 1959, no. 2368): 8 distichs on the same Roman pontiff, in The Ecclesiastical History of Orderic Vitalis, M. Chibnall (ed.), book X, vol. V, p. 194; the last one, inc.: "Nec tibi Roma locum, nec dat Guitberte Ravenna" (WALTHER, 1959, no. 11702): 3 elegiac, obituary couplets on Guibert of Ravenna, in The Ecclesiastical History of Orderic Vitalis, M. ChibnaLl (ed.), book X, vol. V, p. 194.

194. Poem, inc.: "Utilitas et honor Guillelmus in ordine cleri" (WALTHER, 1959, no. 19927): 3 elegiac couplets on the death of William, abbot of Fécamp, in The Ecclesiastical History of Orderic Vitalis, M. Chibnall (ed.), book XI, vol. VI, p. 140.

195. Farmer, 1962; Thomson, 1978; Brown, 1982; Thomson, 1987; Wright, Neil, 1991b; Wright, Nigel, 1993; Winterbottom, 2001; Winterbottom, 2010; StOpPaCCI, 2015.

196. Cottineau, 1935-1937, vol. II, col. 1720.

197. Text ed. in Willelmi Malmesbiriensis monachi De Gestis Regum Anglorum Libri Quinque, W. Stubbs (ed.), and William of Malmesbury, Gesta Regum Anglorum. The History of the English Kings, R.A.B. Mynors (ed.), [in particular, on the author, vol. II, p. xxxv-xlvii].

198. The epitaphs in distichs or hexameters, seldom rhymed, are ed. in William of Malmesbury, Gesta Regum Anglorum..., R.A.B. Mynors (ed.), book I, chapters 24, 62, 85, vol. I, p. 94, 120, 810 (Appendix I); book II, chapter 194, vol. I, p. 192; book III, chapter 262, vol. I, p. 484; book V, chapter 439, vol. I, p. 784-786.

199. There are two poems of over thirty hexameters, ed. in William of Malmesbury, Gesta Regum Anglorum..., R.A.B. Mynors (ed.), book II, chapters 133, 135, vol. I, p. 210, 220-222.

200. Carmina varia, K. StReCKer (ed.), p. 1072-1075.

201. The verses are 28 (in a larger version 32) lines, each composed by half a hexameter and an adonic (a kind of metre which also Boethius used for the second poem in De Consolatione Philosophiae), ed. in William of Malmesbury, Gesta Regum Anglorum..., R.A.B. Mynors (ed.), book II, chapter 194, vol. I, p. 346-347. 
William's other texts incorporate many other poems. Most of them appear in the Gesta Pontificum Anglorum ${ }^{202}$, finished in 1125: the work quotes some pieces by famous early medieval versifiers ${ }^{203}$, in addition to those by the Malmesbury monk Peter Baldwin, who wrote in praise of the Tuscan abbot Faricius ${ }^{204}$. There is no doubt that the historian himself was the author of a few lines on Elgiva of Shaftesbury ${ }^{205}$, but the remaining verses are of doubtful attribution ${ }^{206}$ or anonymous ${ }^{207}$. The other texts, starting with the Saints' Lives ${ }^{208}$, show the same uncertain authorship ${ }^{209}$ in the cases of two epitaphs for Patrick ${ }^{210}$ and Benignus ${ }^{211}$.

202. Text ed. in William of Malmesbury, Gesta pontificum Anglorum. The History of the English Bishops, M. Winterbottom and R.M. Thomson (eds).

203. There are some short quotations from the works by Cuthbert of Canterbury, Aldhelm and Dunstan: texts in William of Malmesbury, Gesta pontificum Anglorum..., M. Winterbottom and R.M. Thомson (eds), book IV, chapter 162, vol. I, p. 454-456; book V, chapters 197, 255, vol. I, p. 520-522, 608 .

204. The poem, inc.: "Vir probus et prudens vir vere consiliorum" (WALtheR, 1959, no. 20418): 30 mostly rhymed hexameters, ed. in William of Malmesbury, Gesta pontificum Anglorum..., M. Winterbottom and R.M. Thomson (eds), book II, chapter 88, vol. I, p. 302-304.

205. The poem on Elgiva, inc.: "Nam nonnullis passa annis morborum molestiam": 8 verses $8 \mathrm{p}+7 \mathrm{pp}$, ed. in William of Malmesbury, Gesta pontificum Anglorum..., M. Winterbottom and R.M. Thomson (eds), book II, chapter 86, vol. I, p. 294.

206. The poem, inc.: "Ad superos superum cultor sociusque recessit" (WALTHER, 1959, no. 455): 3 distichs, ed. in William of Malmesbury, Gesta pontificum Anglorum..., M. Winterbottom and R.M. Tномson (eds), book V, chapter 227, vol. I, p. 572; the verse, inc.: "Hic iacet orbis honor, patriae dolor, orbita recti" (WALTHER, 1959, no. 7983): 3 distichs, ed. in William of Malmesbury, Gesta pontificum Anglorum..., M. Winterbottom and R.M. Thomson (eds), book V, chapter 246, vol. I, p. 594; two tetrastichs, respectively inc.: "Mortificare decet vitiis carnalia membra" (WALTHER, 1959, no. 11302), an innuendo expressed by an unknown enemy against Malmesbury abbey, and the probably William's retort, inc.: "Immo decet quocumque modo cohibere cadaver", ed. in William of Malmesbury, Gesta pontificum Anglorum..., M. Winterbottom and R.M. Thomson (eds), book V, chapter 271, vol. I, p. 648.

207. Only 4 verses from saint Cuthbert's antiphon, ed. in William of Malmesbury, Gesta pontificum Anglorum..., M. Winterbottom and R.M. Thomson (eds), book II, chapter 81, vol. I, p. 282-284; the epitaph for Iohannes Scotus Eriugena, inc.: "Clauditur hoc tumulo sanctus sophista Iohannes” (SCHALLER and KöNSGEN, 1977, no. 2573; WALTHER, 1959, nrr. 2866, 2869, 3127): a tetrastich, ed. in William of Malmesbury, Gesta pontificum Anglorum..., M. Winterвоттом and R.M. Thomson (eds), book V, chapter 240, vol. I, p. 588-590; the third strophe from the Hymnus de uno Confessore, inc.: "Iste confessor Domini sacratus" (SCHAller and KöNSGen, 1977, no. 8410): of the 6 sapphic stanzas ed. in Analecta Hymnica Medii Aevi, G.M. Dreves and C. Blume (eds), vol. LI, p. 134, the third, ed. in William of Malmesbury, Gesta pontificum Anglorum..., M. Winterbottom and R.M. Thomson (eds), book V, chapter 269 , vol. I, p. 638

208. Texts ed. in William of Malmesbury, Saints' Lives. Lives of SS. Wulfstan, Dungstan, Patrick, Benignus and Indract, M. Winterbottom and R.M. Thomson (eds), 2002.

209. The only exception is a couple of Dunstan's epigrams, respectivley inc.: "Organa do sancto presul Dunstanus Aldhelmo" (SChaller and KöNsgen, 1977, no. 11449) and "Idriolam hanc fundi Dunstan mandaverat archi": each of two leonine hexameters, ed. in William of Malmesbury, Saints' Lives..., M. Winterbottom and R.M. Thomson (eds), p. 258; cf. LAPIDGE, 1996, p. 510.

210. The text, inc.: "Calpurnus genuit istum, alma Britannia misit": two hexameters, ed. in William of Malmesbury, Saints' Lives..., M. Winterbottom and R.M. Thomson (eds), p. 336.

211. The text, inc.: "Hoc patris in lapide Beonnae sunt ossa locata": two hexameters, ibid., p. 354. 
Similarly, the Antiquitates Glastoniensis Ecclesiae record, besides some famous lines $^{212}$, a short verse by an unknown poet for Bishop Brithwold ${ }^{213}$.

For the Anglo-Norman Age the other major historian was Henry of Huntingdon ${ }^{214}$, who lived in Britain at about the same time as Orderic and William: in 1110, when he was not older than thirty, his father "bequeathed" the archdeaconry in the place from which they came; Normandy was regardless significant for him after he found some of the most important sources for his main work ${ }^{215}$ during a 1139 visit at Le Bec: the Historia Anglorum ${ }^{216}$, a prose narrative that contains many verses in the first ten books ${ }^{217}$. In six cases Henry translates lines from lost Anglo-Saxon verse (maybe a single poem) about English battles between the 7 th and 1oth centuries ${ }^{218}$; the poem about the fighting at Brunanburh (937) was translated into prose ${ }^{219}$, which had to reproduce the structure of the original vernacular form, using the same alliterations and rhyme.

The historian was nevertheless a competent poet himself, who placed eighteen poems in the prose of his major work, only some of which are signed ${ }^{220}$, even though it is very probable that he was the author of all eighteen ${ }^{221}$. All

212. Venantius Fortunatus' Carmen, III, 7, ed. in PL, vol. CLXXIX, 1855, col. 1704.

213. The piece, inc.: "Exiguus presul Brithwoldus onomate dictus" (WALther, 1959, no. 6072): 5 hexameters, in Antiquitates Glastoniensis Ecclesiae, ed. in PL, vol. CLXXIX, 1855, col. 1723.

214. Greenway, 1991, p. 43-50; RigG, 1992, p. 36-40; Gillingham, 1995; Greenway, 1996; Greenway, 2004.

215. Wright, Neil, 1991a.

216. Text ed. in Henry, Archdeacon of Huntingdon, Historia Anglorum. The History of the English People, D.E. Greenway (ed.).

217. Cf. ibid., p. cvii-cix.

218. Cf. RIGG, 1991 [in particular p. 64-65] on these short poems (from a single to 3 lines), ed. in HENRY, Archdeacon of Huntingdon, Historia Anglorum..., D.E. Greenway (ed.), book II, chapter 30 , p. 114; book II, chapter 34, p. 120; book III, chapters 33-34, p. 184-186; book III, chapter 39, p. 194; book IV, chapter 29, p. 262.

219. Cf. RIGG, 1991, p. 65-72, on edition, commentary and translation of the passage, also published in Henry, Archdeacon of Huntingdon, Historia Anglorum..., D.E. Greenway (ed.), book V, chapter 19, p. 314 .

220. Poems ed. ibid. Prologus, p. 6; book I, chapter 6, p. 20, two excerpts from an Encomium Britanniae, now lost for the remain; book V, chapters 13, 17, 26, p. 298, 308, 322; book VII, chapters 30, 36, 44, p. 462, 474, 492 [in particular chapter 30, p. 462: obituary for Queen Matilda, wife of King Henry, inc.: "Prospera non letam fecere nec aspera tristem" (WALTHER, 1959, no. 14845): 3 distichs, cf. van Houts, 1989, p. 51; chapter 44, p. 492: King Henry's epitaph, inc.: "Rex Henricus obit, decus olim, nunc dolor orbis" (WALTHER, 1959, no. 16731): 5 elegiac couplets, cf. van Houts, 1989, p. 52]; Henry, Archdeacon of Huntingdon, Historia Anglorum..., D.E. Greenway (ed.), book X, chapter 12 and 40, p. 724 and 776.

221. Cf. MaAZ, 1983, p. 113-120. This is the opinion expressed in Henry, Archdeacon of Huntingdon, Historia Anglorum..., D.E. Greenway (ed.), p. cviii-cix about the texts ed. at book II, chapter 33, p. 120 ; book VII, chapter 27 , p. 458 , an obituary for the poet's father, Nicholas of Huntingdon, inc.: "Stella cadit cleri, splendor marcet Nicholai" (WALTHER, 1959, no. 18593): a leonine distich; Henry, Archdeacon of Huntingdon, Historia Anglorum..., D.E. Greenway (ed.), book VII, chapter 31, p. 464: epinicion for King Henry's victory at Brémule, 20 August 1119, inc.: "Henricus regum rex et decus abstulit altos" (WALTHER, 1959, no. 7702): 8 hexameters, cf. vAN HouTs, 1989, p. 52-53; Henry, Archdeacon of Huntingdon, Historia Anglorum..., D.E. Greenway (ed.), book VII, chapter 32, p. 466, a lamentation for the sinking of the White Ship in 1120, inc.: "Dum 
of these, and a few other (mostly anonymous) verses ${ }^{222}$ are epica or historica carmina, epitaphia and encomia (a shadowy Walo Brito ${ }^{223}$ might have written an obituary for William Clito, son of Robert Curthose ${ }^{224}$ ).

In the final part of the History ${ }^{225}$, Henry says that he had written many other verses: the majority of them, the Epigrammatorum iocundorum libri $6^{226}$ about love, are now lost; instead the collection Epigrammata seria forms the final portion of the Historia Anglorum, books XI and XII ${ }^{227}$, composed of $26^{228}$ and 10 poems ${ }^{229}$ respectively. In this context, the author shows his complete

Normannigene Gallis clari superati" (WALTHER, 1959, no. 4911): 3 mournful distichs, cf. van Houts, 1989, p. 52; Henrry, Archdeacon of Huntingdon, Historia Anglorum..., D.E. Greenway (ed.), book VII, chapter 33, p. 468, an encomium of Adeliza of Louvain, second wife of King Henry I, inc.: "Anglorum regina tuos, Adelida, decores" (WALther, 1959, no. 1040): 5 distichs, that van Houts, 1989, p. 51-52, assigns to Hildebert of Le Mans; Henry, Archdeacon of Huntingdon, Historia Anglorum..., D.E. GreEnway (ed.), chapter 34, p. 470, epitaph for Robert, bishop of Lincoln inc.: "Pontificum Rodbertus honor, quem fama superstes" (WALTHER, 1959, no. 14261): 4 distichs; HenRY, Archdeacon of Huntingdon, Historia Anglorum..., D.E. Greenway (ed.), book VIII, at the end of the letter on the contempt for the world, chapter 19, p. 618; ibid., book X, chapter 33, p. 760 .

222. The epitaph for pope Gregory the Great, inc.: "Suscipe terra tuo corpus de corpore sumptum" (WALTHER, 1959, no. 18952): 5 distichs, partly taken from Bede’s Historia Ecclesiastica Gentis Anglorum II, 1, ed. in Henry, Archdeacon of Huntingdon, Historia Anglorum..., D.E. Greenway (ed.), book III, chapter 12, p. 16o; the already mentioned leonine hexameters, inc.: "Anno milleno sexageno quoque seno", and the distich, inc.: "Caesariem, Caesar, si tibi Natura negavit" (Walther, 1959, no. 2297) ed. in Henry, Archdeacon of Huntingdon, Historia Anglorum..., D.E. Greenway (ed.), book VI, chapters 30, 41, p. 394, 410; an excerpt, inc.: "Bella Maro resonet, nos paucis dona canamus", 14 distichs, taken from Bede's acrostic of 54 lines in Historia Ecclesiastica Gentis Anglorum IV, 18, ed. in Henry, Archdeacon of Huntingdon, Historia Anglorum..., D.E. Greenway (ed.), book IX, chapter 34, p. 664.

223. Cf. ed. ibid., Appendix I, p. 836.

224. The poem, inc. "Mars obit in terris, deflent per sydera sydus" (Walther, 1959, no. 10706): 5 distichs, ed. in Henry, Archdeacon of Huntingdon, Historia Anglorum..., D.E. Greenway (ed.), Appendix I, p. 837 (but cf. also p. 482); cf. van HouTs, 1989, p. 46.

225. Cf. ed. in Henry, Archdeacon of Huntingdon, Historia Anglorum..., D.E. Greenway (ed.), book XII, prologus, p. 804

226. Cf. ibid., p. cx, cxii-cxv.

227. Cf. ibid., p. cix-cxii.

228. Texts ed. in The Anglo-Latin Satirical Poets..., Th. Wright (ed.), p. 163-174, and in Henry, ArChDEACon of Huntingdon, Historia Anglorum..., D.E. Greenway (ed.), book XI, p. 778-802. All of the poems are in hexameters and distichs, except for p. 778-78o, no. 1, De veritate libri, inc.: "Otia luxuriam docent, otia livorem movent" (WALTHER, 1959, no. 13534): each of the verses 1-12 is formed by the first half of a hexameter plus an iamb, repeated; lines 13-14 are hexameters; HeNRY, Archdeacon of Huntingdon, Historia Anglorum..., D.E. Greenway (ed.), p. 780-784, no. 2, Satira communis, inc.: "Scribimus hec clero: vos non latrare valentes" (WALTHER, 1959, no. 17402): 74 hexameters rhyming in pairs or, at verses 57-60, with alternate rhyme; HeNRY, ARCHDEACON of Huntingdon, Historia Anglorum..., D.E. Greenway (ed.), p. 784, no. 5, Ad lectorem, inc.: "Non homicida sis, nec adulter" (Walther, 1959, no. 5556): 4 repeated adonics; Henry, Archdeacon of Huntingdon, Historia Anglorum..., D.E. Greenway (ed.), p. 794-796, no. 19, De pressura Anglie, inc.: "Non homicida sis, nec adulter" (WALTHER, 1959, no. 7029): 16 repeated adonics.

229. Texts ed. in Henry, Archdeacon of Huntingdon, Historia Anglorum..., D.E. Greenway (ed.), book XII, p. 804-825. All of the poems are in hexameters and distichs, except for: p. 810, no. 2, Laus Dei, inc.: "Cantemus Domino carmina glorie": 3 stanzas of three lesser Asclepiads and one glyconic; p. 814-816, no. 7, De amore virtutis, inc.: "Balsama quod spirant recenter acta": metrical 
poetical ability, using all sorts of metres: distichs and hexameters, often with disyllabic rhyme, and lesser asclepiads, glyconics, adonics and iambs. The wide range of themes goes from the topics (in particular death, the inconsistency and the contempt of the world) of the Roman poet Martial to religious subjects: not only ecclesiastical corruption and simony, but also personal prayers, hymns and metrical versions of Biblical narratives.

The great skill of Henry as a poet has recently emerged, by the discovery in manuscripts of a great deal of poems once considered lost: a composite work ${ }^{230}$ in verse on plants and precious stones has finally been found and edited, with the result that more than 3300 lines of the most prolific author of that time are now available.

A consideration of all of Henry's work reveals a large variety of poetic compositions, especially from a technical point of view. As for the subjects, he ranges from historical to medical topics. Regardless, poetry had a very special place in his output, with some outstanding texts: especially encomia and epitaphs of British sovereigns, from the VII century to King Henry I, his two wives, Matilda and Adela, until his homonymous nephew and successor, the first Plantagenet king $^{231}$. But that, as is often said, is another story.

\section{Bibliography}

\section{Sources}

Acta Sanctorum quotquot toto orbe coluntur [AASS], Jean Bolland, Godefroid Henschenius et al. (eds), Antwerp - Tongerlo - Brussels - Paris, I. Meursius, 1643-1940.

Adelard of Bath, Conversations with his Nephew, On the Same and the Different, Questions on Natural Science, and On Birds, Charles BurnetT (ed. and trad.), Italo Ronca, Pedro Mantas España and Baudouin Van den Abeele (adiuv.), Cambridge, Cambridge University Press (Cambridge Medieval Classics, 9), 1998.

experiment, made by a hemiepes plus an iambic metron and a final syllable, cf. RIGG, 1991, p. 62; Henry, Archdeacon of Huntingdon, Historia Anglorum..., D.E. Greenway (ed.), p. 824, no. 10, Oratio Henrici in mortem vel post mortem, inc.: "Summe Deus, fero digna reus: miserere fatentis" (WALtheR, 1959, no. 18770): 5 trinini salientes, rhyming in couplets aac ccb dde ffe ggh.

230. Anglicanus ortus is the title chosen by modern scholars to indicate collectively the three parts found in the mss Cambridge, Trinity College O.9.10 (1422); London, British Library, Sloane 3468; Oxford, Bodleian Library, Digby 13 (S.C. 1614); Oxford, Bodleian Library, Digby 69 (S.C. 1670); Praha, Archiv Prazského Hradu, Knihovna Metropolitní Kapituly M. VI (1359). The single sections of the whole are separately ed. by RIGG, 2003 [partial edition of the 8 books of $D e$ herbarum virtute; cf. also Ruppel, 1997; GreEnWAY, 2005]; BLACK, 2006 [edition of De gemmis preciosis, 35 hexametrical poems]; Henry of Huntingdon, Anglicanus ortus. A Verse Herbal of the Twelfth Century, W. BLACK (ed.), 2012 [new edition of 6 among the 8 books of De herbarum virtute, together with the third part of the composite poem: De aromatibus].

231. KeEFE, 2004. 
Adelardo di Bath, L'identico e il diverso. De eodem et diverso, Armando Bisanti and Pietro Palmeri (eds and trad.), Palermo, Officina di Studi Medievali (Machina philosophorum, 12), 2014.

Analecta Hymnica Medii Aevi, Guido Maria Dreves and Clemens Blume (eds), Leipzig, Reisland, 1886-1926, 55 vols.

Annales Ordinis S. Benedicti, Jean Mabillon (ed.), Lucca, L. Venturini, 1739-1745, 6 vols.

Balderico di Bourgueil, Marbodo di Rennes, Ildeberto di Lavardin, Lettere amorose e galanti, Manuela SAnson (ed. and trad.), Roma, Carocci (Biblioteca Medievale, 100), 2005.

Baudri de Bourgueil, Poèmes, Jean-Yves Tilliette (ed. and trad.), vol. II, Paris, Les Belles Lettres (Auteurs latins du Moyen Âge, 12), 2002.

Beati Lanfranci Cantuariensis Archiepiscopi Opera omnia, Luc d'Achery (ed.), Paris, J. Billaine, 1648.

Bibliotheca Hagiographica Latina antiquae et mediae aetatis, Socii Bollandiani (eds), Bruxelles, Société des Bollandistes, 1898-1901, 2 vols.

Carmina Leodiensia, Walther Bulst (ed.), Heidelberg, C. Winter (Sitzungsberichte der Heidelberger Akademie der Wissenschaften. Philosophisch-historische Klasse, 1975/1), 1975.

Carmina varia, Karl Strecker (ed.), in Monumenta Germaniae Historica. Poetae Latini Aevi Carolini, vol. IV/2-3, Berlin, Weidmann, 1823, p. 1072-109o.

Chroniques anglo-normandes. Recueil d'extraits et d'écrits relatifs à l'histoire de Normandie et d'Angleterre pendant les XI et XII siècles, Francisque Michel (ed.), vol. III, Rouen, E. Frère, 1840.

Chroniques des églises d'Anjou, Paul Marchegay and Émile Mabille (eds), Paris, J. Renouard, 1869.

EAdmer of CAnterbury, Lives and miracles of saints Oda, Dunstan, and Oswald, Andrew, J. Turner and Bernard J. Muir (eds and trad.), Oxford, Clarendon Press (Oxford medieval texts), 2006.

EAdmeri Historia Novorum in Anglia, Martin Rule (ed.), London, Longman (Rerum Britannicarum Medii Aevi Scriptores, or Chronicles and Memorials of Great Britain and Ireland during the Middle Ages, 81), 1884.

Guglielmo il Pugliese, Le gesta di Roberto il Guiscardo, Rosario Leotta (ed. and trad.), Emanuele CAstorina (praef.), Catania, Giannotta, 1977.

Guilielmi Appuli Historicum poema de rebus Normannorum in Sicilia, Appulia, et Calabria gestis, Ludovico Antonio Muratori (ed.), in Rerum Italicarum Scriptores, vol. V, Milano, ex Typographia Societatis Palatinae in Regia Curia, 1724, p. 253-278.

Guilielmi Neubrigensis Historia, Thomas Hearne (ed.), vol. III, Oxford, e theatro Sheldoniano, 1719.

Guillaume de Pouille, La Geste de Robert Guiscard, Marguerite Mathieu (ed. and trad.), Palermo, Istituto Siciliano di Studi Bizantini e Neoellenici (Testi e monumenti. Testi, 4), 1961.

Guillelmi Apuliensis Rerum in Italia ac Regno Neapolitano Normanicarum libri quinque, Joannis Tiremaeus (ed.), Rouen, R. Petit et R. l'Allemant, 1582.

Tabularia «Études», «Autour de Serlon de Bayeux...», 2018, p. 1-54, 10 septembre 2018 
Guillermi Apuliensis Gesta Roberti Wiscardi, Roger Wilmans (ed.), in Monumenta Germaniae Historica. Scriptores, vol. IX, Hannover, Hahn, 1851, p. 241-298.

Guillielmi Apuliensis Rerum in Apulia, Campania, Calabria et Sicilia Normanicarum libri quinque, Iohannes Baptista CARusIus (ed.), in Bibliotheca historica Regni Siciliae, sive Historicorum, qui de rebus siculis a Saracenorum invasione usque ad Aragonensium principatum illustriora monumenta reliquerunt, amplissima collectio, vol. I, Palermo, F. Cichè, 1723, p. 91-149.

Guy of Amiens, The "Carmen de Hastingae proelio" of Guy Bishop of Amiens, Frank BArlow (ed. and trad.), Oxford, Clarendon Press (Oxford Medieval Texts), $1999^{2}$.

Guy of Amiens, The "Carmen de Hastingae proelio" of Guy Bishop of Amiens, Catherine Morton and Hope Muntz (eds and trad.), Oxford, Clarendon Press (Oxford Medieval Texts), 1972.

Henry, Archdeacon of Huntingdon, Historia Anglorum. The History of the English People, Diana E. Greenway (ed. and trad.), Oxford, Clarendon Press (Oxford Medieval Texts), 1996.

Henry of Huntingdon, Anglicanus ortus. A Verse Herbal of the Twelfth Century, Winston Black (ed. and trad.), Toronto, Pontifical Institute of Mediaeval Studies (Studies and Texts, 180), 2012.

Herman the Archdeacon and Goscelin of Saint-Bertin, Miracles of St Edmund, Tom Licence (ed. and trad.), Lynda Locker (adiuv.), Oxford, Clarendon Press (Oxford Medieval Texts), 2014.

Hildebertus Cenomannensis episcopus, Carmina minora, Alexander Brian Sсотт (ed.), Leipzig-München, K.G. Saur (Bibliotheca Scriptorum Graecorum et Romanorum Teubneriana), 1969 [2001²].

Histoire littéraire de la France, par des religieux bénédictins de la congrégation de S. Maur (dom Antoine Rivet de la Grange, dom Charles-Louis Taillandier et dom Charles ClémenCET, continuée par des membres de l'Institut, Académie des Inscriptions et Belles-Lettres), Paris, Imprimerie nationale, V. Palmé, puis Firmin-Didot, puis Impr. nationale, puis De Boccard, 1733-1893.

Historiae Normannorum Scriptores Antiqui, André Du Chesne (ed.), Paris, R. Fouet, 1619.

Hugh the Chanter, The History of the Church of York: 1066-1127, Charles Johnson (ed. and trad.), London, Nelson (Medieval Texts), 1961 [reimpr. ed., revised by Martin Brett, Christopher N.L. Brooke and Michael Winterbottom, Oxford, Clarendon Press (Oxford Medieval Texts), 1990].

Jezebel. A Norman Latin Poem of the Early Eleventh Century, Jan M. Ziolkowski (ed.), New York - Bern - Frankfurt a.M. - Paris, P. Lang (Humana civilitas, 10), 1989.

Les cuvres poétiques de Baudri de Bourgueil (1046-1130), Phyllis Aвrahams (ed.), Paris, H. Champion, 1926.

Lives of Edward the Confessor I, Henry Richard LuARD (ed.), [I La Estoire de Seint Aedward le Rei; II Vita Beati Edvardi Regis et Confessoris; III Vita Aeduuardi Regis qui Apud Westmonasterium Requiescit], London, Longman, Brown, Green and Co. (Rerum Britannicarum Medii Aevi Scriptores, 3), 1858. 
Marbodo di Rennes, De ornamentis verborum - Liber decem capitulorum. Retorica, mitologia e moralità di un vescovo poeta (secc. XI-XII), Rosario LeOtTA (ed. and trad.), Carmelo Crimi (ed.), Firenze, SISMEL. Edizioni del Galluzzo (Fondazione Ezio Franceschini. Per verba. Testi mediolatini con traduzione, 10) 1998.

Memorials of Saint Dunstan, Archbishop of Canterbury, William STUввs (ed.), London, Longman (Rerum Britannicarum Medii Aevi Scriptores, 63), 1874.

Neustria pia, seu de omnibus et singulis abbatiis et prioratibus totius Normaniae, Arthur Du Monstier (ed.), Rouen, J. Berthelin, 1663.

Patrologiae latinae cursus completus [PL], Jacques-Paul Migne (ed.), Paris, Migne, 1844-1864, 221 vols.

Recueil des actes des ducs de Normandie de 911 à 1066, Marie Fauroux (ed.), Caen, Caron, 1961.

Recueil des historiens des Gaules et de la France (= Rerum Gallicarum et Francicarum Scriptores), dom Martin BouQuet (ed.), Académie des Inscriptions et Belles-lettres, vol. II, Paris, Palmé, 1739.

Recueil des rouleaux des morts (VIIII ${ }^{e}$ siècle-vers 1536), Jean Dufour (ed.), Paris, Académie des Inscriptions et Belles-Lettres (Recueil des historiens de la France. Obituaires. Série in-4, 8), 2005-2013, 5 vols.

Rouleaux des morts du IX au XV siècle, Léopold Delisle (ed.), Paris, Renouard (Publications pour la Société de l'histoire de France, 135), 1866.

Sancti Anselmi ex Beccensi abbate Cantuariensis archiepiscopi Opera, Gabriel Gerberon (ed.), Paris, L. Billaine and J. du Puis, 1675.

Scriptores rerum gestarum Willelmi Conquestoris, John Allen GiLes (ed.), London, D. Nutt, 1845

Serlo of Bayeux, De capta Baiocensium civitate, Moreed Arbabzadah (ed. and trad.), in VAN Houts, 2013, Appendix 3, p. 86-91.

Serlo of BAyeux, Defensio pro filiis presbyterorum, Ernst DüMmLER and Heinrich BöHMER (eds), in Monumenta Germaniae Historica. Libelli de lite imperatorum et pontificum saeculis XI et XII conscripti, vol. III, Hannover, Hahn, 1897, p. 579-583.

SERlon de Wilton, Poèmes latins, Jan ÖBERG (ed.), Stockholm - Göteborg - Uppsala, Almqvist and Wiksell (Acta universitatis Stockholmiensis. Studia Latina Stockholmiensia, 14), 1965.

Spicilegium sive collectio veterum aliquot scriptorum qui in Galliae bibliothecis delituerant, Luc d'Achery (ed.), vol. IV, Paris, Montalant, 1723.

STEPHANi BALUZII miscellaneorum liber primus [-septimus], hoc est Collectio veterum monumentorum quae hactenus latuerant in variis codicibus ac bibliothecis, Paris, F. Muguet, 1678-1715, 7 vols.

The Anglo-Latin Satirical Poets and Epigrammatists of the Twelfth Century, Thomas Wright (ed.), vol. II, London, Longman and Trübner (Rerum Britannicarum Medii Aevi Scriptores or Chronicles and Memorials of Great Britain and Ireland during the Middle Ages, 59, 2), 1872.

The Ecclesiastical History of Orderic Vitalis, Marjorie Chibnall (ed. and trad.), Oxford, Clarendon Press (Oxford Medieval Texts), 1969-1980, 6 vols. 
The Historians of the Church of York and Its Archbishops, James RAINE (ed.), vol. II, London, Longman (Rerum Britannicarum Medii Aevi Scriptores, 71), 1886.

The Life of King Edward Who Rests at Westminster, Attributed to a Monk of Saint-Bertin (= Vita Aedwardi Regis qui apud Westmonasterium requiescit / S. Bertini monacho ascripta), F. BARLow (ed. and trad.), London, T. Nelson (Medieval Texts), 1962.

The Life of Saint Anselm, Archbishop of Canterbury, by Eadmer, Richard William SOUTHERN (ed. and trad.), London, T. Nelson, 1962.

The Works of Gilbert Crispin Abbot of Westminster, Anna Sapir Abulafia and Gillian Rosemary Evans (eds), London, Oxford University Press (Auctores Britannici Medii Aevi, 8), 1986.

Three Treatises from Bec on the Nature of Monastic Life, Giles Const ABLE (ed.), Bernard S. Sмiтн (trad.), Toronto, Buffalo, London, University of Toronto, 2008.

Veterum analectorum tomus II, Jean MABILlon (ed.), Paris, L. Billaine, 1676.

Veterum scriptorum et monumentorum moralium, historicorum, dogmaticorum ad res ecclesiasticas, monasticas et politicas illustrandas collectio nova, Edmond Martìne (ed.), Paris, J. Boudot, 1700, 2 vols.

Warner of Rouen, Moriuht. A Norman Latin Poem of the Early Eleventh Century, Christopher James McDonough (ed. and trad.), Toronto, Pontifical Institute of Mediaeval Studies (Studies and Texts, 121), 1995.

Willelmi Malmesbiriensis monachi De Gestis Regum Anglorum Libri Quinque, William Stubвs (ed.), London, Eyre and Spottiswoode (Rerum Britannicarum Medii Aevi Scriptores, 90), 1887-1889, 2 vols.

William of Malmesbury, Gesta pontificum Anglorum. The History of the English Bishops, Michael Winterbotтom and Rodney M. Thomson (eds and trad.), Oxford, Clarendon Press (Oxford Medieval Texts), 2007, 2 vols.

William of Malmesbury, Gesta Regum Anglorum. The History of the English Kings, Roger Aubrey Baskerville Mynors (ed. and trad.), Rodney Malcom Thomson and Michael Winterbotтom (adiuv.), Oxford, Clarendon Press (Oxford Medieval Texts), 1998-1999, 2 vols.

William of Malmesbury, Saints' Lives. Lives of SS. Wulfstan, Dungstan, Patrick, Benignus and Indract, Michael Winterbottom and Rodney M. Thomson (eds and trad.), Oxford, Clarendon Press (Oxford Medieval Texts), 2002.

\section{Studies}

Aird, William M., Robert Curthose Duke of Normandy, Woodbridge, Boydell Press (Harvard Historical Studies, 25), 2008.

Albu, Emily, The Normans in their Histories: Propaganda, Myth, and Subversion, Woodbridge, Boydell Press, 2001.

Allen, Richard, “Avant Lanfranc. Un réexamen de la carrière de Mauger, archevêque de Rouen (1037-1054/55)", in Autour de Lanfranc (1010-2010). Réforme et réformateurs dans l'Europe du Nord-Ouest (XI ${ }^{e}-X I I^{e}$ siècles), Julia BARrow, Fabrice Delivré and Véronique Gazeau (eds), Caen, Presses universitaires de Caen, 2015, p. 131-152. 
Alexander, James W., "Herbert of Norwich 1091-1119: Studies in the history of Norman England", Studies in Medieval and Renaissance History, 6, 1969, p. 115-232.

Angelini, Roberto, “Alter Ovidius o consarcinator? Bilancio delle prospettive di interpretazione e nuove proposte di studio su Ildeberto di Lavardin", Filologia mediolatina, 13, 2006, p. 215-227.

AngelinI, Roberto, "Folcardus Sancti Bertini monachus", in C.A.L.M.A., vol. III/3, 2010, p. 367.

Angelini, Roberto, "Fulcoius Bellovacensis", in C.A.L.M.A., vol. III/5, 2011, p. 601-603.

Angelini, Roberto, "Gaufridus Remensis”, in C.A.L.M.A., vol. IV/1, 2012, p. 119-12o.

Angelini, Roberto, Le poesie "dubbie" di Ildeberto di Lavardin: esame della tradizione manoscritta e proposta di attribuzione, $\mathrm{PhD}$ Thesis, Firenze, Università degli Studi, Dipartimento di Medioevo e Rinascimento, 2012.

Angelini, Roberto, “Guillelmus Apuliensis”, in C.A.L.M.A., vol. IV/5, 2014, p. 588-589.

Angelini, Roberto, "Powerful women in the epistles of Hildebert of Lavardin", in Medieval Letters between Fiction and Document, Siena 9-11 September 2013, Elisabetta BARtoli and Christian Høgel (eds), Francesco Stella and Lars Boje Mortensen (praef.), Turnhout, Brepols (Utrecht Studies in Medieval Literacy, 33), 2015, p. 167-178.

Angelini, Roberto and LAPIDGe, Michael, "Guillelmus Bona Anima”, in C.A.L.M.A., vol. IV/5, 2014, p. 607 .

ArbabzadAh, Moreed, “Textual errors in Serlo of Bayeux's poem about the capture of Bayeux”, Tabularia [On line], Autour de Serlon de Bayeux: la poésie normande aux $X I^{e}$-XII ${ }^{e}$ siècles. URL: http://journals.openedition.org/tabularia/2951.

ArchibAld, Elizabeth, "Sex and power in Thebes and Babylon: Oedipus and Semiramis in classical and medieval texts", Journal of Medieval Latin, 11, 2001, p. 27-49.

Auctoritas und Ratio. Studien zu Berengar von Tours, Peter GAnz, Robert B.C. Huygens and Friedrich NiewöHner (eds), Wiesbaden, Harrassowitz (Wolfenbütteler Mittelalter-Studien 2), 1990.

BARLOW, Frank, William I and the Norman Conquest, London, English Universities Press, 1965.

Barlow, Frank, "The Carmen de Hastingae Proelio", in Studies in International History presented to W. Norton Medlicott, Kenneth Bourne and Donald Cameron WАтт (eds), London, Longmans, 1967, p. 36-67.

BARLOw, Frank, Edward the Confessor, London, Eyre and Spottiswoode, 1970.

BARLOw, Frank, The English Church 1066-1154: A History of the Anglo-Norman Church, London - New York, Longman, 1979.

BARLOW, Frank, William Rufus, London, Methuen, 1983.

BARLOw, Frank, "Edward [St Edward; known as Edward the Confessor] (1003X5-1066)", in Oxford Dictionary, 2004a, vol. XVII, p. 785-792.

BARLOW, Frank, "William II [Known as William Rufus]”, in Oxford Dictionary, 2004b, vol. LIX, p. 64-73.

BArrow, Julia, “Herrmann (d. 1078)”, in Oxford Dictionary, 2004, vol. XXVI, p. 786 787. 
BARTH, Franz Xaver, Hildebert von Lavardin (1056-1133) und das kirchliche Stellenbesetzungsrecht, Stuttgart, F. Enke (Kirchenrechtliche Abhandlungen, 34-36), 1906.

BAтсоск, Neil, "The parish church in Norfolk in the eleventh and twelfth centuries", in Minsters and Parish Churches. The Local Church in Transition 950-1200, John BLAIR (ed.), Oxford, Oxford University Committee for Archaeology (Monograph, 17), 1988, p. 179-190.

BAte, Alan Keith, "Les Normands et la littérature au début du nouveau millenium", Cahiers de civilisation médiévale, 43, 2000, p. 233-241.

BAtes, David, “The character and career of Odo, bishop of Bayeux (1049/50-1097)", Speculum, 50, 1975, p. 1-20.

Bates, David, William the Conqueror, New Haven, CT - London, Yale University Press, 2016.

BAtEs, David, "Le patronage clérical et intellectuel de l'évêque Odon de Bayeux, 1049/50-1097", in Chapitres et cathédrales en Normandie: Actes du XXXI congrès des sociétés historiques et archéologiques de Normandie Mortagne-au-Perche 16-20 oct. 1996, Sylvette Lemagnen and Philippe Manneville (eds), Caen, Musée de Normandie (Annales de Normandie. Série des congrès des sociétés historiques et archéologiques de Normandie, 2), 1997, p. 105-114.

BAtes, David “Odo, earl of Kent (d. 1097)”, in Oxford Dictionary, 2004a, vol. XLI, p. 500-503.

BATES, David, "William I (1027/8-1087)", in Oxford Dictionary, 2004b, vol. LIX, p. 45-57.

Baudot, Jules and Chaussin, Léon, Vies des saints et des bienheureux selon l'ordre $d u$ calendrier avec l'historique des fêtes, vol. IX, Paris, Letouzey et Ané, 1950.

Bauduin, Pierre, La première Normandie ( $X^{e}-X I^{e}$ siècle). Sur les frontières de la haute Normandie: identité et construction d'une principauté, Régine Le JaN (praef.), Caen, Presses universitaires de Caen (Bibliothèque du Pôle universitaire normand), 2004.

Beare, Rhona, "Did Goscelin write the earliest Life of Edward the Confessor?", Notes and Queries, 55, 2008, p. 262-265.

BeHREnds, Frederick, "Berengar of Tours, Fulbert of Chartres and Fulbertus Exiguus", Revue Bénédictine, 85, 1975, p. 333-347.

Bertini, Ferruccio, Letteratura latina medievale in Italia (secoli V-XIII), Busto Arsizio (Varese), Bramante, 1988.

Bertini, Ferruccio, "Il secolo XI", in Letteratura latina medievale. Secoli VI-XV. Un manuale, Claudio Leonardi (ed.), Firenze, SISMEL Edizioni del Galluzzo (Millennio Medievale, 31. Strumenti e Studi. Nuova Serie, 2), 2002, p. 174-230.

Bezzola, Reto Radoulf, Les origines et la formation de la littérature courtoise en Occident (500-1200), II, La société féodale et la transformation de la littérature de cour, Paris - Genève, H. Champion (Bibliothèque de l'École des hautes études, 319-320), 1960.

Biffi, Inos, “Anselmo arcivescovo e monaco: le tribolazioni per la libertas Ecclesiae. L'azione pastorale. Il tramonto a Canterbury”, in Biffi, Protagonisti del medioevo. Anselmo e Lanfranco, Urbano II, Sugero, Pietro Il Venerabile, Tommaso Becket, Milano, Jaca Book (Biblioteca di cultura medievale. Di fronte e attraverso, 411), 1996, p. 109-198. 
BISANTI, Armando, “Ildeberto di Lavardin. Vita, opere, problemi attributivi”, Quaderni medievali, 59, 2005, p. 310-328.

Bisanti, Armando, "Composizione, stile e tendenze dei Gesta Roberti Wiscardi di Guglielmo il Pugliese”, Archivio Normanno-Svevo, 1, 2008, p. 87-132.

BisAnTI, Armando, "Sul carme 35 (Ad M<athildem reginam $>$ ) di Ildeberto di Lavardin", in "Res perinde sunt ut agas". Scritti per Gianna Petrone, Armando BisAnti and Aldo Casamento (eds), Palermo, Istituto Poligrafico Europeo (La ferza e il paleo, 1), 2010, p. 85-114.

Black, Winston, “Henry of Huntingdon's lapidary rediscovered and his Anglicanus ortus reassembled", Mediaeval Studies, 68, 2006, p. 43-87.

Bliemetzrieder, Franz Plazidus, Adelhard von Bath: Blätter aus dem Leben eines englischen Naturphilosophen des XII. Jahrhunderts und Bahnbrechers einer Wiedererweckung der griechischen Antike, München, M. Hueber, 1935.

BöHMER, Heinrich, "Der sogenannte Serlo von Bayeux und die ihm zugeschriebenen Gedichte", Neues Archiv, 22, 1897, p. 703-738.

Bon, Bruno, Index Scriptorum Novus Mediae Latinitatis. Supplementum (1973-2005), Genève, Droz, 2005.

Bond, Gerald, "Iocus amoris: The Poetry of Baudri of Bourgueil and the Formation of the Ovidian Subculture", Traditio, 42, 1986, p. 143-193.

Bottini Massa, Enrico, Il poema di Guglielmo Pugliese sulle gesta dei Normanni in Italia, Bologna, Pongetti, 1889.

BoüARD, Michel de, "Notes et hypothèses sur Maurille moine de Fécamp, et son élection au siège métropolitain de Rouen", in L'abbaye bénédictine de Fécamp, Fécamp, L. Durand et fils, 1959, p. 81-92, 351-354.

BoüARD, Michel de, Guillaume le Conquérant, Paris, Presses universitaires de France, 1984 .

Bourassé, Jean-Jacques, Abbayes et monastères de France, histoire, monuments, souvenirs et ruines, Tours, A. Mame et fils, 1900.

Bourgain, Pascale, Les Muses et la louange: une poésie rouennaise du XI e siècle, sans doute de Garnier de Rouen, Marie-Françoise DAmogenot (adiuv.), in "Amicorum Societas". Mélanges offerts à François Dolbeau pour son $65^{e}$ anniversaire, Jacques Elfassi, Cécile Lanéry and Anne-Marie Turcan-Verkerk (eds), Firenze, SISMEL Edizioni del Galluzzo (Millennio Medievale, 96. Strumenti e Studi. Nuova Serie, 34), 2013, p. 101-118.

Boutémy, André, “Muriel. Note sur deux poèmes de Baudri de Bourgueil et de Serlon de Bayeux", Le Moyen Âge, 45, 1935, p. 241-251.

Boutémy, André, "Notice sur le recueil poétique du manuscrit Cotton Vitellius A XII, du British Museum", Latomus, 1, 1937, p. 278-313.

BоuтÉмy, André, “Deux poèmes inconnus de Serlon de Bayeux et une copie nouvelle de son poème contre les moines de Caen", Le Moyen Âge, 9, 1938, p. 241-269.

Boutémy, André, “À propos de Godefroid de Reims, Guillaume de Blois, Pierre la Rigge, Gautier Map, Nigellus de Longchamp, etc.", Revue du Moyen Âge latin, 1, 1945, p. 338-348.

BoutÉmy, André, “Autour de Godefroid de Reims”, Latomus, 6, 1947a, p. 231-255. 
BoutÉmy, André, “Trois œuvres inédites de Godefroi de Reims”, Revue du Moyen Âge latin, 3, 1947b, p. 335-366.

Boutémy, André, “Odon d'Orléans et les Origines de la Bibliothèque de Saint-Martin de Tournai”, in Mélanges dédiés à la Mémoire de Félix Grat, Émile-Aurèle VAN Mó́, Jeanne Vielliard and Pierre Marot (eds), vol. II, Paris, Pecqueur-Grat, 1949, p. 179-222.

Boutémy, André, “Essai de chronologie des poésies de Foulcoie de Beauvais", in Mélanges Henri Grégoire III = Annuaire de l'Institut de Philologie et d'Histoire Orientales et Slaves, 11, 1951, p. 79-96.

Brett, Martin, The English Church under Henry I, Oxford, Oxford University Press (Oxford Historical Monographs), 1975.

Broecker, Elmar, Gottfried von Reims, Kritische Gesamtausgabe. Mit einer Untersuchung zur Verfasserfrage und Edition der ihm zugeschriebenen Carmina, Frankfurt a.M., P. Lang, 2002.

BroeCKer, Elmar, Kritische Konkordanz zu den Gedichten Gottfried von Reims, Wien Berlin - Bruxelles - Frankfurt a.M. - Bern - New York - Oxford, P. Lang, 2003.

Brooks Nicholas P. and WALKer, Henry E., "The authority and interpretation of the Bayeux Tapestry", in Proceedings of the Battle Conference on Anglo-Norman Studies I 1978, Reginald Allen Brown (ed.), Woodbridge, Boydell Press, 1979, p. 1-34, 191-199.

Brouwer, Christian, "Les condamnations de Bérenger de Tours (XIe siècle)", in Problèmes d'histoire des religions, le penseur, la violence, la religion, Alain Dierkens (ed.), Bruxelles, Université de Bruxelles (Problèmes d'histoire des religions, 7), 1996, p. 9-23.

Brown, Reginald Allen, "William of Malmesbury as an architectural historian", in Mélanges d'archéologie et d'histoire médiévales en l'honneur du Doyen Michel de Boüard, Genève, Droz (Mémoires et documents de l'École des chartes, 27), 1982, p. 9-16.

Bultot, Robert, La doctrine du mépris du monde, en Occident, de S. Ambroise à Innocent III, IV. Le XI siècle 2. Jean de Fécamp, Hermann Contract, Roger de Caen, Anselme de Canterbury, Paris - Louvain, B. Nauwelaerts (Christianisme et valeurs humaines), 1964.

Burnett, Charles Stuart F., "The introduction of arabic learning into British schools”, in The Introduction of Arabic Philosophy into Europe, Charles E. Butterworth and Blake Andrée Kessel (eds), Leiden - New York - Köln, E.J. Brill (Studien und Texte zur Geistesgeschichte des Mittelalters, 39), 1994.

Burton, Janet E., "Gerard (d. 1108)", in Oxford Dictionary, 2004a, vol. XXI, p. 928-929.

Burton, Janet E., "Hugh the Chanter [Hugh the Chantor, Hugh Sottovagina] (d. c. 1140)", in Oxford Dictionary, 2004b, vol. XXVIII, p. 625-626.

Burton, Janet E., "Thomas (d. 1114)", in Oxford Dictionary, 2004c, vol. LIV, p. 270-272. Burton, Janet E., "Thurstan (c. 1070-1140)", in Oxford Dictionary, 2004d, vol. LIV, p. $723-724$.

C.A.L.M.A., Compendium Auctorum Latinorum Medii Aevi (50o-150o), Michael LAPIDGE, Silvia Nocentini and Francesco SANTI (eds), Firenze, SISMEL Edizioni del Galluzzo, 2000. 
Callahan, Thomas, "The making of a monster: The historical image of William Rufus”, Journal of Medieval History, 7, 1981, p. 175-185.

Cantin, André, "Ratio et auctoritas dans la première phase de la controverse eucharistique entre Bérenger et Lanfranc", Revue des études augustiniennes, 20, 1974, p. 155-186.

Capitani, Ovidio, Studi su Berengario di Tours, Lecce, Milella (Collezione di Studi e Testi, 2), 1966.

CAPITANi, Ovidio, "L'affaire bérengarienne ovvero dell'utilità delle monografie", Studi Medievali, 16, 1975, p. 353-378.

Carlos Villamarín, Helena de, "El poder de la poesía. Un tema de Godofredo de Reims", in Sub luce florentis calami. Homenaje a Manuel C. Díaz y Díaz, Manuela Domínguez García, Juan José Moralejo Álvarez, José Antonio Puentes Romay and Manuel Enrique Vázquez Buján (eds), Santiago de Compostela, Universidade de Santiago de Compostela, 2002, p. 289-303.

Carlos Villamarín, Helena de, "La materia de Troya en Godofredo de Reims", in Latin Culture in the Eleventh Century, 2002, vol. I, p. 186-213.

Carlos Villamarín, Helena de, "An approach to the meaning and value of the Epistolarum Liber of Godfrey of Rheims", Journal of Medieval Latin, 13, 2003a, p. 1-18.

Carlos Villamarín, Helena de, "On a new edition of the Carmina by Godfrey of Rheims: Gottfried von Reims, Kritische Gesamtausgabe”, Troianalexandrina, 3, 2003b, p. 9-22.

Catalano Tirrito, Michele, La venuta dei Normanni in Sicilia nella poesia e nella leggenda, Catania, Monaco e Mollica, 1903.

CHADwick, Henry, "Symbol and reality: Berengar and the appeal to the Fathers", in Auctoritas und Ratio, 1990, p. 25-45.

Chalandon, Ferdinand, Histoire de la domination normande en Italie et en Sicile, Paris, A. Picard, 1907, 2 vols.

Chaline, Jean-Pierre, L'Abbaye Saint-Ouen de Rouen des origines à nos jours, Rouen, Société de l'histoire de Normandie (Société de l'histoire de Normandie, 46), 2009.

Chandler, Victoria, “The last of the Montgomerys: Roger the Potevin and Arnulf”, Historical Research, 62, 1989, p. 1-14.

Chibnall, Marjorie, The World of Orderic Vitalis, Oxford, Clarendon Press, 1984.

Chibnall, Marjorie, Anglo-Norman England 1066-1166, Oxford, B. Blackwell, 1986.

Chibnall, Marjorie, “Anglo-French relations in the work of Ordericus Vitalis”, in Documenting the Past. Essays in Medieval History Presented to George Peddy Cuttino, Patricia J. Bradley and Jeffrey S. Hamilton (eds), Woodbridge - Wolfeboro, NH, Boydell Press, 1989, p. 5-19.

Chibnall, Marjorie, "A twelfth-century view of the historical church: Orderic Vitalis", in The Church Retrospective. Papers Read at the 1995 Summer Meeting and the 1996 Winter Meeting of the Ecclesiastical History Society. In Memory of Andrew Martindale, Robert Norman Swanson (ed.), Woodbridge - Rochester, NY, Boydell Press for the Ecclesiastical History Society (Studies in Church History, 33), 1997, p. 115-134.

Chitr, Elisa, "Gilbertus Crispinus”, in C.A.L.M.A., vol. IV/3, 2013, p. 348-350. 
Cizek, Alexandru Nicolae, "Das Bild von der docta femina in mittellateinischen Dichtungen an der Schwelle des Hochmittelalters", in Poesía latina medieval (siglos $V-X V$ ). Actas del IV Congreso del "Internationales Mittellateinerkomitee" (Santiago de Compostela, 12-15 septiembre de 2002), Manuel Cecilio Díaz y Díaz and José Manuel Díaz de Bustamante (eds), Firenze, SISMEL Edizioni del Galluzzo (Millennio Medievale, 55. Atti di Convegni, 17), 2005, p. 471-481.

Clay, Charles T., "The early precentors and chancellors of York”, Yorkshire Archaeological Journal, 35, 1941, p. 116-138.

Clay, Charles T., "Notes on the early archdeacons in the church of York", Yorkshire Archaeological Journal, 36, 1946, p. 269-287, 409-434.

Cochrane, Louise, Adelard of Bath: The First English Scientist, London, British Museum Press, 1994.

Cokayne, George Edward P., The Complete Peerage of England, Scotland, Ireland, Great Britain and the United Kingdom, vol. XI, London, The St. Catherine Press, 1949.

Colker, Marvin L., "Fulcoii Belvacensis Epistulae", Traditio, 10, 1954, p. 191-273.

Colker, Marvin L., "Fulcoius of Beauvais, poet and propagandist", in Latin Culture in the Eleventh Century, 2002, vol. I, p. 144-157.

Contini, Federico, "Durandus Troarnensis abbas", in C.A.L.M.A., vol. III/2, 2009, p. 165.

Corbin, Michel, Prière et raison de la foi. Introduction à l'œuvre de S. Anselme de Cantorbéry, Paris, Cerf (L'œuvre d'Anselme de Cantorbéry), 1992.

Cottineau Laurent H., Répertoire topo-bibliographique des Abbayes et Prieurés, Mâcon, Protat frères, 1935-1937, 2 vols.

Cowdrey, Herbert Edward John, "Archbishop Thomas and the Pallium”, Haskins Society Journal, 11, 1998, p. 31-41.

Cowdrey, Herbert Edward John, Lanfranc. Scholar, Monk and Archbishop, Oxford, Oxford University Press, 2003.

Cowdrey, Herbert Edward John, "Thomas (d. 1100)", in Oxford Dictionary, 2004, vol. LIV, p. 268-270.

Cristiani, Marta, "Le 'ragioni' di Berengario di Tours", in Lanfranco di Pavia e l'Europa, 1993, p. 327-36o.

Crouch, David, The Normans: The History of a Dynasty, London - New York, Hambledon and London, 2002.

D’Angelo, Edoardo, Il latino dei Normanni. Temi e linguaggi storiografici, Napoli, L'Orientale (Mezzogiorno e Mediterraneo, 1), 2003 a.

D’Angelo, Edoardo, “Morfologie della narrazione storiografica nel Mezzogiorno normanno-svevo ed angioino", in D’Angelo, Storiografi e cronologi latini del Mezzogiorno normanno-svevo, Napoli, Liguori (Biblioteca. Nuovo Medioevo, 69), 2003 b, p. 3-62.

D'ANGELo, Edoardo, "Modèles classiques de l'hexamètre historiographique normand", in L'historiographie médiévale normande et ses sources antiques, $X^{e}$-XII ${ }^{e}$ siècle, Actes du colloque de Cerisy-la-Salle et du Scriptorial d'Avranches (6-11 octobre 2009), Pierre Bauduin and Marie-Agnès Lucas-Avenel (eds), Caen, Presses universitaires de Caen, 2014, p. 307-326. 
D'Onofrio, Giulio, "La crisi dell'equilibrio teologico altomedievale (1030-1095)", in Storia della teologia nel medioevo I I principi, Giulio D’Onofrio (ed.), Casale Monferrato (Alessandria), Piemme, 1996.

Dalarun, Jacques, "Marbod of Rennes (c. 1035-1123)", in Encyclopedia of the Middle Ages, André Vauchez (ed.), Barrie Dobson - Michael Lapidge (adiuv.), vol. II, Cambridge - Paris - Roma, J. Clarke - Cerf - Città Nuova, 2000, p. 902-903.

Dales, Douglas, Dunstan. Saint and Statesman, Cambridge, Lutterworth Press, 1988.

DAvid, Charles Wendell, Robert Curthose, Duke of Normandy, Cambridge, MA, Harvard University Press (Harvard Historical Studies, 25), 1920.

DAvis, Henry William Carless, "Henry of Blois and Brian Fitz-Count", English Historical Review, 25, 1910, p. 297-303.

Davis, Ralph Henry Carless, “The Carmen de Hastingae Proelio", English Historical Review, 92, 1978, p. 241-261.

DAvis, Ralph Henry Carless and Engels, Lodewijk Jozef, "The Carmen de Hastingae Proelio: A discussion", in Anglo-Norman Studies II Proceedings of the Battle Conference 1979, Reginald Allen Brown (ed.), Woodbridge, Boydell Press, 1979, p. 1-20, 165-167.

De Marco, Maria, Epos e ritmi dell'età comunale, Bari, Adriatica, 1983.

Degl'Innocenti, Antonella, L'opera agiografica di Marbodo di Rennes, Spoleto, Centro Italiano di Studi sull'Alto Medioevo (Biblioteca di Medioevo latino, 3), 1990.

Delisle, Léopold, "Vers et écriture d'Orderic Vital”, Journal des savants, 1, 1903, 429-440.

Devailly, Guy, "Un évêque et un prédicateur errant au XII ${ }^{\mathrm{e}}$ siècle: Marbode de Rennes et Robert d'Arbrissel”, Mémoires de la Société d'Histoire et d'Archéologie de Bretagne, 57, 1980, p. 163-170.

Dieudonné, Adolphe, Hildebert de Lavardin, évêque du Mans, archevêque de Tours (1056-1133). Sa vie, ses lettres, Paris, A. Picard, 1898.

Dolbeau, François, "Prose, rythme et mètre: réécritures dans le dossier de saint Ouen”, in La réécriture hagiographique dans l'Occident médiéval. Transformations formelles et idéologiques, Monique Goullet and Martin Heinzelmann (eds), Ostfildern, J. Thorbecke (Beihefte der Francia, 58), 2003, p. 231-250.

Dolbeau, François, "Deux poèmes inédits, extraits du Livre noir de Saint-Ouen de Rouen", in Sanctorum societas. Récits latins de sainteté (III ${ }^{e}-X I I^{e}$ siècles), vol. II, Bruxelles, Société des Bollandistes (Subsidia hagiographica, 85), 2005, p. 747-80o.

Dosdat, Monique, "Les Évêques de la province de Rouen et la vie intellectuelle au $\mathrm{XI}^{\mathrm{e}}$ siècle", in Les évêques normands du XIe siècle. Colloque de Cerisy-la-Salle, 30 septembre-3 octobre 1993, Pierre Bouet and François Neveux (eds), Caen, Presses Universitaires de Caen, 1995, p. 223-252.

Douglas, David C., "Rollo of Normandy", English Historical Review, 57, 1942, p. 414436.

Douglas, David C., “The earliest Norman counts”, English Historical Review, 61, 1946, p. 129-156.

Douglas, David C., William the Conqueror. The Norman Impact upon England, London, Eyre and Spottiswoode, 1964. 
Drew, Alison, "The De eodem et diverso", in Adelard of Bath. An English Scientist and Arabist in the Early Twelfth Century, Charles Stuart F. Burnetr (ed.), London, Warburg Institute, University of London (Warburg Institute Surveys and Texts, 14), 1987, p. 17-24.

Dronke, Peter, Medieval Latin and the Rise of European Love-Lyric I Problems and Interpretations, Oxford, Clarendon Press, 1965.

Dronke, Peter, Women Writers in the Middle Ages. A Critical Study of Texts from Perpetua to Marguerite Porete, Cambridge, Cambridge University Press, 1984.

Dronke, Peter, Poetic Individuality in the Middle Ages. New Departures in Poetry 10oo1150, London, Westfield College, University of London Committee for Medieval Studies (Westfield publications in medieval studies, 1), 1986.

Dufour, Jean, "Le rouleau des morts de saint Bruno", in Comptes rendus des séances de l'Académie des Inscriptions et Belles-Lettres de l'année 2003, janvier-mars, Paris, Académie des Inscriptions et Belles-Lettres, 2003, p. 5-26.

Dumville, David Norman, "Images of the Viking in eleventh-century Latin literature", in Latin Culture in the Eleventh Century, 2002, vol. I, p. 250-263.

Emons-Nijenhuis, Wiesje F., "The embedded saint, the Wilton Chronicle's Life of St. Wulfthryth", Revue bénédictine, 119, 2009, p. 86-210.

EngeLs, Lodewijk Jozef, Dichters over Willem de Veroveraar: het "Carmen de Hastingae Proelio", Groningen, J.B. Wolters, 1967.

Ernault, Léon, Marbode, évêque de Rennes, sa vie et ses ceuvres (1035-1123), Émile Ernault and Félix Robiou (praef.), Rennes, H. Caillière, 1889.

Evans, Gillian Rosemary, "Gilbert Crispin, abbot of Westminster: The forming of a monastic scholar", Studia Monastica, 22, 1980a, p. 63-81.

Evans, Gillian Rosemary, "Gilbert Crispin on the eucharist: A monastic postscript to Lanfranc and Berengar”, Journal of Theological Studies, 31, 198ob, p. 28-43.

Evans, Gillian Rosemary, “Omnibus hiis litteratior: Gilbert Crispin noted theologian”, Studi Medievali, 22, 1981, p. 695-716.

Everett Green, Mary Anne, Lives of the Princesses of England from the Norman Conquest, vol. I, London, H. Colburn, 1849.

FARMER, David Hugh, “William of Malmesbury's life and works”, Journal of Ecclesiastical History, 13, 1962, p. 39-54.

FERRANTE, Joan M., To the glory of her sex: women's roles in the composition of medieval texts, Bloomington, IN, Indiana University Press, 1997.

Ferrante, Joan M., Epistolae. Medieval Women's Latin Letters, https://epistolae.ctl. columbia.edu/home, accessed 2 July 2018

FErrari, Michele Camillo, "Das letzte Jahrhundert. Lateinische Literatur im 11. Jahrhundert”, in Canossa 1077 - Erschütterung der Welt. Geschichte, Kunst und Kultur am Aufgang der Romanik I Essays II Katalog, Christoph Stiegemann and Matthias Wemhoff (eds), vol. I, München, Hirmer, 2006, p. 573-578.

Fleming Robin, "Monastic lands and England's defence in the Viking age", English Historical Review, 100, 1985, p. 247-265.

Fleming, Robin, Kings and Lords in Conquest England, Cambridge, Cambridge University Press (Cambridge Studies in Medieval Life and Thought. Fourth Series, 15) 1991. 
Freeman, Edward Augustus, The Reign of William Rufus and the Accession of Henry the First, Oxford, Clarendon Press, 1882, 2 vols.

Fröhlich, Walter, "Die bischöflichen Kollegen des hl. Erzbischofs Anselm von Canterbury I 1093-1097 II 1100-1109”, Analecta Anselmiana, 2, 1970, p. 117-168.

FuiAno, Michele, "Una fonte dei Gesta Roberti Wiscardi di Guglielmo di Puglia, la presunta opera di Giovanni Arcidiacono", Convivium, 2, 1950, p. 249-270.

FuiAno, Michele, "Guglielmo di Puglia, storico di Roberto il 'Guiscardo", Archivio storico per le Provincie napoletane, 71, 1950-1951, p. 17-43.

Fuiano Michele, "Guglielmo di Puglia”, in Michele Fuiano, Studi di storiografia medioevale, Napoli, Giannini (Storia e Pensiero, 7), 1960, p. 13-102.

Galbraith, Vivian Hunter, "Gerard the Chancellor", English Historical Review, 46, 1931, p. 77-79.

Galloway, Andrew, "Word-play and political satire: Solving the riddle of the text of Jezebel", Medium Aevum, 68, 1999, p. 189-208.

GAmberini, Roberto, "Berengarius Turonensis", in C.A.L.M.A., vol. II/2, 2005, p. 261265.

Gazeau, Véronique, "Normannia monastica”. Prosopographie des abbés bénédictins ( $X^{e}$-XII siècle), Caen, Publications du CRAHM, 2007, 2 vols.

Gerhard, Hartwig, Der "Liber proverbiorum" des Godefrid von Winchester, Würzburg, s.n., 1974 .

GHellinck, Joseph de, Littérature latine au Moyen Âge. Depuis les origines jusqu'à la fin de la Renaissance carolingienne, Paris, Bloud and Gay, 1939, 2 vols.

Gibson, Margaret Templeton, Lanfranc of Bec, Oxford, Clarendon Press, 1978.

Gibson, Margaret Templeton, "Letters and charters relating to Berengar of Tours", in Auctoritas und Ratio, 1990, p. 5-23.

Gillingham, John, "Henry of Huntingdon and the XIIth-century revival of the English nation", in Concepts of National Identity in the Middle Ages, Simon N. Forde, Lesley Johnson and Alan V. Murray (eds), Leeds, Leeds Studies in English, University of Leeds (Leeds Texts and Monographs. New Series, 14), 1995, p. 75-101.

GosLIng, John, "The identity of lady Aelfgyla in the Bayeux Tapestry and some speculation regarding the hagiographer Goscelin”, Analecta Bollandiana, 108, 1990, p. 71-79.

Goulburn, Edward Meyrick and Symonds, Henry, The Life, Letters and Sermons of Bishop Herbert de Losinga (b. circ. A.D. 1050, d. 1119), Oxford - London, J. Parker, 1878, 2 vols.

Goullet, Monique, "Poésie et mémoire des morts. Le rouleau funèbre de Mathilde, abbesse de la Sainte-Trinité de Caen ( $\dagger 1113)$ ”, in “Ad libros”. Mélanges offerts à Denise Angers et Joseph-Claude Poulin, Jean-François Cottier, Véronique Gazeau, Martin Gravel and Sébastien Rossignol (eds), Montréal, Presses de l'Université de Montréal, 2010, p. 163-198.

Goullet, Monique, "De Normandie en Angleterre: enquête sur la poétique de trois rouleaux mortuaires", Tabularia [On line], Autour de Serlon de Bayeux: la poésie normande aux $X I^{e}$-XII ${ }^{e}$ siècles. On line: 20 october 2016. URL: http://journals. openedition.org/tabularia/2782. 
Gransden, Antonia, Historical Writing in England I c. 550-c. 1307, London, Routledge, 1997.

Grassi, John, "The Vita Aedwardi Regis. The hagiographer as insider", in AngloNorman Studies XXVI Proceedings of the Battle Conference 2003, John Gillingham (ed.), Woodbridge, Boydell Press, 2004, p. 87-102.

Green, Judith, "William Rufus, Henry I and the Royal Demesne”, History, 64, 1979, p. 337-352.

Green, Judith, The Government of England under Henry I, Cambridge, Cambridge University Press (Cambridge Studies in Medieval Life and Thought. Fourth Series, 3), 1986.

Green, Judith, "Le Gouvernement d'Henri I ${ }^{\text {er }}$ Beauclerc en Normandie", in La Normandie et l'Angleterre au Moyen Âge, Pierre Bouet and Véronique Gazeau (eds), Caen, Publications du CRAHM, 2003, p. 61-73.

Green, Judith, Henry I: King of England and Duke of Normandy, Cambridge, Cambridge University Press, 2006.

Greenway, Diana E., "Henry of Huntingdon and Bede", in L'historiographie médiévale en Europe. Actes du colloque organisé par la Fondation Européenne de la Science au Centre de Recherches Historiques et Juridiques de l'Université Paris I du 29 mars au $1^{\text {er }}$ avril 1989, Jean-Philippe GenÊt (ed.), Paris, Éditions du Centre National de la Recherche Scientifique, 1991, p. 43-50.

Greenway, Diana E., “Authority, convention and observation in Henry of Huntingdon's Historia Anglorum", in Anglo-Norman Studies XVIII Proceedings of the Battle Conference 1995, Christopher HARPER-BILl (ed.), Woodbridge, Boydell Press, 1996, p. 105-121.

Greenway, Diana E., "Henry [Henry of Huntingdon] (c. 1088-c. 1157)", in Oxford Dictionary, 2004, vol. XXVI, p. 413-415.

Greenway, Diana E., "Henry of Huntingdon as Poet: The De herbis Rediscovered", Medium aevum, 74, 2005, p. 329-332.

GrÉGoIre, Réginald, "Marbode", in Dictionnaire de Spiritualité, Ascétique et Mystique, Doctrine et Histoire, vol. X, Paris, Beauchesne, 1977, p. 241-244.

Grierson, Philip, "The Relations between England and Flanders before the Norman Conquest”, Transactions of the Royal Historical Society, Fourth Series, 23, 1941, p. 71-112.

Grinnell-Milne, Duncan, The Killing of William Rufus. An Investigation in the New Forest, Newton Abbot - New York, David and Charles - A.M. Kelley, 1968.

Gullick, Michael, “The scribal work of Eadmer of Canterbury to 1109”, Archaeologia Cantiana, 118, 1998, p. 173-189.

HALL, John Barrie, "Critical notes on three medieval latin texts: Vita Gundulfi, Carmen de Hastingae Proelio, Vita Merlini”, Studi Medievali, 21, 1980, p. 899-916.

Hamilton, Thomas J., Goscelin of Canterbury: A Critical Study of His Life, Works and Accomplishments, $\mathrm{PhD}$ Thesis, University of Virginia, 1973.

Hardy, Thomas Duffus, Descriptive Catalogue of Materials Relating to the History of Great Britain and Ireland to the End of the Reign of Henry VII, vol. II, London, Longman (Rerum Britannicarum Medii Aevi Scriptores, or Chronicles and Memorials of Great Britain and Ireland during the Middle Ages, 26-2), 1865. 
Harper-Bill, Christopher, "Losinga, Herbert de (d. in 1119)", in Oxford Dictionary, 2004, vol. XXXIV, p. 467-470.

HAskins, Charles Homer, Studies in the History of Mediaeval Science, Cambridge, MA, Harvard University Press, 1924.

HauréAu, Barthélemy, Mélanges poétiques d'Hildebert de Lavardin, Paris, G. PedoneLauriel, 1882.

HauréAu, Barthélemy, Notices et extraits de quelques manuscrits latins de la Bibliothèque nationale, vol. I, Paris, C. Klincksieck, 1890.

Haye, Thomas, Christliche und pagane Dichtung bei Fulcoius von Beauvais, in Latin Culture in the Eleventh Century, 2002, vol. I, p. 398-409.

Hayward, Paul Antony, Translation-Narratives in Post-Conquest Hagiography and English Resistance to the Norman Conquest, in Anglo-Norman Studies XXI Proceedings of the Battle Conference 1998, Christopher HARPER-Bill (ed.), Woodbridge, Boydell Press, 1999, p. 67-93.

HAYWARD, Rebecca and BARNES, William Reginald, Goscelin's Liber Confortatorius, in Writing the Wilton Women, 2004, p. 99-207.

Hermans, Jos Maria Martinus and Van Houts, Elisabeth Maria Cornelia, “The History of a membrum disiectum of the Gesta Normannorum Ducum, Now Vatican, Reg. Lat. 733, fol. 51", Mededelingen van het Nederlands Instituut te Rome, 9-10, 1983, p. 79-94, 219-26.

Herrmann, Léon, "Une vie inédite de saint Gommaire”, Latomus, 3, 1939, p. 164-182.

Herrmann, Léon, “Thiébaut de Vernon”, Le Moyen Âge, 11, 1940, p. 30-43.

Heurtevent, Raoul, Durand de Troarn et les origines de l'hérésie bérengarienne, Paris, G. Beauchesne et Cie (Études de théologie historique, 5), 1912.

Hilbert, Karlheinz, Studien zu den "Carmina" des Baudri von Bourgueil, PhD Thesis, University of Heidelberg, 1967.

Hingst, Amanda Jane, The Written World. Past and Place in the Work of Orderic Vitalis, Notre Dame, IN, University of Notre Dame Press, 2009.

Hirsch, Ferdinand Ludwig Richard, De Italiae inferioris annalibus saeculi decimi et undecimi, Berlin, G. Lange, 1864.

Hirsch, John Campion, "Church and monarchy in the Carmen de Hastingae proelio", Journal of Medieval History, 8, 1982, p. 353-357.

Hoffmann, Hartmut, "Die Anfänge der Normannen in Süditalien”, Quellen und Forschungen aus italienischen Archiven und Bibliotheken, 49, 1969, p. 95-144.

Holdsworth, Christopher J., "Orderic, traditional monk and the new monasticism", in Tradition and Change. Essays in Honour of Marjorie Chibnall Presented by Her Friends on the Occasion of Her Seventieth Birthday, Diana E. Greenway, Christopher J. Holdsworth, Jane E. Sayers (eds), Cambridge, Cambridge University Press, 1985, p. 21-34.

Hollis, Stephanie, Goscelin's Writings and the Wilton Women, in Writing the Wilton Women, 2004, p. 217-244.

Hollis, Stephanie, "Strategies of emplacement and displacement. St Edith and the Wilton community in Goscelin's legend of Edith and Liber confortatorius", in A Place to Believe In. Locating Medieval Landscapes, Clare A. Lees and Gillian R. Overing (eds), University Park, PA, Pennsylvania State University Press, 2006, p. 150-169. 
Hollister, C. Warren, “The strange death of William Rufus”, Speculum, 48, 1973, p. $637-653$.

Hollister, C. Warren, “Henry I (1068/9-1135)", in Oxford Dictionary, 2004, vol. XXVI, p. 421-434

Holopainen, Toivo J., "Augustine, Berengar and Anselm on the role of reason in theology", in Was ist Philosophie im Mittelalter? Akten des X. Internationalen Kongresses für mittelalterliche Philosophie der Société Internationale pour l'Etude de la Philosophie Médiévale, 25. bis 30. August 1997 in Erfurt, Jan A. Aertsen and Andreas Speer (eds), Berlin - New York, W. de Gruyter (Miscellanea mediaevalia, 26), 1998, p. 553-559.

Huneycutt, Lois L., "Proclaiming her Dignity abroad: the literary and artistic network of Matilda of Scotland, Queen of England, 1100-1118", in The Cultural Patronage of Medieval Women, June Hall Martin McCash (ed.), Athens, GA, The University of Georgia Press, 1996, p. 155-174.

Huneycutr, Lois L., Matilda of Scotland: A Study in Medieval Queenship, Woodbridge, Boydell Press, 2003.

Huneycutt, Lois L., “Adela, Countess of Blois (c. 1067-1137)”, in Oxford Dictionary, 2004a, vol. I, p. 336-337.

Huneycutt, Lois L., "Matilda [Edith, Mold, Matilda of Scotland] (1080-1118)", in Oxford Dictionary, 2004b, vol. XXXVII, p. 320-321.

Hunt, Richard William, Saint Dunstan's classbook from Glastonbury: Codex Biblioth. Bodleianae Oxon. Auct. F. 4./32, Amsterdam, North-Holland Publishing Company (Umbrae Codicum Occidentalium, 4), 1961.

JÄschкe, Kurt-Ulrich, Wilhelm der Eroberer. Sein doppelter Herrschaftsantritt im Jahre 1066, Sigmaringen, J. Thorbecke (Vortrage und Forschungen. Sonderband, 24), 1977.

JAEger, C. Stephen, The Envy of Angels. Cathedral Schools and Social Ideals in Medieval Europe, 950-120o, Philadelphia, PA, University of Pennsylvania Press (Middle Ages Series), 1994.

Jolivet, Jean, “Adélard de Bath et l'amour des choses”, in Métaphysique. Histoire de la philosophie. Recueil d'études offert à Fernand Brunner, Neuchâtel, A la Baconnière (Langages, 85), 1981, p. 77-84.

Jones, Gwyn, A History of the Vikings, Oxford, Oxford University Press, 1968.

Karkov, Catherine E., "Pictured in the heart: The Ediths at Wilton", in Intertexts. Studies in Anglo-Saxon Culture Presented to Paul E. Szarmach, Virginia Blanton and Helene E. Sснеск (eds), Tempe, AZ - Turnhout, Arizona Center for Medieval and Renaissance Studies - Brepols (Arizona Studies in the Middle Ages and the Renaissance, 24 - Medieval and Renaissance Texts and Studies, 334), 2008, p. 273-288.

Keefe, Thomas K., "Henry II (1133-1189)", in Oxford Dictionary, 2004, vol. XXVI, p. 434-449.

Keynes, Simon and Love, Rosalind C., "Earl Godwine's Ship”, Anglo-Saxon England, 38,2009, p. $185-223$.

Killings, Steve, "Reginald's Verses on the Canterbury Shrines", in Revue bénédictine, 120, 2010, p. 81-88. 
KING, Edmund, "Blois, Henry de (c. 1096-1171)", in Oxford Dictionary, 2004, vol. VI, p. $238-242$.

KNowles, David, The Monastic Order in England. A History of Its Development from the Times of St Dunstan to the Fourth Lateran Council 943-1216, Cambridge, Cambridge University Press, 1949, p. 31-19o.

Koopmans, Rachel M., Wonderful to Relate. Miracle Stories and Miracle Collecting in High Medieval England, Philadelphia, PA, University of Pennsylvania Press (The Middle Ages Series), 2011.

Lack, Katherine, Conqueror's Son: Duke Robert Curthose, Thwarted King, Stroud, Sutton, 2007.

Landgraf, Artur Michael, "Probleme des Schrifttums Brunos des Kartäusers”, Collectanea Franciscana, 8, 1940, p. 542-590.

Lanfranco di Pavia e l'Europa del secolo XI. Nel IX centenario della morte (1089-1989). Atti del Convegno internazionale di studi (Pavia, Almo Collegio Borromeo, 21-24 settembre 1989), Giulio D’Onofrio (ed.), Roma, Herder (Italia sacra: studi e documenti di storia ecclesiastica, 51), 1993.

LANZA, Lidia, “Adelardus Bathoniensis”, in C.A.L.M.A., vol. I/1, 200o, p. 37-40.

LAPIDGE, Michael, “Three latin poems from Aethelwold's school at Winchester", Anglo-Saxon England, 1, 1972, p. 85-137.

LAPIDGE, Michael, "Ealdred of York and MS. Cotton Vitellius E. XII”, The Yorkshire Archaeological Journal, 55, 1983, p. 11-25 [reimpr. in LAPIDGE, Anglo-Latin Literature 900-1066, London-Rio Grande, OH, Hambledon Press, 1993, p. 453-467].

LAPIDGe, Michael, “The lost Passio Metrica S. Dionysii by Hilduin of Saint-Denis”, Mittellateinisches Jahrbuch, 22, 1987, p. 56-79.

LAPIDGE, Michael, "Artistic and literary patronage in Anglo-Saxon England”, in Committenti e produzione artistico-letteraria nell'alto medioevo occidentale: XXXIX settimana di studio del Centro Italiano di Studi sull'Alto Medioevo, Spoleto, 4-10 aprile 1991, vol. I, Spoleto (Perugia), Centro Italiano di Studi sull'Alto Medioevo, 1992, p. 137-191.

LAPIDGE, Michael, "Some remnants of Bede's lost Liber Epigrammatum", in Michael LAPIDGE, Anglo-Latin Literature 600-899, London - Rio Grande, OH, Hambledon Press, 1996, p. 357-379.

LAPIDGE, Michael, "Dunstan [St Dunstan] (d. 988), Archbishop of Canterbury", in Oxford Dictionary, 2004, vol. XVII, p. 347-353.

LAPIDGE, Michael, "Eadmerus Cantuariensis monachus”, in C.A.L.M.A., vol. III/2, 2009a, p. 165-166.

LAPIDGe, Michael, "Eduardus Anglorum rex dictus Confessor", in C.A.L.M.A., vol. III/2, 2009b, p. 185-186.

LAPIDGE, Michael, “Gaufridus Wintoniensis”, in C.A.L.M.A., vol. IV/2, 2012, p. 135.

LAPIDGE, Michael, "Gerhardus Eboracensis archiepiscopus”, in C.A.L.M.A., vol. IV/3, 2013, p. 260-261.

LAPIDGE, Michael, "Guido Ambianensis episcopus”, in C.A.L.M.A., vol. IV/5, 2014a, p. 512.

LAPIDGE, Michael, “Guillelmus I Anglorum rex”, in C.A.L.M.A., vol. IV/5, 2014b, p. 588. 
LAPIDGE, Michael and Love, Rosalind C., "The Latin hagiography of England and Wales (600-1550)", in Hagiographies. Histoire internationale de la littérature hagiographique latine et vernaculaire en Occident des origines à 1550, Guy PHILIPPART (ed.), vol. III, Turnhout, Brepols, 2001, p. 203-325.

LAPIdge, Michael and Love, Rosalind C., "Dunstanus Cantuariensis archiepiscopus”, in C.A.L.M.A., vol. III/2, 2009, p. 156.

Latin Culture in the Eleventh Century. Proceedings of the Third International Conference on Medieval Latin Studies. Cambridge, September 9-12 1998, Michael W. Herren, Christopher James McDonough and Ross G. Arthur (eds), Turnhout, Brepols (Publications of the Journal of Medieval Latin, 5), 2002, 2 vols.

Latzke, Therese, "Der Fürstinnenpreis”, Mittellateinisches Jahrbuch, 14, 1979, p. 22-65.

Lauletta, Mario, “Allusioni intertestuali nel prologus dei Gesta Roberti Wiscardi di Guglielmo il Pugliese”, AION. Annali dell'Università degli Studi di Napoli "L'Orientale", 35, 2003, p. 179-183.

Leblond, Bernard, L'Accession des Normands de Neustrie à la culture occidentale ( $X^{e}-X I^{e}$ Siècles), Paris, A.G. Nizet, 1966.

LeClerCQ, Jean, “Une doctrine de la vie monastique dans l'école du Bec”, in Spicilegium Beccense. Congrès international du IXe centenaire de l'arrivée d'Anselme au Bec, Le Bec-Hellouin - Paris, Abbaye Notre-Dame du Bec (Eure) - J. Vrin (Études de philosophie médiévale), 1959, p. 477-488.

Lecomte, Maurice, Foulcoie de Beauvais, archidiacre de Meaux (XI siècle): éloge de Meaux, vies de saint Faron et saint Blandin, épitaphes, Provins, H. Paré, 1897.

Lectures médiévales de Virgile. Actes du colloque organisé par l'École Française de Rome (Rome, 25-28 octobre 1982), Jean-Yves Tilliette (praef.), Roma, École Française de Rome (Collection de l'École française de Rome, 80), 1985.

Lenzen, Rolf, "Sodomitenschelte. Eine Invektive des Serlo von Bayeux?", in Arbor amoena comis 25. Jahre Mittellateinisches Seminar in Bonn 1965-199o, Ewald KöNSGEN (ed.), Dieter Schaller (praef.), Stuttgart, F. Steiner, 1990, p. 189-192.

Leotta, Rosario, "L’esametro di Guglielmo il Pugliese”, Giornale italiano di filologia, 7, 1976, p. 292-299.

Lettinck, Nico, "Comment les historiens de la première moitié du XII ${ }^{\mathrm{e}}$ siècle jugeaientils leur temps?”, Journal des savants, 1984 (but 1987), p. 51-77.

LEwIS, Christopher P., "The early earls of Norman England”, in Anglo-Norman Studies XIII Proceedings of the Battle Conference 199o, Marjorie ChiBnall (ed.), Woodbridge, Boydell Press, 1991, p. 207-223.

Leyser, Henrietta, “c. 1080-1215: Texts", in The Cambridge Companion to Medieval English Mysticism, Samuel Fanous and Vincent Gillespie (eds), Cambridge, Cambridge University Press (Cambridge Companions to Literature), 2011, p. 49-67.

Licence, Tom, Hermits and Recluses in English Society, 950-120o, Oxford, Oxford University Press, 2011.

Liebermann, Felix, "Raginald von Canterbury", Neues Archiv, 13, 1888, p. 519-556.

Lind, Levi Robert, The "Vita Sancti Malchi” of Reginald of Canterbury, Urbana, IL, University of Illinois Press (University of Illinois Studies in Language and Literature, 27, 3-4), 1942. 
Lo Prete, Kimberly A., “The Anglo-Norman card of Adela of Blois”, Albion, 22, 1990, p. 569-589.

Lo Prete, Kimberly A., "Adela of Blois and Ivo of Chartres: Piety, politics and the peace in the diocese of Chartres", in Anglo-Norman Studies XIV Proceedings of the Battle Conference 1991, Marjorie Chibnall (ed.), Woodbridge, Boydell Press, 1992a, p. 131-152.

Lo Prete, Kimberly A., A Female Ruler in Feudal Society: Adela of Blois (c. 1067-c. 1137), PhD Thesis, University of Chicago, IL, 1992b, 2 vols.

Lo Prete, Kimberly A., "Adela of Blois as mother and countess", in Medieval Mothering, John Carmi Parsons and Bonnie Wheeler (eds), New York - London, Garland (The New Middle Ages, 3), 1996, p. 313-336.

Lo Prete, Kimberly A., Adela of Blois: Countess and Lord (c. 1067-1137), Dublin, Four Courts Press, 2007.

Love, Rosalind C., “Anselmus Cantuariensis archiep.”, in C.A.L.M.A., vol. I/3, 2001, p. 288-291.

Love, Rosalind C., "Goscelinus Sancti Bertini monachus”, in C.A.L.M.A., vol. IV/4, 2013, p. 393-398.

Lucas-Avenel, Marie-Agnès and D’Angelo, Edoardo, "Vers une nouvelle édition des poèmes de Serlon de Bayeux", Tabularia [On line], Autour de Serlon de Bayeux: la poésie normande aux XI ${ }^{e}$-XII ${ }^{e}$ siècles. On line: 24 october 2017. URL: http://journals. openedition.org/tabularia/2897.

Luff, G.A., "Norman sense and sensibility. Abbot Gilbert Crispin ad Westminster", The Dublin Review, 235, 1961, p. 374-384.

MAAZ, Wolfgang, "Epigrammatisches Sprechen im Lateinischen Mittelalter", in Mittelalterliche Komponenten des europäischen Bewußtseins. Mittelalterliches Colloquium im Wissenschaftskolleg zu Berlin am 27. Januar 1983, Josef SzövÉRFFY and Fritz Wagner (eds), Berlin, Classical Folia (Medieval Classics. Texts and Studies, 17), 1983, p. 101-129.

MaAz, Wolfgang, "Dekonstruierte Freundschaft. Zur Rezeption von Martial II 24, II 43, III 26 und III 46 bei Godefrid von Winchester", in "Mentis amore ligati". Lateinische Freundschaftsdichtung und Dichterfreundschaft in Mittelalter und Neuzeit. Festgabe für Reinhard Düchting zum 65. Geburtstag, Boris KörKEL, Tino Licht and Jolanta Wiendlocha (eds), Heidelberg, Mattes, 2001, p. 293-303.

MacDonald, Allan John, Berengar and the Reform of Sacramental Doctrine, London, Longmans, 1930.

MACY, Gary, "Berengar's legacy as heresiarch", in Auctoritas und Ratio, 1990, p. 47-67.

Mason, Emma, "William Rufus: myth and reality", Journal of Medieval History, 3 , 1977, p. 1-20.

Mason, Emma, "William Rufus and the historians", Medieval History, 1, 1991, p. 6-22.

Mason, Emma, King Rufus: The Life and Murder of William II of England, Stroud, History, 2008.

Mason, John Frederick A., "Roger de Montgomery and his sons (1067-1102)", Transactions of the Royal Historical Society, Fifth Series, 13, 1963, p. 1-28. 
Mason, John Frederick A., "Belmeis, Richard de (d. 1127)", in Oxford Dictionary, 2004a, vol. V, p. 34-35.

Mason, John Frederick A., "Montgomery, Roger de, first earl of Shrewsbury (d. 1094)", in Oxford Dictionary, 2004b, vol. XXXVIII, p. 866-870.

Masson, André, Lafond, Jean and Battre, William James, L'église abbatiale SaintOuen de Rouen, Paris, H. Laurens (Petites monographies des grands édifices de la France), 1927.

Mathieu, Marguerite, "Une source négligée de la bataille de Mantzikert, les Gesta Roberti Wiscardi", Byzantion, 20, 1950, p. 89-103.

Mathieu, Marguerite, "Le manuscrit 162 d'Avranches et l'édition princeps des Gesta Roberti Wiscardi de Guillaume d'Apulie", Byzantion, 24, 1954, p. 11-130.

Maurach, Gregor, “Adelhard von Bath - ein Naturdenker des 12. Jahrhunderts", Abhandlungen der Braunschweigischen wissenschaftlichen Gesellschaft, 34, 1982, p. 173-197.

McDonough, Christopher James, "Warner of Rouen and the monk from Mont SaintMichel”, Mittellateinisches Jahrbuch, 32/2, 1997, p. 23-51.

McDonough, Christopher James, "Classical latin satire and the poets of northern France: Baudri of Bourgueil, Serlo of Bayeux, and Warner of Rouen”, in Latin Culture in the Eleventh Century, 2002, vol. II, p. 102-115.

McDonough, Christopher James, "Warner of Rouen, Moriuht and sadistic games: A conjecture", Maia, 58, 2006, p. 324-326.

McKitterick, Rosamond, The Frankish Kingdoms under the Carolingians, 751-987, London - New York, Longman, 1983.

MÉGIER, Elisabeth, “Diuina pagina and the narration of history in Orderic Vitalis' Historia ecclesiastica", in Elisabeth MÉGIER, Christliche Weltgeschichte im 12. Jahrhundert: Themen, Variationen und Kontraste. Untersuchungen zu Hugo von Fleury, Ordericus Vitalis und Otto von Freising, Guy LobRichon (praef.), Frankfurt a.M. - New York Bern, P. Lang (Beihefte zur Mediaevistik: Monographien, Editionen, Sammeibande, 13), 2010, p. 283-299.

Montclos, Jean de, Lanfranc et Bérenger. La controverse eucharistique du XI siècle, Leuven, Spicilegium Sacrum Lovaniense (Études et Documents, 37), 1971.

Montclos, Jean de, Lanfranc et Bérenger: les origines de la doctrine de la Transsubstantiation, in Lanfranco di Pavia e l'Europa, 1993, p. 297-326.

Moolenbroek, Jaap van, Vital l'ermite, prédicateur itinérant, fondateur de l'abbaye normande de Savigny, Anne-Marie NАмвот (trad.), Assen - Maastricht, Van Gorcum, 1990.

Moos, Peter von, Hildebert von Lavardin 1056-1133. Humanitas an der Schwelle des Höfischen Zeitalters, Stuttgart, Hiersemann (Pariser historische Studien, 3), 1965.

Morel, Walter, “À propos de la vie métrique de saint Gommaire”, Latomus, 4, 1940, p. 51-61.

Mosetti Casaretto, Francesco, “Baldericus Burgulianus abb.”, in C.A.L.M.A., vol. I/5, 2003, p. 569-571.

Mozley, John Henry, "The collection of medieval latin verse in MS Cotton Titus D. xxiv", Medium Aevum, 11, 1942, p. 1-45. 
Musset, Lucien, "Le satiriste Garnier de Rouen et son milieu", Revue du Moyen Âge latin, 10, 1954, p. 237-266.

Musset, Lucien, "Recherches sur les pèlerins et les pèlerinages en Normandie jusqu'à la première croisade", Annales de Normandie, 12, 1962, p. 127-150.

Musset, Lucien, "Rouen et l'Angleterre vers l'an mil. Du nouveau sur le satiriste Garnier et l'école littéraire de Rouen au temps de Richard II", Annales de Normandie, 24, 1974, p. 287-29o [reimpr. in Musset, "Nordica et Normannica". Recueil d'études sur la Scandinavie ancienne et médiévale, les expéditions des Vikings et la fondation de la Normandie, Paris, Société des Études Nordiques, 1997, p. 467-471].

Musset, Lucien, "L’horizon géographique, moral et intellectuel d'Ordéric Vital, historien anglo-normand", in La chronique et l'histoire au Moyen Âge. Colloque des 24 et 25 mai 1982, Daniel Poirion (ed.), Paris, Presses de l'Université de Paris-Sorbonne (Cultures et civilisations médiévales, 2), 1984, p. 102-122.

Neininger, Falko, “Belmeis, Richard de (d. 1162)", in Oxford Dictionary, 2004, vol. V, p. 36 .

Nicholl, Donald, Thurstan, Archbishop of York, 1114-1140, York, Stonegate Press, 1964.

Nocentini, Silvia, "Fulbertus Sancti Audoeni Rotomagensis monachus", in C.A.L.M.A., vol. III/5, 2011, p. 597.

Norton, Christopher, Archbishop Thomas of Bayeux and the Norman Cathedral at York, York, Borthwick Institute of Historical Research, University of York (Borthwick papers, 100), 2001.

O’Brien O'Keeffe, Katherine, “Edith's choice”, in Latin Learning and English Lore. Studies in Anglo-Saxon Literature for Michael Lapidge, Katherine O'Brien O'Keeffe and Andy Orchard (eds), vol. II, Toronto - Buffalo, NY - London, University of Toronto Press (Toronto Old English Series, 14), 2005, p. 253-274.

O'Brien O'Keeffe, Katherine, Stealing Obedience. Narratives of Agency and Identity in Later Anglo-Saxon England, Toronto, University of Toronto Press (Toronto Anglo-Saxon series, 11), 2012.

ÖBERG, Jan, "Gastgelehrter als literarische Zielscheibe um das Jahr 10oo: Die Invektive Warners von Rouen gegen der Iren Moriuht", Mittellateinisches Jahrbuch, 33/3, 1998, p. 21-43.

OldonI, Massimo, "Mentalità ed evoluzione della storiografia normanna fra XI e XII secolo in Italia", in Ruggero il gran conte e l'inizio dello stato normanno. Giornate normanno-sveve: Bari, maggio 1975, Roma, Centro di Ricerca (Fonti e studi del Corpus membranarum Italicarum, 12), 1977.

OLdoni, Massimo, "L'ignoto Liber Maronis medievale tradotto dall'antico", in Lectures médiévales, 1985, p. 357-374.

Olleris, Alexandre, Lettre sur Fulcoie, archidiacre de Beauvais, Paris, Dondey-Dupré, 1842 .

Omont, Henri, "Satire de Garnier de Rouen contre le poète Moriuht ( $\mathrm{X}^{\mathrm{e}}-\mathrm{XI}^{\mathrm{e}}$ siècle)", Annuaire-Bulletin de la Société de l'histoire de France, 31, no. 2, 1894, p. 193-210.

Omont, Henri, "Épitaphes métriques en l'honneur de différents personnages du XI" siècle composées par Foulcoie de Beauvais, archidiacre de Meaux", in Mélanges Julien Havet. Recueil de travaux d'érudition dédiés à la mémoire de Julien Havet (1853-1893), Paris, E. Leroux, 1895, p. 211-236. 
Orlandi, Giovanni, review of Morton and Muntz, 1972, Studi Medievali, 13, 1972, p. 196-222 [reimpr. in ORLANDI, 2008, p. 547-578].

Orlandi, Giovanni, review of Theobaldi, Physiologus, P.T. Eden (ed. and trad.), Leiden - Köln, E.J. Brill (Mittellateinische Studien und Texte, 6), 1972, in Studi medievali, 14, 1973, p. 902-922 [reimpr. in ORLANDI, 2008, p. 579-603].

Orlandi, Giovanni, “Doppia redazione nei Carmina minora di Ildeberto?”, Studi medievali, 15, 1974, p. 1019-1049 [reimpr. in OrLANDI, 2008, p. 605-634].

Orlandi, Giovanni, "Some afterthoughts on the Carmen de Hastingae Proelio", in "Media latinitas": a collection of essays to mark the occasion of the retirement of L.J. Engels, International conference held in Groningen on April 25-26, 1994, Renée I.A. Nip, Hans Van Dijk, Elizabeth M.C. van Houts, Cornelius Kneepkens, George A.A. KortekaAs (eds), Steenbrugis - Turnhout, in Abbatia S. Petri Brepols (Instrumenta patristica, 28), 1996, p. 117-127 [reimpr. in ORLANDI, 2008, p. 839-850].

OrLANDI, Giovanni, "Ildeberto di Lavardin”, in Orazio. Enciclopedia oraziana, Roma, Istituto della Enciclopedia Italiana [3 vols., 1996-1998], vol. II, 1997, p. 289-291.

Orlandi, Giovanni, Scritti di filologia mediolatina, Paolo ChIEsA, Anna Maria FAGnoni, Rossana E. Guglielmetti and Giovanni Paolo Maggioni (eds), Firenze, SISMEL Edizioni del Galluzzo (Millennio Medievale, 77. Strumenti e Studi. Nuova Serie, 19), 2008.

Ortenberg, Veronica, The English Church and the Continent in the Tenth and Eleventh Centuries: Cultural, Spiritual and Artistic Exchanges, Oxford, Clarendon Press, 1992.

Owen, Douglas David Roy, “The epic and history: Chanson de Roland and Carmen de Hastingae proelio", Medium Aevum, 51, 1982, p. 18-35.

Oxford Dictionary of National Biography, H.G.C. MATTHEw and Brian H. HARRIson (eds), Oxford, Oxford University Press, 2004, 62 vols.

Pagano, Antonio, Il poema "Gesta Roberti Wiscardi” di Guglielmo Pugliese, Napoli, S. Morano, 1909 [reimpr. in PAgANo, Antonio, Studi di letteratura latina medievale, Nicotera, Istituto editoriale calabrese, 1931, p. 1-129].

PARISSE, Michel, “Un voyage en Lorraine: le rouleau des morts de Saint-Pierremont”, Les Cahiers lorrains, 1, 2, 2007, p. 16-27.

Pasquier, Henri, Un poète chrétien à la fin du XI siècle: Baudri, Abbé de Bourgeuil, Archevêque de Dol, d'après des documents inédits, 1046-113o, Paris - Angers, E. Thorin - Lachèse et Dolbeau, 1878.

Pellerin, Henri, “L'œuvre d'Orderic Vital: ses différentes éditions et traductions”, Le Pays d'Auge, 24, 11, 1974a, p. 13-20.

Pellerin, Henri, “Orderic Vital, moine de Saint-Évroult et historien normand”, Le Pays d'Auge, 24, 8, 1974b, p. 5-13.

Peters-Custot, Annick, Bruno en Calabre. Histoire d'une fondation monastique dans l'Italie normande: S. Maria de Turri et S. Stephano del Bosco, Rome, École française de Rome, 2014.

Pommeraye, Jean-François, Histoire de l'abbaye royale de S. Ouen de Rouen divisée en cinq livres, Rouen, R. Lallemant, 1662. 
Pugh, Tison, "Personae, same-sex desire, and salvation in the poetry of Marbod of Rennes, Baudri of Bourgueil, and Hildebert of Lavardin", Comitatus, 31, 2000, p. 57-84.

Raby, Frederic James Edward, A History of Christian Latin Poetry from the Beginnings to the Close of the Middle Ages, Oxford, Clarendon Press, 1927.

Raby, Frederic James Edward, A History of Secular Latin Poetry in the Middle Ages, Oxford, Clarendon Press, 1934, 2 vols.

RADDING, Charles Michael, "The geography of learning in early eleventh-century Europe: Lanfranc of Bec and Berengar of Tours revisited", Bullettino dell'Istituto storico italiano per il medioevo e Archivio Muratoriano, 98, 1992, p. 144-172.

RaIne, James, The Priory of Hexham, Its Chroniclers, Endowments, and Annals, vol. I, Durham, Andrews (Publications of the Surtees Society, 44), 1864.

Ravier, André, Saint Bruno: le premier des ermites de Chartreuse, Paris, Lethielleux, 1967.

Razzoli, Maria Teresa, Le epistole metriche di Baldericus Burguliensis. Dal codice vaticano latino 1351, Roma, Società Dante Alighieri, 1936.

Rico, Francisco, "Tradición y experimento en la poesia medieval: Ruodlieb, Semiramis, Abelardo, Santa Hildegarda”, Romance Philology, 26, 1973, p. 673-689.

Ridyard, Susan Janet, The Royal Saints of Anglo-Saxon England. A Study of West Saxon and East Anglian Cults, Cambridge, Cambridge University Press (Cambridge Studies in Medieval Life and Thought. Fourth Series, 9), 1988.

RIGG, Arthur George, “Henry of Huntingdon's metrical experiments”, Journal of Medieval Latin, 1, 1991, p. 60-72.

Rigg, Arthur George, A History of Anglo-Latin Literature, 1066-1422, Cambridge, Cambridge University Press, 1992.

RigG, Arthur George, “Henry of Huntingdon's herbal”, Mediaeval Studies, 65, 2003, p. 213-292.

RIGG, Arthur George, “Canterbury, Reginald of (fl. c. 1100-c. 1109)”, in Oxford Dictionary, 2004a, vol. IX, p. 950.

RIGG, Arthur George, "Winchester, Godfrey of (b. before 1055, d. 1107)", in Oxford Dictionary, 2004b, vol. LIX, p. 688-689.

Robinson, Joseph Armitage, Gilbert Crispin, Abbot of Westminster, Cambridge, Cambridge University Press (Notes and Documents Relating to Westminster Abbey, 3), 1911.

RoncA, Umberto, Cultura medioevale e poesia latina d'Italia nei secoli XI e XII, Roma, La Società Laziale Editrice, 1892, 2 vols.

Roscini, Filippo, Guglielmo Appulo, monaco giovinazzese del secolo Mille e autore del poema latino sulle Geste di Roberto il Guiscardo, Giovinazzo, s.n., 1967.

Rossi, Agostino, Della patria di Guglielmo detto Apulo, Padova, Prosperini, 1904.

Rubenstein, Jay, "The life and writings of Osbern of Canterbury”, in Canterbury and the Norman Conquest: Churches, Saints and Scholars, 1066-1109, Richard EALES and Richard Sharpe (eds), London - Rio Grande, OH, Hambledon Press, 1995.

Ruppel, Bernd, "Ein verschollenes Gedicht des 12. Jh.: Heinrichs von Huntingdon De herbis", Frühmittelalterliche Studien, 31, 1997, p. 197-213. 
RüTHER, Josef, Der heilige Bruno von Köln, der Kartäuser, Meitingen, Christkönigsverlag vom Weißen Kreuz (Lebensschule der Gottesfreunde, 22), 1936.

Saint Bruno en Chartreuse, Journée d'études à l'Hôtellerie de la Grande Chartreuse, le 3 octobre 2002, Alain René Girard, Daniel Le Blévec and Pierrette PARAvy (eds), Salzburg, Institut für Anglistik und Amerikanistik, Universität Salzburg (Analecta Cartusiana, 192), 2004.

San Bruno di Colonia: un eremita tra Oriente e Occidente, Pietro De Leo (ed.), Claudio Leonardi and Cosimo Damiano Fonseca (praef.), Soveria Mannelli (Catanzaro), Rubbettino, 2004.

San Bruno e la Certosa di Calabria. Atti del Convegno internazionale di studi per il IX centenario della Certosa di Serra S. Bruno (Squillace, Serra S. Bruno 15/18 sett. 1991), Pietro De Leo (ed.), Soveria Mannelli (Catanzaro), Rubbettino, 1995.

SAYERs, William, "The Jongleur Taillefer at Hastings: Antecedents and Literary Fate”, Viator, 14, 1983, p. 77-88.

SChaller, Dieter, "La poesia epica", in Lo spazio letterario del Medioevo I Il Medioevo latino 1 La produzione del testo 2, Guglielmo Cavallo, Claudio Leonardi and Enrico Menestò (eds), Roma, Salerno, 1993, p. 9-41.

SCHALler, Dieter and KöNSGen, Ewald, Initia carminum Latinorum saeculo undecimo antiquiorum. Bibliographisches Repertorium für die lateinische Dichtung der Antike und des früheren Mittelalters, John Tagliabue (adiuv.), Göttingen, Vandenhoeck \& Ruprecht (Carmina medii aevi posterioris latina, 1), 1977.

SCHміDт, Paul Gerhard, "Elemente der Invektive in lateinischen Mittelalter (Garnier von Rouen, Gunzo und Anselm)", in Angewandte Sprachwissenschaft. Interdisziplinäre Beiträge zur mündlichen Kommunikation, Helma BEHME (ed.), Stuttgart, P. Lang, 1988, p. 193-207.

SCHRÖDER, Bianca-Jeanette, Titel und Text. Zur Entwicklung lateinischer Gedichtüberschriften. Mit Untersuchungen zu lateinischen Buchtiteln, Inhaltsverzeichnissen und anderen Gliederungsmitteln, Berlin - New York, W. de Gruyter (Untersuchungen zur antiken Literatur und Geschichte, 54), 1999.

Schumann, Otto, "Baudri von Bourgueil als Dichter", in Studien zur lateinischen Dichtung des Mittelalters. Ehrengabe für Karl Strecker zum 4. September 1931, Walter Stach and Hans Walther (eds), Dresden, Baensch-Stiftung (Schriftenreihe zur Historischen Vierteljahrschrift, 1), 1931, p. 158-170.

Scivoletto, Nino, Spiritualità medioevale e tradizione scolastica nel secolo XII in Francia, Napoli, Armanni (Biblioteca del Giornale italiano di filologia, 2), 1954.

Scoтt, Alexander Brian, “The poems of Hildebert of Le Mans: A new examination of the canon", Mediaeval and Renaissance Studies, 6, 1968, p. 42-83.

Sesto Yagüe, Lucía, “Tradición cesarista y tradición eneádica en la poesía de corte anglonormanda en la Baja Edad Media”, Troianalexandrina, 12, 2012, p. 63-88.

Sharpe, Richard, “Two contemporary poems on Saint Anselm attributed to William of Chester", Revue bénédictine, 95, 1985, p. 266-279.

SHARPE, Richard, A Handlist of the Latin Writers of Great Britain and Ireland before 1540, with Additions and Corrections, Turnhout, Brepols (Publications of the Journal of Medieval Latin, 1), 2001². 
SigNORI, Gabriela, "Muriel und die anderen... oder Gedichte als Freundschaftspfand", in "Meine in Gott geliebte Freundin". Freundschaftsdokumente aus klösterlichen und humanistischen Schreibstuben, Gabriela SignORI (ed.), Bielefeld, Verlag für Regionalgeschichte (Religion in der Geschichte, 4), 1995, p. 67-77 [English translation: Signori, "Muriel and the Others... or Poems as Pledges of Friendship", in Friendship in Medieval Europe, Julian P. Haseldine (ed.), Stroud, Sutton, 1999, p. 199-212].

Silvestre, Hubert, "La controverse Bérenger de Tours-Lanfranc du Bec. À propos d'un livre récent”, Revue belge de philologie et d'histoire, 51, 1973, p. 840-847.

Southern, Richard William, "St Anselm and his English pupils", Medieval and Renaissance Studies, 1, 1943a, p. 3-34.

SOUTHERn, Richard William, "The first Life of Edward the Confessor", English Historical Review, 58, 1943b, p. 385-400.

Southern, Richard William, "St Anselm and G. Crispin, abbot of Westminster", Mediaeval Studies, 3, 1954, p. 78-114.

Southern, Richard William, “The Canterbury forgeries”, English Historical Review, 73, 1958, p. 193-226.

SOUTHERn, Richard William, “The place of Henry I in English history", Proceedings of the British Academy, 48, 1962, p. 127-169.

SOUTHERn, Richard William, Saint Anselm and his Biographer: a study of monastic life and thought, 1059-c. 1130, Cambridge, Cambridge University Press (The Birkbeck lectures), 1963.

Southern, Richard William, Medieval Humanism and Other Studies, Oxford, B. Blackwell, 1970.

Southern, Richard William, Saint Anselm. A Portrait in a Landscape, Cambridge, Cambridge University Press, 1990.

SpeAr, David, “William Bona Anima, abbot of St. Stephen's of Caen, 1070-79”, Haskins Society Journal, 1, 1989, p. 51-6o.

SpEAR, David, "The school of Caen revisited”, Haskins Society Journal, 4, 1992, p. 55-66.

St Dunstan: His Life, Times and Cult, Ramsay Nigel L., Sparks Margaret J. and Tatton-Brown Tim W.T. (eds), Woodbridge, Boydell Press, 1992.

STAFford, Pauline, "Women and the Norman Conquest", Transactions of the Royal Historical Society, Sixth Series, 4, 1994, p. 221-249.

STEInen, Wolfram von den, "Humanismus um 1100", Archiv fur Kulturgeschichte, 46, 1964, p. 1-20 [reimpr. in STEInen, Menschen im Mittelalter, Peter von Moos (ed.), Bern, Francke, 1967, p. 194-214].

STEINEN, Wolfram von den, "Les sujets d'inspiration chez les poètes latins du XII siècle", Cahiers de civilisation médiévale, 9, 1966, p. 165-175, 363-383.

Stella, Francesco, "Poesia latina della Puglia altomedievale: sondaggi intertestuali e rapporti interculturali in epigrafi, agiografie e nei Gesta Roberti Wiscardi", in Bizantini, Longobardi e Arabi in Puglia nell'Alto Medioevo. Atti del XX Congresso internazionale di studio sull'alto medioevo (Savelletri di Fasano, 3-6 novembre 2011), Spoleto (Perugia), Centro Italiano di Studi sull'Alto Medioevo (Atti dei congressi / Centro italiano di studi sull'alto Medioevo, 20), 2012, p. 455-486. 
Stenton, Frank Merry, William the Conqueror and the Rule of the Normans, New York, G.P. Puttnam's Sons, 1908.

Stevenson, Jane, “Anglo-Latin Women Poets”, in Latin Learning and English Lore: Studies in Anglo-Saxon Literature for Michael Lapidge, Katherine O'Brien O'Keeffe and Andy Orchard (eds), vol. II, Toronto, University of Toronto Press (Toronto Old English series, 14), 2005, p. 86-107.

Stolz, Anselm, Anselm von Canterbury. Sein Leben, seine Bedeutung, seine Hauptwerke, München, Kösel-Pustet (Gestalten des christlichen Abendlandes, 1), 1937.

Stoppacci, Patrizia, “Guillelmus Malmesberiensis monachus”, in C.A.L.M.A., vol. V/1, 2015, p. 8o-88.

Strickland, Agnes, Lives of the Queens of Scotland and English Princesses, Connected with the Regal Succession of Great Britain, Elisabeth STRICKLAND (adiuv.), vol. I, Edimburgh - London, W. Blackwood and Sons, 1850.

Szövérffy, Josef, Die Annalen der lateinischen Hymnendichtung, vol. II, Berlin, E. Schmidt (Die lyrische Dichtung des Mittelalters), 1965.

Szövérffy, Joseph, Secular Latin Lyrics and Minor Poetic Forms of the Middle Ages. A Historical Survey and Literary Repertory, from the Tenth to the Late Fifteenth Century, Concord, NH, Classical Folia (Medieval Classics: Texts and Studies), 1992-1995, 4 vols.

Tateo, Francesco, "Le allocuzioni del potere pubblico", in Strumenti, tempi e luoghi di comunicazione nel Mezzogiorno normanno-svevo. Atti delle undecime giornate normanno-sveve. Bari, 26-29 ottobre 1993, Giosuè MuscA and Vito Sivo (eds), Bari, Dedalo (Atti del Centro di studi normanno-svevi, Università degli studi di Bari, 11), 1995, p. 153-165.

Tatlock, John Strong Perry, "Muriel, the earliest English poetess”, Publications of the Modern Languages Association, 48, 1933a, p. 317-321.

TAтLOCK, John Strong Perry, “The English journey of the Laon canons”, Speculum, 8, 1933b, p. 454-465.

TAYLOR, John, Medieval Historical Writing in Yorkshire, York, St Anthony's Press, 1961.

Thompson, Kathleen, “The Norman aristocracy before 1066. The Example of the Montgomerys", Historical Research, 60, 1987, p. 251-263.

Thompson, Kathleen, "Robert [called Robert Curthose], Duke of Normandy (b. in or after 1050, d. 1134)", in Oxford Dictionary, 2004, vol. XLVII, p. 86-92.

Thomson, Rodney Malcolm, "William of Malmesbury as historian and man of letters", Journal of Ecclesiastical History, 29, 1978, p. 387-413.

Thomson, Rodney Malcolm, William of Malmesbury, Woodbridge, Boydell Press, 1987.

Thurot, Charles, "Études critiques sur les historiens de la première croisade: Baudri de Bourgueil", Revue historique, 1, 1876, p. 373-386.

Tilliette, Jean-Yves, "Culture classique et humanisme monastique: Les Poèmes de Baudri de Bourgueil”, in La littérature angevine médiévale. Actes du colloque du samedi 22 mars 1980, publiés par le Centre de recherche de littérature et de linguistique sur l'Anjou et les Bocages de l'Université d'Angers, Maulévrier, H. Champion, 1981a, p. 77-88. 
Tilliette, Jean-Yves, "La chambre de la comtesse Adèle: savoir scientifique et technique littéraire dans le c. CXCVI de Baudri de Bourgueil", Romania, 102, 1981b, p. 145-171.

Tilliette, Jean-Yves, “Insula me genuit. L'influence de l'Enéide sur l'épopée latine du XII ${ }^{\mathrm{e}}$ siècle”, in Lectures médiévales, 1985, p. 121-142.

Tilliette, Jean-Yves, "Hermès amoureux, ou les métamorphoses de la Chimère. Réflexions sur les carmina 200 et 201 de Baudri de Bourgueil”, Mélanges de l'École Française de Rome. Moyen Âge - Temps modernes, 104, 1992a, p. 121-161.

Tilliette, Jean-Yves, “Marbode”, in Dictionnaire des Lettres Françaises. Le Moyen Âge, Paris, Librairie Générale Française, 1992b, p. 982-983.

Tilliette, Jean-Yves, "Savants et poètes du Moyen Âge face à Ovide: les débuts de l'aetas ovidiana", in "Ovidius redivivus". Von Ovid zu Dante, Michelangelo Picone and Bernhard ZimmermanN (eds), Stuttgart, M \& P Verlag für Wissenschaft und Forschung, 1994, p. 63-104.

Tilliette, Jean-Yves, “Le retour d'Orphée. Réflexions sur la place de Godefroid de Reims dans l'histoire littéraire du XI ${ }^{\mathrm{e}}$ siècle", in Latin Culture in the Eleventh Century, 2002, vol. II, p. 449-463.

Tilliette, Jean-Yves, “Garnerius Rotomagensis monacus”, in C.A.L.M.A., vol. IV/1, 2012, p. 55-56.

Tomea, Paolo, “Le 'sconfitte' dell'Arcangelo. Tre passi da Vita Ansuini BHL 555, Miracula Audoeni BHL 760 e Vita Geraldi BHL 3417", Aevum, 84, 2010, p. 475484.

Toubert, Pierre, "La première historiographie de la conquête normande de l'Italie méridionale (XI siècle)", in I caratteri originari della conquista normanna. Diversità e identità nel Mezzogiorno (1030-1130). Atti delle sedicesime giornate normannosveve. Bari, 5-8 ottobre 2004, Raffaele Licinio and Francesco Violante (eds), Bari, Dedalo (Atti del Centro di studi normanno-svevi, Università degli studi di Bari, 16) 2006, p. 15-49.

Tramontana, Salvatore, "I luoghi della produzione storiografica", in Centri di produzione della cultura nel Mezzogiorno normanno-svevo, Aldo Cossu (praef.), Bari, Dedalo (Atti del Centro di studi normanno-svevi. Università degli studi di Bari, 12), 1997, p. 21-40.

TyLER, Elizabeth M., England in Europe. English Royal Women and Literary Patronage, c. 1000-c. 1150, Toronto, University of Toronto Press (Toronto Anglo-Saxon series, 23), 2017.

UgÉ, Karine, Creating the Monastic Past in Medieval Flanders, York - Woodbridge, York Medieval Press - Boydell Press, 2005.

Vallat, Daniel, "Les épigrammes attribuées à Martial”, Latomus, 67, 2008, p. 949-976.

VAn Houts, Elisabeth Maria Cornelia, “The Ship List of William the Conqueror", in Anglo-Norman Studies X Proceedings of the Battle Conference 1987, Reginald Allen Brown (ed.), Woodbridge, Boydell Press, 1988, p. 159-183.

VAn Houts, Elisabeth Maria Cornelia, "Latin poetry and the Anglo-Norman court 10661135: The Carmen de Hastingae Proelio", Journal of Medieval History, 15, 1989, p. 39-62. 
VAN Houts, Elisabeth Maria Cornelia, "A note on Jezebel and Semiramis, two Latin Norman poems from the early eleventh century", Journal of Medieval Latin, 2, 1992, p. 18-24.

VAn Houts, Elisabeth Maria Cornelia, “L'oralité dans l'hagiographie normande aux $\mathrm{XI}^{\mathrm{e}}$ et $\mathrm{XII}^{\mathrm{e}}$ siècles. La valeur des témoignages oculaires des femmes dans les miracula", in Les saints dans la Normandie médiévale. Colloque de Cerisy-la-Salle (26-29 septembre 1996), Pierre Boukt and François Neveux (eds), Caen, Presses universitaires de Caen, 200o, p. 83-94.

Van Houts, Elisabeth Maria Cornelia, "Matilda (d. 1083)", in Oxford Dictionary, 2004, vol. XXXVII, p. 318-320.

Van Houts, Elisabeth Maria Cornelia, "Contrasts and interaction. Neighbours of nascent Dutch writing: The English, Normans and Flemish (c. 1000-c. 1200)", Queeste, 13, 2006a, p. 3-11.

VAN Houts, Elisabeth Maria Cornelia, "The Flemish contribution to biographical writing in England in the eleventh century", in Writing Medieval Biography 750-1250. Essays in Honour of Professor Frank Barlow, David R. BATES, Julia C. CRICK and Sarah L. Hamilton (eds), Woodbridge, Boydell Press, 2006b, p. 111-127.

VAN Houts Elisabeth Maria Cornelia, “The fate of priests' sons in Normandy with special reference to Serlo of Bayeux", Haskins Society Journal, 25, 2013, p. 57-106.

VAn Houts, Elisabeth Maria Cornelia, "Serlo of Bayeux and England”, Tabularia [On line], Autour de Serlon de Bayeux: la poésie normande aux XI ${ }^{e}-X I I^{e}$ siècles. On line: 12 july 2016. URL: http://journals.openedition.org/tabularia/26oo, p. 139-155.

VANNi Rovighi, Sofia, Introduzione a Anselmo d'Aosta, Roma-Bari, Laterza (I Filosofi, 46), 1987.

Vermigli, Francesco, "Brunus Carthusianorum institutor", in C.A.L.M.A., vol. II/4, 2007, p. 503-504.

Voss, Lena, Heinrich von Blois, Bischof von Winchester (1129-1171), Berlin, Ebering (Historische Studien, 210), 1932.

WAdDell, Helen, The Wandering Scholars, London, Constable, 1927.

WAGner, Fritz, "Das Alexiusgedicht des Brüsseler Codex Nr. 8883-94”, in Festschrift für Ingeborg Schröbler zum 65. Geburtstag, Dietrich Sснмідтке and Helga Schüppert (eds), Tübingen, Niemeyer (Beiträge zur Geschichte der deutschen Sprache und Literatur, 95. Sonderheft), 1973, p. 144-169.

WALther, Hans, Initia carminum ac versuum medii aevi posterioris Latinorum. Alphabetisches Verzeichnis der Versanfänge mittellateinischer Dichtungen, Göttingen, Vandenhoeck \& Ruprecht (Carmina Medii Aevi Posterioris Latina, I/1), 1959.

Watkins, Priscilla D., "Lanfranc at Caen: teaching by example", in Teaching and Learning in Northern Europe, 1000-1200, Sally N. VAUGHN and Jay RubENSTEIN (eds), Turnhout, Brepols (Studies in the early Middle Ages, 8), 2006, p. 71-97.

Wattenвach, Wilhelm, "Lateinische Gedichte aus Frankreich im elften Jahrhundert”, Sitzungsberichte der K. Preussischen Akademie der Wissenschaften zu Berlin, 7, 1891, p. 97-114.

Webber, Teresa, "Script and manuscript production at Christ Church, Canterbury, after the Norman Conquest", in Canterbury and the Norman Conquest. Churches, Saints and Scholars 1066-1109, Richard EALES and Richard SHARPE (eds), London Rio Grande, OH, Hambledon Press, 1995, p. 145-158. 
White, Geoffrey H., "The first house of Bellême", Transactions of the Royal Historical Society, Fourth Series, 22, 1940, p. 67-99.

Williams, George H., The Norman Anonymous of 1100 A.D., Cambridge, MA, Harvard University Press (Harvard Theological Studies, 18), 1951.

Williams, John R., "Godfrey of Rheims, a humanist of the eleventh century”, Speculum, 22, 1947, p. 29-45.

WiLliams, John R., “The cathedral school of Rheims in the eleventh century", Speculum, 29, 1954, p. 661-667.

Williams, Roger, "Über die Quellen der Gesta Roberti Wiscardi des Guillermus Apuliensis”, Archiv der Gesellschaft für Ältere Deutsche Geschichtskunde, 10, 1849, p. 87-130.

Wilmart, André, "L'élégie d'Hildebert pour Muriel”, Revue Bénédictine, 49, 1937, p. $376-384$

Wilmart, André, "La légende de Ste Edith en prose et vers par le moine Goscelin", Analecta Bollandiana, 56, 1938, p. 5-101, 265-307.

Winterbotтom, Michael, "William of Malmesbury versificus", in Anglo-Latin and Its Heritage. Essays in Honour of A.G. Rigg on His 64th Birthday, Siân EcHARD and Gernot Rudolf Wieland (eds), David Townsend (praef.), Turnhout, Brepols (Publications of the Journal of Medieval Latin, 4), 2001, p. 109-127.

Winterbotтом, Michael, "William of Malmesbury and the Normans", Journal of Medieval Latin, 20, 2010, p. 70-77.

Wolf, Kenneth Baxter, Making History: The Normans and their historians in eleventhcentury Italy, Philadelphia, PA, University of Pennsylvania Press (Middle Ages Series), 1995.

Wolff, Etienne, La Lettre d'amour au Moyen Âge, Paris, NiL (Le cabinet de curiosités), 1996.

Wolterbeek, Marc, Comic Tales of the Middle Ages. An Anthology and Commentary, New York - Westport, CT - London, Greenwood Press (Contributions to the study of world literature, 39), 1991.

Wright, Neil, “The place of Henry of Huntingdon's Epistola ad Warinum in the text history of Geoffrey of Monmouth's Historia regum Britanniae: A preliminary investigation", in France and the British Isles in the Middle Ages and Renaissance. Essays by Members of Girton College of Cambridge in Memory of Ruth Morgan, Gillian Jondorf and David Norman Dumville (eds), Woodbridge, Boydell Press, 1991a, p. 71-113.

Wright, Neil, "William of Malmesbury and latin poetry. Further evidence for a Benedictine's reading", Revue bénédictine, 101, 1991b, p. 122-153.

Wright, Nigel, “Industriae testimonium: William of Malmesbury and Latin poetry revisited”, Revue bénédictine, 103, 1993, p. 482-531.

WRIGHT, Thomas, Biographia Britannica Literaria, or Biography of Literary Characters of Great Britain and Ireland, Arranged in Chronological Order. Anglo-Norman Period, vol. II, London, J.W. Parker, 1846.

Wright, Michael and Loncar, Kathleen, "Goscelin's legend of Edith", in Writing the Wilton Women, 2004, p. 21-93. 
Writing the Wilton Women. Goscelin's Legend of Edith and Liber confortatorius, Stephanie Hollis (ed.), William Reginald Barnes, Rebecca Hayward, Kathleen LonCAR and Michael Wright (adiuv.), Turnhout, Brepols (Medieval Women, 9), 2004.

YoRke, Barbara A.E., “The legitimacy of St. Edith”, The Haskins Society Journal, 11, 2003, p. 97-113.

Zumthor, Paul, Guillaume le Conquérant et la civilisation de son temps, Paris, Hachette, 1964. 